\title{
Anmeldelser
}

Henrik Fangel: Haderslev bys historle 1800-1945, bind 1.

Haderslev 1975. 574 sider. Ill.

Haderslev er den eneste af de nordslesvigske købstæder, der ikke ejer en sammenhængende byhistorie. Tiden før 1800 er behandlet $i$ Th. A. Achelis' artikelsamling "Haderslev i gamle dage«, der udkom 192629, men først med udsendelsen af Henrik Fangels fremstilling af Haderslevs historie i tidsrummet fra 1800 til $1864 / 70$ er den lange savnede fortsættelse af Achelis' skildring blevet forelagt publikum.

Bogen er udgivet af Haderslev bank som et jubilæumsskrift $i$ anledning af bankens 100 års fødselsdag. Takket vxre bankens gavmildhed har værket fået et prægtigt udstyr og forfatteren haft mulighed for gennem to år at bruge størstedelen af sin tid til udarbejdelsen.

Bogen er frugten af en imponerende arbejdspræstation. Herom vidner dens omfang, den store mængde af trykte og utrykte kilder, som fremstillingen hviler på, og de statistiske analyser, der tilsammen udgar et grundelement $\mathrm{i}$ den historiske undersøgelse. Det lader sig imidlertid ikke benægte, at den detailrigdom, der er tilstræbt, er gået ud over overskueligheden. Især i det sociale og okonomiske afsnit med de mange tabeller er det ikke let at tilegne sig indholdet. Følgende eksempel fra s. 18-19 er desværre typisk: For at sætte sig ind i befolkningstilvaksten skal man fordybe sig $i$ en ganske kompliceret tabel, der ledsages af udførlige kildehenvisninger, læse en kommenterende underskrift til tabellen og kombinere alt dette med bogens lobende tekst. Bogens disposition tynges endvidere af lange og grundige tilstandsbeskrivelser. Til denne kategori hører i virkeligheden også det indledende afsnit om hovedtræk af udviklingen 1800-1890 (det går kun til 1860!). Følgen er, at adskillige oplysninger om befolkningsmæssige, sociale og administrative forhold må gentages $i$ senere afsnit. Mon ikke disse formelle ufuldkommenheder skyldes, at forfatteren har måttet aflevere sit manuskript til et bestemt tidspunkt uden at have haft mulighed for en sidste gennemgang? Dette må også være 
forklaringen på, at det $\mathrm{i}$ bankens forord hedder, at fremstillingen er ført frem til 1890, skønt en gennemlæsning viser, at den stopper ved 1864 (1870 for den økonomiske udviklings vedkommende). Det er vel også tidnød, der har bevirket, at bogen ikke er forsynet med et register.

Indholdsmassigt kan bogen deles $\mathrm{i}$ de afsnit, der behandler sociale og økonomiske forhold, og dem, der behandler den politiske og nationale samt kulturelle udvikling.

Forfatterens betydeligste forskningsindsats ligger sikkert på det sociale og økonomiske område. Dér er der med stor flid og grundighed gennemført en bearbejdelse af et valdigt materiale, hentet fra folketallingslister, brandtaksationsprotokeller, skattelister $\mathrm{m}$. m. Pà denne måde er det navnlig blevet muligt at give et langt bedre billede af de lavere klassers liv end det, der kan uddrages af de sparsomme fortællende kilder. Fangel formår ved hjælp af dette tørre materiale at give læseren et levende indtryk af de forskellige sociale lags familie-, bolig-, arbejds- og indtægtsforhold osv. Han dokumenterer bl. a., at $25 \%$ af Haderslevs indbyggere levede godt eller acceptabelt, men ikke mindre end $35 \%$ pà eksistensminimum, og det falder ham ikke ind at betegne de ludfattige gadehandlere som "et pittoresk indslag" $\mathrm{i}$ byens liv (som det hedder i Åbenrå Bys Historie). Af stor interesse er de tabeller, der viser den sociale lagdeling i 1803 og 1835. Alt i alt er det lykkedes forfatteren at give en selvstændig og dybtgående fremstilling af den materielle udvikling i Haderslev.

Afsnittene om den politiske og nationale udvikling fortjener ikke samme ros. Ganske vist bygges der også her på et meget betydeligt kildemateriale, og store dele af fremstillingen og ræsonnementerne er originalt arbejde, men dokumentationen er på dette vanskelige felt ikke så omhyggelig som i fremstillingen af de materielle forhold. Det er således karakteristisk, at forfatteren undlader at gennemføre en analyse af tidens mange petitioner og adresser, skont han selv fortæller, at man på denne måde kunne få oplysninger om de nationale partiers sammensætning, og på s. 442 indrømmes det, at kun fortsatte detailundersøgelser kan godtgøre, om forfatterens sammenstilling af sociale lag og nationale holdninger er holdbare.

Fremstillingen er med held holdt $i$ et lidenskabsløst sprog. Dette kommer navnlig skildringen af perioden fra 1850 til 1864 til gode. Selvom det skulle vise sig, at karakteristikken af de kongerigske embedsmænds lukkede verden er noget ensidig, må det siges, at forfatteren er sluppet ualmindelig heldigt fra sin skildring af dette tidsrum med dets blanding af økonomisk fremgang, politisk reaktion og religiøs vækkelse. - I modsætning hertil virker fremstillingen af de liberale og nationale strømninger i 1840'erne noget farveløs. "Hiort Lorenzen var vel nok den betydeligste personlighed, som byen Haderslev har fostret «, hedder det på side 354, men det er ikke 
et indtryk, man udvinder af Fangels skildring. Billedet af de prominente slesvigholstenere er tilsvarende blegt, og det er vel en følge af denne mangelfulde fordybelse, at overbeviste slesvigholstenere konsekvent kaldes »fanatikere«. Man kunne også ønske sig det statistiske materiale vedrørende ikke-materielle forhold udnyttet med større kritik. Der synes f. eks. ikke at være belæg for, at overklassen i Haderslev skulle have været mere tysktalende end deres standsfæller i andre nordslesvigske byer; i betragtningerne vedrørende sprogforholdene er der åbenbart ikke taget hensyn til, at Haderslev relativt havde langt flere tilflyttere fra Kongeriget end andre sønderjyske byer, og det er forkert uden videre at henregne tilflytterne fra Sydslesvig til de tysktalende. Sidst, men ikke mindst, må man næevne den principielle skavank, at forfatteren ikke har gjort sig indholdet af kategorier som »dansksindet «, "slesvigholstener «, »indifferent « klart. Var "slesvigholstenerne" i Haderslev "tysksindede " eller kun nogle af dem? Var de »separatister «? Kan man sige, at de lavere sociale lag var windifferente«, når det samtidig gøres gxldende, at deres nloyalitet « og »kongetroskab* var et træk af gammel dato, som fik væsentlig betydning for byens stillingtagen i 1848 ?

Disse ufuldkommenheder kan ikke undgå at påvirke den undersøgelse, der er forfatterens egentlige anliggende: at klarlægge, om der er en sammenhæn mellem den sociale og økonomiske udvikling på den ene side og den politiske og nationale på den anden. At forfatteren giver et bekræftende svar på dette spørgsmål kan ikke undre, men det forekommer anmelderen, at svaret i for høj grad holder sig til overfladen, og at læseren svigtes $i$ sine forventninger, når det gælder belysningen af den politiske og nationale udvikling, dvs. netop det, der rummer det interessante og særlige ved Haderslevs historie. Det er ikke blot et sporgsmål om at udnytte kilderne, men endnu mere om at have teoretisk indsigt $\mathrm{i}$ liberalismen og nationalismen. En sådan indsigt fremtræder ikke i Fangels bog. Der gøres ikke rede for de faktorer, der førte til de nationale bevægelsers opståen, for disse bevægelsers karakteristiske træk eller for den betydning, de har haft for den historiske udvikling.

I stedet støder man på det forhastede synspunkt, at de nationale modsætninger må opfattes som camouflerede sociale modsætninger. Men mon dette virkelig udtrykker Fangels opfattelse af de nationale problemer? Mon forklaringen på de påpegede mangler ikke snarere er den, at Fangel i sit imponerende arbejde har måttet forsømme den nationale udvikling, fordi historiens materielle side har lagt beslag på størstedelen af hans kræfter?

Anmelderens kritiske bemærkninger har ikke til hensigt at nedvurdere indholdet i Fangels bog. De skal forstås på baggrund af, at der her foreligger en undersegelse, der, som enhver betydelig forskningsindsats, fremkalder tilslutning og vækker indsigelser, men først 
og fremmest stimulerer til fortsatte videnskabelige drøftelser. Det må ønskes, at Henrik Fangel inden længe må kunne glæde publikum med fortsættelsen af sit store værk om Haderslev bys historie.

G. Japsen

Ingwer Ernst Momsen: Dle allgemeinen Volkszählungen in Schleswig-Holstein in dänischer Zelt (1769-1860) - Geschichte Ihrer Organisation und Ihrer Dokumente.

Karl Wachholz Verlag, Neumünster 1974 (Quellen und Forschungen zur Geschichte Schleswig-Holsteins, Band 66) 218 sider.

Mens central personregistrering og anden data- og kommunikationsteknik i de højt udviklede lande har giort folketællinger overflødige, var sådanne ikke alene uomgængelige for udviklingen af statistisk og demografisk videnskab, men gennemførelsen af regelmæssige folketællinger var også et vigtigt led $i$ udviklingen af en moderne statsadministration.

Først mod slutningen af det attende århundrede magtede myndighederne $\mathrm{i}$ de mere fremskredne lande en sådan opgave. Foregangsland var Sverige, som afholdt den første folketxlling i moderne forstand i 1750 . Nitten år efter blev der med tydelig skelen til det svenske forbillede afholdt en folketælling $i$ det daværende dansk-norske monarki. Vi var endda forholdsvis tidligt fremme. USA havde sin forste folketzlling i 1790, Storbritannien og Frankrig deres første i 1801.

Mens folketællingen 1769 havde omfattet hele monarkiet - altså også Slesvig og de kongelige dele af Holsten, samt Oldenborg, var hertugdømmerne udeladt ved de følgende tællinger i 1787 og 1801 . Den anden txlling her blev forst afholdt 1803, og den tredie fulgte i 1835 året efter, at der var afholdt en folketælling $\mathrm{i}$ kongeriget. Fra 1840 og derefter hvert femte år afholdtes folketælling samtidig i hele den daværende helstat, idet krigsåret 1850 dog danner en undtagelse for hertugdømmernes vedkommende.

Ialt blev der i tidsrummet 1769 til 1860 afholdt syv folketællinger, som omfattede hertugdømmerne Slesvig og Holsten (og fra 1840 Lauenborg). Det er disse syv folketællinger - deres planlægning og udførelse, bearbejdning og udnyttelse, som er emne for dr. Ingwer Momsens disputats fra 1968, som han i noget omarbejdet skikkelse har publiceret i 1974.

Bogen er et stykke administrationshistorie - en skildring af statistikkens og demografiens historie fra pionerstadiet med dets vaklende metodik og logiske brist $\mathrm{i}$ begrebsapparatet og usikkerhed $\mathrm{i}$ sigtet til et udviklingstrin preget af rutine og ekspertise, men også af en vis bundethed til de nu engang etablerede rammer. Emnet er vel- 
afgrænset og afgrænsningen rimelig, fordi tællingerne $\mathrm{i}$ hertugdømmerne foruden at være tysksprogede adskilte sig fra de kongerigske ved en anden procedure - optælling $i$ landdistrikterne ved civilmyndighed i modsætning til den kongerigske optælling ved kirkelig instans - og ved en selvstændig tællingsmyndighed frem til 1840. Fremstillingen, klart og fast komponeret, er centreret $i$ hovedafsnittene omkring txllingerne 1769,1803 og 1835-60 og præget af forfatterens dybe fortrolighed med kildematerialet, både det selve txllingerne har afsat i form af tællingslister og "tabeller «, og den forudgående og sideløbende korrespondance mellem de involverede myndigheder. Her er tale om den velnok mest omfattende, flittigste og nøjagtigste behandling, som kildematerialet og den dermed relevante litteratur har været genstand for $\mathrm{i}$ dette århundrede. Det vidner om forfatterens nidkærhed, at han, som skriver om folketællingerne $i$ hertugdømmerne, ved sit fund af txllingslister fra 1769-tællingen i Helsingør rådstuearkiv, nu $\mathrm{i}$ Landsarkivet for Sjalland, kan påvise et af forskningens hidtil ukendt materiale fra denne folketælling. Rentekammerets direktiver fra denne den første folketælling indeholdt nemlig kun bestemmelse om indsendelse af tallene $\mathrm{i}$ form af "tabellerne " og intet om basismaterialet, listerne med navne på de talte, som den dag idag kendes $\mathrm{i}$ ret stort antal fra lokale embedsarkiver $\mathrm{i}$ hertugdømmerne, men som i kongeriget hidtil kun har været kendt fra tællingen $i$ Horsens købstad. Dr. Momsen nærer optimistisk tiltro til, at yderligere eftersøgning i danske landsarkiver vil bringe mere af den slags materiale for dagen. Selv afstår han naturligvis fra at følge sporet videre.

Emnets afgrænsning og den dermed vundne mulighed for beherskelse af hele det relevante kildemateriale gør det muligt for forfatteren at fremkomme med vigtige korrektiver til tællingernes resultater og især til de domme, der i litteraturen senere er fældet over dem. Dr. Momsen plæederer således overbevisende for, at det i 1769 konstaterede kvindeoverskud, som foruroligede G. C. Oeder og andre samtidige og senere statistikere og historikere, næppe har hidrørt fra tællingsfejl, men snarere har været et permanent led i hertugdømmernes demografi. Forholdet er $\mathrm{i} ø v$ rigt almindeligt i mange lande $\mathrm{i}$ dag. Kvindeoverskuddet var i 1803 halveret i forhold til 1769 og mindskedes siden gradvis. Den påståede sammenhæng mellem dette og de fraværende søfolk og militærpersoner, som udelodes ved tællingen, må ifølge dr. Momsen afvises for hertugdømmernes vedkommende.

Værdifuld er især behandlingen af folketællingernes kildeværdi, hvor forfatteren parrer sin omfattende viden med skønsomhed og kritisk sans. Gennem den interessante sammenligning af folketællingerne og fabriks- og skibsbygningsindberetninger har han således påvist, at et stort antal industrielt beskæftigede særlig under de tidligste 
faser af industrialiseringen i Flensborg, Åbenrå og Haderslev må dølge sig under erhvervsrubrikken "Tagelöhner und Arbeitsleute«. Således var der ifølge værftsindberetningerne i 1840 og i 1860 beskxftiget henved 190 ansatte ved værfterne i Ảbenrå. For det forstnævnte år anfører folketællingen kun seks beskæf tigede med skibsbyggeri, men derimod 256 »Tagelöhner«; for det sidstnæunte år har folketællingen 149 beskæftigede med skibsbyggeri i Ảbenrå og 208 »Tagelöhner«. Man kan måske regne med, at folketællingernes unøjagtighed på dette område mindskedes, men at den bestandig var betydelig. Selv om hensigten med de datidige folketxllinger ikke i første række var erhvervsstatistisk, kan Momsen i modsætning til Ric. Willerslev ikke frakende dem kildeværdi i den henseende, fordi han sondrer mellem håndværksmæssigt og industrielt beskæf tigede, og fordi han i modsxtning til Willerslev ikke lader sig nøje med det offentliggjorte tællingsmateriale.

En overraskende fejlkilde sporer forfatteren i oversætterfejl ved udarbejdelsen af tysksprogede skemaer og vejledninger efter dansk forlæg. Tællingerne foregik indtil 1845 på tysk overalt $\mathrm{i}$ hertugdømmerne. Derefter anvendtes dansksprogede skemaer m. m. i Nordslesvig. En embedsmand i Altona henregnede i 1840 under rubrikken "Gürtler " remmesnidere og sadelmagere - "welche Gürtel machen ", men rettede det, da han erfarede, at gørtlere i København befattede sig med metalstøberi. Erhvervsangivelser som "Möbelhändler og »Glashändler « skabte ligeledes usikkerhed.

Foruden sprogforbistringen antyder forfatteren en kommunikationskløft mellem opgavestillerne - de statistiske eksperter i København - og opgaveløserne - de lokalt placerede embedsmænd, hvis sagkundskab sjxldent gik i statistisk retning, men som bedst muligt søgte at forstå intentionerne bag de stillede spørgsmål. Det er et tilbagevendende tema, som dr. Momsen ikke overspiller. Embedsmændene $\mathrm{i}$ Tabelkontorerne, Tabelkommissionen og i Statistisk Bureau, som de centrale txllingsorganer successivt blev kaldt, udfoldede belært af erfaringerne fra forrige folketællinger store anstrengelser for at forekomme misforstålelser $\mathrm{i}$ den næste. Vejledningerne, der $\mathrm{i}$ 1769 nærmest indskrænkede sig til et forlæg for de skemaer, som amtmænd, biskopper og magistrater skulle lade trykke og fordele $i$ fornødent omfang, voksede med tiden til fire txttrykte foliosider. Men det rokker nxppe ved det faktum, at de centrale txllingsmyndigheder spurgte ud fra en forestillingsverden præget af deres sagkundskab $\mathrm{i}$ statistisk henseende og deres almene københavnske baggrund og ganske åbenbart savnede lokalkendskab til korrekt vurdering af de indkomne besvarelser. Det virker påfaldende, at de ikke foretog en kritisk gennemgang af erhvervsstatistiske oplysninger i folketællingerne, inden txllingsresultater blev publiceret.

Den letlæselige, velafgrænsede og velkomponerede afhandling har 
sin værdi ved den omhyggelige registrering og prøvning af kildematerialet og dets kildeværdi. Det er vundet ved afgrænsningen og dybden $\mathrm{i}$ arbejdet, men efterlader det indtryk hos læseren, at folketællingerne $\mathrm{i}$ hertugdømmerne, og det vil i denne forbindelse også sige i Danmark, så at sige ikke modtog inspiration fra statistikere i andre lande. Det hænger måske sammen med, at forfatteren sporer de fleste impulser til forbedring i metode og teknik til indenlandske kilder - fra G. C. Oeder, som bearbejdede 1767-tællingen til lægen J. R. Hübertz, som gav stadet til, at folketællingerne siden 1845 oplyser personernes fødested - men dog viser Tabelkontorets journal, at det i 1830'erne udvekslede skemaer med statistiske myndigheder i Frankrig og forskellige tyske stater, så man må antage, at døren var åben for inspiration fra udenlandske fagfæller.

En enkelt oplysning er tiden løbet fra. Forfatteren meddeler s. 168 $i$ note 520, at Rigsarkivet agter at udsende en fortegnelse over de slesvigske folketællinger som Vejledende Arkivregistratur bd. 15. Det har muligvis været planlagt sådan; men planen er da ændret. Det 15. bind $\mathrm{i}$ rxkken af Vejledende Arkivregistratur handler ikke om slesvigske folketællinger, og det er usikkert, hvordan og hvornår fortegnelser over folketællingerne i Slesvig og Holsten vil blive publiceret fra Rigsarkivet.

\section{Micbael Hertz}

Dleter Pust: Politische Sozlalgeschlchte der Stadt Flensburg. Untersuchungen zur politlschen Führungsschicht Flensburgs Im 18. und 19. Jahrhundert. Schriften der Gesellschaft für Flensburger Stadtgeschichte 23, Kiel 1975. 365 s.

I de senere år har det flensborgske byhistoriske selskab udfoldet en imponerende udgivelsesvirksomhed, både i omfangs- og kvalitetsmæssig henseende. Blandt selskabets langsigtede planer er udgivelsen af resultaterne af et igangværende forskningsprojekt med socialhistoriske undersøgelser. Den første frugt heraf var Gerhard Kraacks vigtige bog Das Gildewesen der Stadt Flensburg, 1969, og Pusts bog, forfatterens dissertation fra 1974, er den anden.

Pusts arbejde, hvis undertitel er mere pracis end hovedtitlen, er en imponerende arbejdspræstation. Fremstillingen bygger på usædvanlig omfattende kildestudier, og den indeholder en overordentlig fyldig og værdifuld dokumentation, således at noter og bilag er mere omfattende end selve teksten, der er blevet meget tør. En folkelig bog er der altså ikke tale om, trods det spæendende emne og forfatterens ubestridelige kompetance. Det er en meget lang periode, forfatteren har gennemarbejdet, nemlig tiden fra 1730 til 1918/20. I centrum for undersøgelsen står dels det administrationshistoriske spørgsmål om valgordningerne til byrådet og andre dele af byens 
selvforvaltning, dels det dermed sammenhængende spørgsmål om bystyrets rekrutteringsgrundlag, d. v.s. den sociale sammensxtning af byens magthavergruppe. Udviklingen i perioden strækker sig fra den fătallige købmandsklasses oprindelige totale dominans til indførelsen i 1919 af en i moderne forstand demokratisk kommunalforfatning. Et væsentligt formål for forfatteren er at vise forlobet af udviklingen som en gradvis demokratiseringsproces, og de $\mathrm{i}$ realiteten meget små ændringer, der sker før 1919 i retning af udvidelser af valgret og valgbarhed, forsøges ivrigt tolket som stadier i en demokratisk udvikling. Dette synspunkt er nok ikke det mest frugtbare at betragte perioden under, da der hele tiden er tale om, at magten forbliver $i$ hænderne på byens økonomiske overklasse. At købmændenes eneherredømme efterhånden brydes, er vel snarere et tegn på ændringer $i$ den økonomiske dominans i samfundet og ikke en følge af en demokratiseringsvilje i moderne forstand. Pust er da også udmærket klar over, at der skulle en revolution til i Tyskland, før man fik en valgordning, der søgte at stille borgerne lige på det kommunale område. Det er tvivlsomt, om man kan tale om en langsom, logisk demokratiseringsudvikling. Men netop når forfatteren gerne vil belyse demokratiets indtrængen $i$ det kommunale liv, havde det været ønskeligt, om han til trods for bogens titel havde lagt større vægt på tiden efter 1900 , hvor socialdemokraterne begyndte deres kamp for at fă indflydelse på bystyret. Netop socialdemokratiets indsats her behandles overfladisk, hvad Pust også selv gør opmærksom på. Derimod dvæler han meget ved den splittelse $\mathrm{i}$ den borgerlige lejr, der hjalp socialdemokraterne til at fá valgt enkelte medlemmer ind $\mathrm{i}$ byrådet. Med revolutionen 1918 fulgte også i Flensborg som andre steder arbejderog soldaterrådets forsøg på at få indflydelse på bystyret ved at indsætte en såkaldt tilforordnet til at føre kontrol med lokalforvaltningen for kommunalreformen 1919. Men følgerne af denne fornyelse forsøges ikke nærmere analyseret. Kildeforholdene gør det måske også svært. Af avisstof bygger Pust udelukkende på den borgerlige, tysksprogede presse. Lidt længere kunne han nok være kommet ved også at benytte den socialdemokratiske avis, og i øvrigt også Flensborg Avis, for han beskæf tiger sig indimellem også med den dansksindede befolkningsdel og kommunalstyret. Forfatteren kan dog med en vis ret hrvde, at disse spørgsmål falder uden for rammerne af hans fremstilling. Men netop når demokratiseringssynsvinklen er så vigtig for ham, virker det uforståeligt, at han tilsyneladende mister interessen, når egentlige demokratiske bestræbelser begynder at gøre sig gxldende. Man får uvilkårligt det indtryk, at Pusts hjerte befinder sig i købmandsvaldets gode, gamle dage.

I øvrigt betoner Pust som sit formål ikke blot at ville undersøge det snævert forfatningshistoriske, men også s forfatningsvirkeligheden «. Hvad han forstăr ved dette begreb forbliver noget uklart. For 
at vurdere forfatningsvirkeligheden burde man nok også $i$ langt højere grad, end det sker her, undersøge ikke blot, hvem magthaverne var, men også hvilken politik de førte, hvem den var til gavn for. Men det må indrømmes, at dette spørgsmåls udtømmende behandling rigeligt giver stof til endnu en bog.

Disse indvendinger bør dog ikke forklejne den store indsats, der ligger bag dette arbejde. Det vil levere værdifuldt stof til fremtidige behandlinger af byens historie og vil være vejledende og inspirerende for tilsvarende undersegelser $i$ andre byer. Men man må håbe, at forfatteren $i$ fremtidige arbejder $i$ friere og mere levende form făr lejlighed til at uddybe de uforloste perspektiver i denne bog, hvor det første, grundlæggende arbejde så kompetent er udført.

Dorrit Andersen

Ove Hornby: Striden om Filialen. Banksagen I hertugdømmerne Slesvig og Holsten ca. 1840-46.

Flensborg 1975. 128 sider, ill.

Hans Erlk Hansen: Union Bank 1875-1975,

Flensborg 1975. 120 sider, ill.

D. 9. oktober 1975 markerede Union bank i Flensborg sit 100 års jubilæum med blandt andet at udsende to bøger, "Striden om Filialen « og »Union Bank. 1875-1975 «.

Med disse to bøger følger jubilaren en god skik, der er ved at brede sig, når banker og større erhvervsvirksomheder fejrer runde tal. Man har forladt den lidt stive form for festskrifter, der bestod af lutter tabeller, statistikker og et billedstof, der mest viste stifterne med høje flipper, en form der ingenlunde gjorde festskrifterne efterspurgte.

$\mathrm{Nu}$ sætter man tit byen, egnen eller huset i focus, kæder det sammen med politiske og sociale begivenheder, så det bliver til en brik $\mathrm{i}$ historien enten lokalt eller på landsplan. Det er en vending, man kun kan hilste med al mulig tilfredshed.

De to foreliggende bøger griber ind $\mathrm{i}$ hinanden og supplerer hinanden på fortrinlig vis. "Striden om Filialen «, der er skrevet af faghistorikeren Ove Hornby, der har okonomiske forhold som speciale, bringer meget nyt og for de fleste læsere sikkert ganske ukendt stof frem.

Bogen giver ikke alene baggrunden for filialen, men kaster tillige lys over de mange stridigheder og vanskeligheder, der skulle overvindes for, at filialen kunne blive åbnet i Flensborg.

Enevoldskongers ord var lov og befaling, og 11 . juli 1840 bestemmer Chr. VIII, at banken skal åbnes, men sà ser vi, at sådan kongelig 
befaling kan forhales $i$ det uendelige. Vi når frem til 1. maj 1844, inden filialen kan slå sine porte op.

Filialbankens fødsel var vanskelig, de nationale bølger gik højt på den tid, og vanskelighederne skabtes både $i$ hertugdømmerne, hvor en stor del af modstanden var nationalpolitisk bestemt, og i København, hvor det vel nok var det mere gustne overlæg hos Nationalbankens ledelse, der var en hemsko.

$\mathrm{Da}$ banken endelig kom $\mathrm{i}$ gang, viste de første år en støt stigende omsætning, men med krigen $1848-50$ kom der nye vanskeligheder. I København frygtede man for Filialens midler, så når den slesvigholstenske eller preussiske hær nærmede sig Flensborg, flyttede man kassebeholdningen til mere betrygget område. Det er naturligt, at det under sådanne forhold giver en noget indstrænket bankvirksomhed. Ove Hornby nævner, at kasserer Torm et stykke tid var i husarrest. Det kan tilføjes, at havde det stået til den meget ivrige slesvig-holstener, Flensborgs politimester Krohn var banken blevet lukket. Han var stolt, når han kunne finde danskere, der var født $\mathrm{i}$ kongeriget, så han kunne udvise dem, og han fremsatte forslag om at udvise hele filialbankens personale, hvilket dog blev afvist fra den slesvig-holstenske regerings side, da man havde brug for banken.

Var filialbanken længe om at fremstå, fra det øjeblik »Kongen bød «, til dørene åbnedes i Storegade 2, så står som modsætning hertil afviklingen. Afviklingen skete som starten i en stormfuld tid, nu var det nazismen, der rådede. Det var en lykke, at daværende nationalbankdirektør Bramsnæs havde fremsyn og beslutsomhed, så der i tiden fra november 1938 til foråret fandtes den løsning, som i høj grad kom Union Bank til gavn, og hermed den betydning, der lå $i$, at den danske befolkningsgruppe stadig havde et dansk pengeinstitut, den betragtede som dens eget.

Lektor Hornby konkluderer, at der må en videregående forskning til, før man med sikkerhed kan belyse hele handlingsforløbet og motiverne bag det. Man må håbe, at dette resulterer $i$ en afhandling, der vil blotlægge denne detaille $i$ landsdelens økonomiske historie.

Bogen Union Bank 1875-1975 er skrevet af direktør Hans Erik Hansen, og med sans for det væsentlige forer han os gennem de forløbne 100 år fra sparekassens beskedne start til det moderne bankhus i Storegade. I årene efter 1864 er der én mand, Gustav Johannsen, der fremfor nogen er med $i$ alt, hvad der kan fremme dansk interesse. Det er derfor en selvfølge, at vi også finder ham blandt stifterne af sparekassen. Sammen med A. Randbøl, Jaruplundgård, udkaster han tanken på et møde $\mathrm{i}$ landboforeningen. Handling følger ideen op, og på mindre end et år efter det første møde er sparekassen d. 9. oktober 1875 en kendsgerning med en garantikapital på $10.000 \mathrm{mk}$., som 50 mænd hæfter for. 
Den store travlhed hersker der ikke $\mathrm{i}$ begyndelsen, man kan klare sig med at have åbent en dag om ugen, lørdag formiddag fra 10-12. Det er sikkert med velberåd hu, at det er lordag, den dag, hvor kunderne, der for en stor del er landmænd fra oplandet, alligevel er i byen. I øvrigt er kundekredsen ikke indskrænket til det nære opland, men er at finde i Nordslesvig og i kongeriget.

Op til 1. verdenskrig er væksten i sparekassen støt stigende for så at $f_{a}^{b}$ en himmelflugt $i$ inflationstiden $i$ tyverne. Men mens sparekassen dog klarer sig, så kniber det for den danske bank »Flensburger Volksbank «. Den kommer i betalingsvanskeligheder. Tilsynsrådet $\mathrm{i}$ sparekassen foreslår ved generalforsamlingen $\mathrm{i} 1926$, at man skal omdanne sparekassen til et aktieselskab og deltage $\mathrm{i}$ oprettelsen af den nye bank. Det vedtages enstemmigt, men man sikrer sig, at den nye bank $i$ de første år skal have 3 mand fra sparekassen siddende i tilsynsrådet.

Initiativet var kommet fra Flensburger Volksbanks danske kunder, der indså, at uden en dansk bank ville det ikke være muligt at opretholde danskhedens økonomiske og nationale forsvar.

Der skulle nu skaffes en aktiekapital på $250.000 \mathrm{Mk}$. Det var umuligt i Flensborg, men takket være hjxlp fra danske sparekasser og banker lykkedes det, og den nye bank var en kendsgerning d. 28. august 1926, og det bar atter opad.

Men nye vanskeligheder var ikke langt borte. 7 år senere var Hitler ved magten. Tilværelsen bliver ikke let for den, der ikke løber med. Filialbanken kunne og ville ikke acceptere de nazistiske $\mathrm{krav}$, men følte sig tvunget til at lukke efter 95 års virke $\mathrm{i}$ Flensborg, men man svigtede ikke de danske interesser. Union Bank fik tilbudt ejendommen Storegade 2 og mere kapital på gunstige betingelser, en opmuntring og håndsrækning på grænsen til 2. verdenskrig.

At føre en bank gennem krig, nederlag og pengereform må have været en voldsom belastning for bankens ledelse, men man klarede også dette, og efter pengereformen sluttede danske banker atter op om at hjælpe Union Bank, så man fik arbejdskapital. Fra 1951 har kurven været opadgående med større indskud, større balance og større udbytte.

Et utraditionelt indslag $\mathrm{i}$ bogen er skrevet af »direktøren for portokassen ", Helmuth Leckband. Veloplagt og med megen lune beretter han om sine oplevelser som bankelev i de gamle lokaler på Søndertorv. Han tegner et fortrinligt billede af miljøet, fortæller om hyggen på den lille arbejdsplads, men også om respekten for den overordnede. Tillige giver det et billede af en enklave med menneskelige forhold, i en tid hvor disse ikke stod i høj kurs.

Som indholdet har glædet tanken, glæder bøgernes udstyr øjet. De fremtræder $i$ en smuk opsætning, med godt fotografisk billedstof og Poul Leckbands smukke og meget dekorative tegninger, der pryder 
smudsomslaget og illustrerer Striden om Filialen « med såvel ex- som interiør fra den omstridte bank, der nu huser jubilaren.

Det har været 100 bevægede år, vi har gennemvandret. Vanskelighedernes mangefold har ofte været uoverskuelige, men bestandig har der været en stædig vilje til at overleve og føre det danske pengeinstitut frelst gennem de skiftende tider.

Navnene på de mænd, der stod midt $\mathrm{i}$ kampen er tillige navne på de mænd, der i medgang og modgang lagde deres $\mathrm{kræfter}$ og indsats $\mathrm{i}$ arbejdet for danskheden.

Alt $\mathrm{i}$ alt en fornem hilsen fra den 100 årige.

Poul Andersen Handwerkskammer Flensburg 1900 bls 1975. Ein Beitrag zur Geschichte des
Handwerks In Schleswig-Holstein.

Schriften der Gesellschaft für Flensburger Stadtgeschichte E. V. Nr. 25. 312 sider. Flensborg 1975.

Handwerkskammer Flensburg har sammen med Gesellschaft für Flensburger Stadtgeschichte $\mathrm{i}$ anledning af Handwerkskammerets 75 års jubilæum den 1. 4. 1975 udgivet dette interessante og fyldige skrift, der giver et godt billede af håndværkets stilling op gennem historien og specielt de sidste 75 år.

Bogen falder i 6 dele, tilrettelagt som en vandring gennem tiden. I første del gør dr. Gerhard Kraack rede for etablering af de første laug $\mathrm{i}$ middelalderen - for den historiske interesserede en god indforing $\mathrm{i}$ håndværkets historie -, hvorledes håndværket ved siden af købmændene dannede det bærende borgerskab $\mathrm{i}$ datidens bysamfund.

Man får et klart billede af, hvorledes samfundet var opbygget, og hvorledes håndværk på et tidligt tidspunkt var opsplittet og organiseret $i$ en række laugs- og håndværksfag, hvoraf størsteparten har holdt sig som fag til vore dage. Årstallene for de enkelte laugs oprettelse viser, hvorledes udviklingen breder sig fra syd til nord.

Forholdet mellem mester, svende og larlinge blev der givet særlige regler for. I forhold til $i$ dag bemærker man, at en lærling ved et læreforholds start måtte betale til en fest $i$ form af naturalier, herunder tre tonder øl. Efter udlæring var lærlingen $\mathrm{i}$ visse fag forpligtet til at fortsætte hos mesteren endnu et år for en mindre løn. Mester fik herigennem et vist vederlag for det besvær, der var forbundet med en oplæring. En særlig interesse knytter sig til en ny mesters optagelse i lauget, edsaflxggelse samt en fest for laugets medlemmer.

Dr. G. Thies omtaler handværkets udvikling $\mathrm{i}$ àrene efter den franske revolution, hvor så meget blev ændret for håndværket ved indførelse af erhvervsfrihed, hvortil kommer den begyndende industrialisering. Enhver kunne nu nedsætte sig som håndværker mod at 
lose et næringsbrev, der blev udstedt til enhver uberygtet person, der måtte ønske at etablere sig. Det omtales, hvorledes friheden havde sine grænser, hvorledes industrien påfører håndværkerne konkurrence, hvorledes enkelte håndværksmestre udvikler virksombeden til et industriforetagende, og hvorledes disse forhold for andre håndværkere betød forarmelse og overgang til industriansættelse.

Der gives herefter en fyldig redegørelse for forholdene $i$ hertugdømmet Slesvig, og hvorledes man her forsøgte at nyorganisere håndværksvæsenet. Disse bestræbelser bliver vanskeliggjort af den statspolitiske urolige tid 1844-1866. Håndværksproblemet var nært knyttet til skattesystemet, hvor byerne var pålagt større skatter end landdistrikterne, hvilket gav en fordel til landhåndværkerne. Det særlige problem for Slesvig-Holsten fandt en lesning i 1867.

Indførelse af næringsfriheden betød imidlertid en forringelse for håndværksstanden, og bl. a. blev lærlingeuddannelsen forringet. Fra håndværkets side dannede man foreninger, og statsmagten så $\mathrm{i}$ disse foreninger et middel til at forbedre håndværkets situation. Der omtales de tilløb, der blev gjort til oprettelse af fælles håndværkerforeninger, bestræbelser, der efterhånden tog fastere form, og den 4 . april 1900 kunne »Handwerkskammer zu Flensburg « træde sammen til den konstituerende forsamling.

Dr. Hans-Friedrich Schütt giver herefter en fyldig gennemgang af Handwerkskammerets første ăr, hvorledes organisationen blev regional, og hvorledes man ved afholdelse af håndvarksdage, svendeprøver, mesterprøver o. lign. søgte at højne håndværksfagene. I denne sammenhæng må også ses bestræbelserne for at etablere ordnede forhold mellem mester og svende, samt Handwerkskammerets deltagelse i forsikringsaftaler, syge- og livsforsikringer.

En sxrlig omtale får forholdene under 1. verdenskrig. Hertil kommer den xndring, der indtrådte for Flensborgs Handwerkskammer, efter afstemningen i 1920, hvor Nordslesvig stemte sig til Danmark. Allerede for afstemningen var Handwerkskammeret af de nordslesvigske medlemmer blevet orienteret om, at man efter tilbagevenden til Danmark ville udtræde af Kammeret og søge kontakt til de danske organisationer. Der bliver redegjort for de forhandlinger, bl. a. vævemester Thomas Kaufmann har med "Fællesrepræsentationen for industri og håndværk « $\mathrm{i}$ København. Overgang fra Flensburg Handwerkskammer til danske organisationsformer skete herefter uden større besværligheder, idet håndværkerne $i$ enkelte byer $f$. eks. Tønder, Løgumkloster og Højer havde betænkeligheder. Det var dog kun i Åbenrå, der fortsat forblev to tyske håndværkerforeninger.

Genforeningen betød, at 3000 selvstændige håndværksmestre trådte ud af Handwerkskammer Flensburg. Hertil kom, at det nordslesvigske marked forsvandt fra Flensborgs handel og håndværk. Handwerkskammeret havde således $\mathrm{i}$ årene efter 1920 tre store opgaver at 
klare. Først at overvinde folgerne af krigen, dernæste tabet af håndværkerne i Nordslesvig og endelig virkningen af det omsxtningsfald, der fulgte med, at Nordslesvig ikke længere på samme måde hørte med til Flensborgs håndværkeres opland.

Der var således ikke mangel på opgaver for Kammeret. Af håndværkets erhvervsmæssige forhold, herunder følgerne af grænsen giver dr. Dieter Pust et udmærket billede. Der omtales her ikke alene Kammerets virke, herunder 25 års jubilæet, men nok så meget håndværkspolitiske forhold, d. v. s. håndværket set i sammenhæng med det øvrige samfund, herunder håndværkets forpligtelse til at tage del $i$ det politiske arbejde.

Den store verdenskrise, der i Tyskland førte til Hitlers overtagelse af magten, betød store forandringer for håndværket, hvilket $\mathrm{dr}$. Hartmut Kirchhoff giver en grundig gennemgang af: hvorledes de dårlige tider for håndværkere, såvel som følge af krisen, men også som følge af håndværkets svage stilling over for den rationelle moderne industri, betød, at man fandt sammen i hjælpeorganisationer. NSDAP's magtovertagelse betod indfrielse af nogle af håndværkernes fordringer, hertil kom, at der blev sat arbejde igang; håndværket fik beskæf tigelse. Det understreges, at ved bedømmelse af håndværkets reaktion $\mathrm{i}$ disse år må ikke glemmes håndværkets fortvivlede situation, den vanskeligste $i$ nyere tid. I dette afsnit omtales også det forhold, at håndværkere $\mathrm{i}$ Nordslesvig tilhørende det tyske mindretal i et antal af 1300 i 1933 etablerede et rådgivningsorgan i Nordslesvig, ligesom Handwerkskammeret var behjxlpelig med at skaffe lærepladser, samt at der i 1933 blev holdt en tysk håndværkerudstilling i Sønderborg.

Endelig omtales, hvorledes bygmester Frahm, medlem af Kammeret i 1941, organiserede de nordslesvigske håndværk efter tysk mønster. Som slutbemærkning på denne omtale nævnes, at i øvrigt var håndværket i Nordslesvig fuldt inddraget i krigsproduktionen. Det må uden tvivl være en bemærkning, der skal læses med en vis modifikation, al den stund, at kun enkelte håndværk vel overhovedet med rimelighed kunne omstilles til krigsproduktion.

Sidste afsnit, tiden efter 2 . verdenskrig, der de første år er præget af nederlaget og især af de problemer, som den store flygtningeaktion betød for Handwerkskammer Flensburg, har dr. Schriewer givet en fyldig behandling. Krigens direkte følge blev et fald i antal håndværksvirksomheder fra 13.188 før krigen til 10.800 ved krigens slutning. Manglende råvarer, og ikke mindst den dårlige forsyning med levnedsmidler betød en stærk svækkelse af håndværket de første år. Efter valutareformen i 1948 gik det fremad, men småt. Fra midten af 1950'erne begyndte en 20-årig fremgangsperiode. Disse år gav basis for en udbygning af håndværksuddannelsen. Men også i disse år måtte det erkendes, at Handwerkskammer Flensburg er et rand- 
område, hvilket der på en udmærket måde bliver gjort rede for. Endelig omtales ændringen $i$ håndværksstrukturen - med en tilbagegang for en række traditionelle håndværksfag, medens en række nye er kommet til.

Handwerkskammer Flensburg har $\mathrm{i}$ de seneste år også haft tid til at pleje kontakter med danske håndværksorganisationer, såvel på landsplan som med kollegaer i Nordslesvig; det begyndte med et besøg i 1961 på Håndværksskolen i Sønderborg. Et samarbejde over grænsen, der har været med til at forbedre forståelsen for hinandens problemer.

Handwerkskammer Flensburg 1900-1975 er et meget værdifuldt og læseværdigt skrift, der for den, der onsker at orientere sig om hăndværket, dets tidligere og nuværende situation, giver et bredtd $æ k$ kende billede. Hertil kommer at skriftets notehenvisninger giver mulighed for yderligere at fordybe sig $\mathrm{i}$ enkeltheder, ved evt. videre studier.

Skriftet indgår således på værdig vis blandt de lokalhistoriske skrifter, man vil vende tilbage til, nằ spørgsmål om håndværket, og specielt håndværket i hertugdømmet Slesvig skal belyses.

P. Groth Bruun

Jens Christian Forman: Den internationale Kommlssions neutraliseringsforanstaltninger ved folkeafstemningen I Sønderjylland 1920.

U. år, u. st. [Århus 1976] 171 s., stencileret.

En omfattende litteratur med meget forskelligt udgangspunkt har siden 1920 beskxftiget sig med de to folkeafstemninger 10. februar og 14. marts 1920, der afgjorde den nuvarende deling af Slesvig efter principper, fastlagt i Versaillesfreden. Denne bog, der i sin oprindelige form var en specialeopgave $\mathrm{i}$ historie ved Aarhus Universitet i 1971, har Den internationale Kommission (CIS) som hovedemne, nærmere betegnet det centrale spørgsmål, om CIS' administration $\mathfrak{i}$ afstemningszonerne formåede at løse den svære opgave at give begge parter fair play, således at afstemningsresultatet blev repræsentativt for folkeviljen. Både fra tysk og til dels fra dansk side har ikke alene fredstraktatens bestemmelser, men også CIS' administration været udsat for skarp kritik. Det er især sket i forbindelse med afstemningen i 2. zone, for i zone 1 var afstemningsresultatet givet på forhånd, og det gav en mindre forbitret afstemningskamp, således som det også fremgår af Formans fremstilling.

Forman analyserer spørgsmålet på en meget bred baggrund og inddrager hele CIS' funktionsperiode fra 8. aug. 1919 til 16. juni 1920. Analysen er baseret på et omfattende trykt og utrykt kildemateriale, bl. a. den del af CIS' arkiv, der findes på mikrofilm i Rigsarkivet, kommissionspræsidentens indberetninger til den engelske 
udenrigsminister, diverse materiale fra det tyske udenrigsministerium og endelig afstemningsarkivet i Stadtarchiv Flensburg. Til gengæld er der ikke gjort noget forsøg på at inddrage materiale fra private personarkiver i Rigsarkivet og landsarkivet i Åbenrå. Muligvis ville sådanne undersøgelser heller ikke have givet resultater, der stod $\mathrm{i}$ et rimeligt forhold til den formentlig meget besværlige og tidskrævende arbejdsindsats; men de kunne måske alligevel have uddybet billedet af de danske reaktioner på CIS' virksomhed. Det afgørende må imidlertid være, at Formans bog er blevet et meget væsentligt arbejde, ikke blot om CIS i snævreste forstand, men om afstemningstiden $i$ det hele taget, præget som den er af forfatterens omfattende viden, sikre, kritiske dømmekraft og klare fremstilling. Således er den f. eks. blevet et væsentligt korrektiv til en af de nyeste tyske bøger om emnet, Hans Dietrich Lehmann: Der "Deutsche Ausschuss" und die Abstimmungen in Schleswig 1920 (1969) og dermed ogsa til senere tyske arbejder, der bygger på denne bog. I eksempel efter eksempel dokumenteres overbevisende de store metodiske svagheder og partiskheden i Lehmanns fremstilling. Men Forman er ogsa kritisk over for danske angreb på CIS, således som de f. eks. skarpt er formuleret i Ernst Christiansens bidrag til Slesvig delt (1922). Han konkluderer, at CIS' forholdsregler stort set var rimelige ud fra de givne forudsætninger, og inddrager til slut til sammenligning de tilsvarende østlige afstemningskommissioners arbejde, der fik et mindre heldigt forløb end den slesvigskes.

Forman mener, at det $\mathrm{i}$ vore dage også er den udbredte opfattelse i danske og tyske kredse, at CIS' neutraliseringsarbejde og virksomhed $\mathrm{i}$ øvrigt før og efter afstemningerne var ganske vellykket. Dette kan dog næppe gælde de snævrere historikerkredse, sådan som Lehmanns bog netop viser, og på dansk side er spørgsmålet måske heller ikke helt uddebatteret. Derfor bør Formans, i denne sammenhrng måske lidt kontroversielle, bog vække stor interesse både på dansk og tysk side, og den vil være væsentlig for alle, der interesserer sig for grænsedragningen i 1920 og de faktorer, der bestemte afstemningsresultatet $i$ zone 2 . Derfor må man beklage, at bogen kun er kommet i et begrænset, duplikeret oplag, der tilmed ikke kan købes på normal vis. Det er ikke umiddelbart forståeligt, at udgiverne, det tidligere århusianske grænseforskningsprojekt, med henvisning til bogens "meget minutiøse analyse", har valgt en så selvudslettende publikationsform, der er helt uretfærdig over for det væsentligste danske arbejde om afstemningerne $i$ en årrække. Såfremt det meget begrænsede restoplag tillader det, stiller projektet dog eksemplarer til rådighed for særligt interesserede ved henvendelse til lektor J. P. Noack, Institut for Historie, Aarhus Universitet, 8000 Århus C. Det må stærkt anbefales at forsøge denne mulighed.

Dorrit Andersen 
Johan Peter Noack: Det tyske mindretal I Nordslesvig under besættelsen.

Dansk udenrigspolitisk Instituts skrifter nr. 6, København 1975. 213 s.

Universitetslektor Johan Peter Noacks bog om det tyske mindretal i Nordslesvig under besættelsen placerer sig naturligt blandt de seneste års historiske og samfundsvidenskabelige forskning omkring sønderjyske og grænsepolitiske emner efter 1920. Der tænkes her først og fremmest på Sven Tägils bog om Tyskland og det tyske mindretal 1933-39 og Bjarne W. Frederiksens analyse af den danske sydslesvigpolitik efter det tyske sammenbrud i 1945. Nu er Noacks bog udkommet i "Dansk udenrigspolitisk Instituts skrifter «, hvilket placerer det tyske mindretals politiske bestrxbelser i en udenrigspolitisk sammenhæng, omend der dog her bliver tale om udenrigspolitik i besættelsestidens særprægede form.

Som titlen antyder har Noack sat det tyske mindretal $\mathrm{i}$ centrum. Noack har disponeret afhandlingen tematisk efter mindretallets prioritering af politiske mål. Efter en indledning, hvor problemstillinger fremføres, og kildematerialet, udviklingen i mellemkrigstiden og de tyske grænsepolitiske instanser præsenteres kortfattet, er bogens hovedafsnit en analyse af mindretallets væsentligste politiske mål, en revision af grænsen af 1920 . Dernæst følger et sidemæssigt lidt kortere kapitel om hvervningerne til Waffen SS og problemerne omkring de paramilitære korpsdannelser udgået fra mindretallet. Herefter behandles mindretallets sekundxre politiske mål: den nazistiske ensretning og den organisatoriske opbygning, Kreditanstalt Vogelgesang og de tyske banker, autonomiplaner, oprettelsen af det tyske kontor under Statsministeriet, forhandlinger om skole- og kirkeautonomi. Et selvstændigt kapitel vies de sidste krigsår, hvor den politiske polarisering inden for mindretallets rækker fremstilles. I en slutning samles og drøftes afhandlingens resultater, hvorpå der så følger 4 ekskurser, hvor blandt andet Hitlers udtalelser om grænsespørgsmålet og årsagerne til, at Nordslesvig ikke blev genindlemmet $\mathrm{i}$ Tyskland, undersøges.

Noack har stået over for den væsentlige hindring, at mindretallets eget arkiv ikke har været til disposition for undersøgelsen. Mindretallet destruerede selv dette arkiv i forbindelse med besxttelsens ophør. Derfor har Noack i særlig grad været henvist til at benytte arkivalierne fra det tyske udenrigsministerium, Auswärtiges Amt. En betydelig del af dette aktmateriale har allerede været publiceret i den Parlamentariske Kommissions betænkning bd. 14. Dette materiale er suppleret med yderligere, senere tilgængeliggjort, dokumentstof af tysk proveniens. En væsentlig hemsko har desuden været, at Volksdeutsche Mittelstelle's (Vomi) arkiv også er gået til grunde under krigen. Dette tyske organ varetog nemlig en række spørgsmål omkring mindretallets interne forhold. Ialt finder Noack dog dette ma- 
teriale tilstrækkeligt repræsentativt til at kunne besvare de formulerede problemstillinger, hvilket den efterfølgende fremstilling da også giver et godt indtryk af. Netop manglen pà partiinternt dokumentstof gør dog, at selv om titlen nævner det tyske mindretal som hovedaktør, koncentreres fremstillingen $i$ realiteten om selve mindretalsledelsen, der opfattes som reprasentativ for holdningerne inden for hele mindretallet.

Noack har lagt to hovedsynspunkter til grund for afhandlingen. Det første er, at det er en politisk fornuftig opfattelse, at spæendingen omkring den dansk-tyske grænse holdes på et så lavt niveau som muligt, og det andet er, at de demokratiske organisationsformer er mere efterstræbelsesværdige end totalitærtdiktatoriske«. Disse synspunkter er generelt accepterede $i$ det danske samfund og kan derfor ikke siges at være vidtgående. Dog er de sikkert ikke de eneste synspunkter, som ligger til grund for forfatterens videnskabelige forklaringer.

Ud fra disse hovedsynspunkter betragter Noack det som en central opgave at lokalisere de konfliktfremkaldende og de stabiliserende faktorer i besættelsestidens grænsekonflikt og at undersøge forløbet af mindretallets organisatoriske politiske ensretning. Dette stiller naturligvis som forudsætning, at det samtidig klarlægges, hvad der var mindretalsledelsens politiske målsætning, og hvilken taktik den fulgte for at virkeliggøre denne. Derefter rejser Noack en række afledede spørgsmål til uddybning. Han sætter sig som mål at afdxkke, hvor afhængig mindretallet $i$ politisk forstand var af den tyske besættelsesmagt, og hvorledes forholdet mellem mindretal og tyske myndigheder udviklede sig. Problemstillingerne må siges at være særdeles relevante for forstålsen af mindretallets situation under besættelsen. To ellers vesentlige emner har Noack valgt at holde udenfor. Det drejer sig om mindretallets økonomiske udnyttelse af besættelsessituationen og en nærmere undersøgelse af mindretallets sociale struktur; den sidste er udeladt som følge af mangel på egnet kildemateriale. Disse rejste problemstillinger forfølges med grundighed.

Noacks undersøgelse munder ud i den konklusion, at konfliktintensiteten var størst i juni 1940, det såkaldte junirøre, og i sommeren 1941 efter det tyske angreb på Sovjetunionen. Det kan også siges således, at det var de to tidspunkter, hvor mindretallets forventning om en ensidig tysk grænserevision kulminerede. De faktorer, som Noack mener intensiverede spændingen, var først og fremmest forskydninger $i$ de storpolitiske konjunkturer og den politiske og organisatoriske ensretning samt den totalitære ideologi. Partiledelsen gav $i$ et vist omfang efter for pression fra mindretallets menige rækker; det var reaktion fra danske og tyske myndigheder, der forhindrede, at situationen lob ud af kontrol.

Som bekendt led mindretalsledelsen nederlag på dets primære politiske mål, en grænserevision. Hitler-Tyskland lod sig ikke formå til 
at gennemtvinge noget sådant, væsentligst fordi forhandlingspolitikken i Danmark ikke ønskedes bragt i fare. Desuden mener Noack, at Tyskland desuden frygtede, at en grænserevision ville støde opinionen i USA stærkt; men der er nu langt fra Skelbækken til Potomacfloden. Noack er ikke heldig med at sætte dette hensyn ind $i$ en for læseren forståelig sammenhæng. Han konkluderer endvidere, at det danske flertal også havde betydning, og $\mathrm{i}$ forhold til disse to hensyn udgjorde planerne om Danmarks indpasning $\mathrm{i}$ et storgermansk rige, efter hans mening, kun et sekundært moment.

Her kommer den væsentligste svaghed ved Noacks bog frem. Den tyske besættelsespolitik og virkningerne af mindretallets pres sættes ikke ind $i$ en samlet tysk udenrigspolitisk ramme. Opfattelsen af den amerikanske opinions betydning støtter sig til den vurdering, som den danske historiker Henning Poulsen har fremlagt $i$ sin disputats om »Besxttelsesmagten og de danske nazister « med støtte $i$ den tyske historiker Andreas Hillgrubers værk om Hitlers strategi 1940/41. Denne vurdering har nok relevans for besættelsessituationen; men den forudsætter samtidig, at det nazistiske Tysklands ekspansive krigspolitik havde et langsigtet mål, et storgermansk rige. Noack diskuterer i ekskurs 2 (s. 187ff) årsagerne til, at Nordslesvig ikke blev genindlemmet $\mathrm{i}$ Tyskland. Her modstilles Troels Finks forklaring, som fremført i "Sønderjylland siden genforeningen i 1920 «, og Henning Poulsens forklaring. Hovedproblemet reduceres derved til, om det var "aktuelle politiske hensyn til forhandlingspolitikken og de faktorer, der har været bestemmende for dens etablering og opretholdelse" (Poulsen) eller »ideologisk betingede hensyn til regimets fjernmål, planer om et storgermansk rige" (Fink). Noack lægger klart eftertrykket på det førstnævnte synspunkt. Imidlertid er det meget vanskeligt at se, at det overhovedet er meningsfuldt at adskille på den måde, som Noack her har gjort. Spørgsmălet er, om de to forklaringer ikke hører intimt sammen. For Henning Poulsen bliver det nazistiske regimes fjernmål, det storgermanske rige, af stor betydning for besættelsesmagtens adfærd $i$ anden halvdel af 1940, bl. a. for hvervningerne til SS; men i den sammenhæng polemiserer Noack mærkværdigvis meget grundigt med Henning Poulsens opfattelse.

Noacks »ideologiske hæmninger « kommer frem ved behandlingen af hvervningerne til Waffen SS. I spørgsmålet om hvervningerne argumenterer Noack som nævnt for en anden opfattelse af årsagerne til SS-hvervningerne i Danmark end den, som Poulsen overbevisende har fremlagt. Noack skriver således s. 93: "Også her står man over for at skulle afveje behovet for mere mandskab mod et ideologisk moment «. Efter en række forbehold over for "ideologiske momenter " konkluderes: »Havde resultaterne betydet mindre end ideologien, havde man vel også været tilbøjelig til at udfolde det betydeligt større mål af omhu og takt, som en sả delikat sag krævede«. Vel, det 
er ingen hemmelighed, at SS ikke lagde den store taktfølelse for dagen ved hvervning af mandskab til Waffen SS. Imidlertid ligger nøglen til forklaringen på SS's adfærd i den ideologiske målsætning, de storgermanske tanker, der ikke levnede megen plads for mindretallets og de danske nazisters sarte nationale folelser. Netop det tilsyneladende ubehændige i SS's praksis har ladet Noack friste til at give det uhåndgribelige storgermanske rige en underordnet betydning $i$ forhold til »SS kanonføde«. Adfærden på andre områder kan naturligvis ikke uden videre overføres til denne sammenhæng, men at der tilsyneladende var hold i de mere kontroversielle nazistiske mål, turde vare bevist ved den konsekvens, hvormed man under krigens tryk løste " jødespergsmålet .

Forfatteren kommer desuden frem til, at den holdning, som partiledelsen indtog $\mathrm{i}$ grænserevisionsspørgsmålet, var dikteret af opinionen i mindretallet. Ledelsens dilemma var, at de tyske myndigheder krævede ro om grænsen, mens mindretallet krævede mellemkrigstidens revisionistiske forventninger indfriet, når tyskerne nu havde magten i Danmark. Mindretalsledelsen balancerede her og forsogte at kanalisere aktiviteten ind $\mathrm{i}$ organisatoriske baner. Efterhånden som krigsudsigterne tegnede sig mørkere for en tysk sejr, aftog dette pres, og mindretallet begyndte langsomt at distancere sig fra besættelsesmagten og nærme sig det danske samfund igen. Grunden til, at mindretalsledelsen accepterede hvervningerne, finder Noack i lydighedsforpligtelsen over for Tyskland og $i$, at ledelsen havde vovet sig så langt ud, at et tilbagetog ville betyde et stort prestigetab. Mindretallet onskede at oparbejde en good-will hos de tyske myndigheder med henblik på den dag, hvor grænsespørgsmålet blev modent til en endelig løsning. Men mindretalsledelsen så også en fare $\mathrm{i}$ hvervningerne, der på længere sigt kunne betyde en svækkelse af den nationale styrke. Efterhånden blev det også klart, at SS ikke ville støtte grænserevisionskravet. SS tænkte som tidligere nævnt ikke i traditionelle grænsepolitiske baner. Større forståelse for mindretallets synspunkt fandtes i Auswärtiges Amt. Mindretalsledelsen loste delvis problemet omkring hvervningerne ved at erklære et øget antal for wunabkömmlich «. Retningslinjerne til brug ved udvælgelsen af de uundværlige skulle sikre, at folkegruppens okonomiske og politiske positioner ikke kom i fare. Det førte til kritik af ledelsen for social diskriminering ved udvælgelsen. Her er vel egentligt et strålende eksempel på, hvilken indflydelse mindretallets politiske principper fik i praksis. I modsæetning til Sven Tägil og til dels også Troels Fink kommer Noack til den vurdering af mindretallets nazificering og ensretning, at den ikke kunne anses for afsluttet ved krigens begyndelse. I løbet af besættelsen lykkedes det ifølge Noack at opnå et mere enigt fodslag. Ensretningsbestræbelserne var knyttet til forsøgene på national ekspansion, som skulle øge mulighederne for en grænserevision. 
Da den tyske militære offensiv var kørt fast i slutningen af 1941, begyndte mindretallet $\mathrm{i}$ højere grad at søge de sekundxre mål virkeliggjort. Mindretalsledelsen ønskede en autonom status inden for den danske stats rammer. Det blev i 1943 til det tyske kontor under Statsministeriet og en begyndelse på forhandlinger om mere selvstæendige kirke- og skoleforhold. Efterhånden tiltog den polarisering, som Noack fremhæver som karakteristisk for besættelsestidens slutfase. Her kan man dog sige, at der kun var tale om den opinion, som kom offentligt frem. Hvorvidt denne polarisering har været lige så udtalt i de meniges rækker, gives der ingen nærmere undersøgelse af. Dog fremhæver Noack, at oppositionen, de detroniserede konservativtnationale, først kom frem til overfladen, da Tyskland for alvor var på tilbagetog. Som forklaring herpå nævnes, at denne opposition ikke på afgørende punkter var uenig med den nazistiske partiledelses målsætning.

I slutningen skriver Noack, at det ville være en naturlig konsekvens af partiledelsens politiske nederlag $\mathrm{i}$ besættelsens første år, at den trådte tilbage. Dette skulle have skabt mulighed for en ændring af mindretallets politiske målsætning, således at mindretallet ikke kom til at yde ofre på falske præmisser. Noack peger på, at dette bl. a. havde begrundelse $i$ den nazistiske ideologis veludviklede førerrolle, hvor der ikke var mulighed for at indrømme en fejlagtig politik. Her kan man spørge, hvor sigende en sådan betragtning er. Det forudsætter generelt en betydelig større politisk uafhæengighed hos partiledelsen end den, som ledelsen tilsyneladende har haft, især hvis det kunne medføre prestigetab hos besxttelsesmagten. Netop mindretallets økonomiske afhængighed har sikkert begrænset dets handlefrihed stærkt. Imidlertid er det også spørgsmålet, om man i det hele taget kan tale om "en forfejlet politik «. Hvilke alternativer havde det nazistiske mindretal i den situation, hvor Danmark var besat af den tyske værnemagt? Problemet ligger nok så meget $i$, at de tyske myndigheder slet ikke gjorde mindretallet tilstrækkeligt klart, at den revisionistiske fase af tysk udenrigspolitik for alvor var gået ind $i$ en ekspansionistisk. En traditionel grænsepolitisk problemstilling holdt udenrigstjenesten fast ved af pragmatiske årsager.

Efter en længere udredning af forholdet mellem Auswärtiges Amt og Vomi sammenfatter han sin afvejning af de to organers indflydelse således (s. 29): »Alt $i$ alt er der altså næppe grund til $i$ Volksdeutsche Mittelstelle at se en formidabel rival til Auswärtiges Amt, og da slet ikke for besættelsestidens vedkommende. Ganske vist var Vomi en del af Himmlers frygtede SS, men det synes modelleret som redskab for en udenrigspolitisk linie, Hitler allerede for besættelsen var skredet langt hen over «. Til denne konklusion kan man meget rimeligt spørge, om det ikke også gjaldt det tyske udenrigsministerium. Krigsårene medførte $i$ de indretyske magtrelationer en højkon- 
junktur for Himmler og hans omfattende SS-apparat. At udenrigsministeriet havde så fremskudt en position i Danmark, skyldtes nok så meget den ordning, forhandlingspolitikken, som etableredes den 9 . april 1940. Den vurdering, som Noack her står alene med, stemmer ikke overens med Sven Tägils og Troels Finks bedømmelse af Vomi's (SS's) indflydelse. Noacks påstand om, at Vomi kun havde perifer indflydelse, bygger på det tyske udenrigsministeriums dokumentmateriale. Men den formelle kompetancedeling mellem Vomi og Auswärtiges Amt tyder ikke herpå.

Et væsentligt argument for Auswärtiges Amt's styrkeposition er den kendsgerning, at udenrigsministeriet havde et etableret administrativt apparat og informationskanaler til rådighed, mens Vomi kun havde en mindre faststruktureret kontaktflade til mindretallet. Det er dog en kendt sag, at et administrativt apparat ikke nødvendigvis behøver at være ensbetydende med politisk indflydelse, og da slet ikke i Det tredje Rige. Ganske vist stod Auswärtiges Amt for udførelsen (og ikke som man făr indtryk af side 21 udformningen) af den tyske besættelsespolitik i Danmark, og Vomi måtte holde sig inden for de rammer, som kunne sikre forhandlingspolitikkens opretholdelse, indtil andet måtte blive besluttet på højeste plan. Her var begge tyske instanser henvist til samarbejde. Vomi havde som sagt med mindretallets interne forhold at gøre; men både umiddelbart efter den tyske okkupation informerede Vomi's representant mindretallet om, at grænsespørgsmålet ikke måtte rejses, og ved den definitive omlægning af mindretallets politik i december 1940 holdtes det afgørende møde i Vomi. Vomi blev desuden ophøjet til et SS-Hauptamt i 1941 og burde nok i højere grad have været vurderet i sammenhæn med det samlede SS-apparat, som først og fremmest koncentrerede sig om de politisk betingede hvervninger til Waffen SS.

Den tematiske, og ikke den traditionelle kronologiske fremstillingsmåde, som Noack har disponeret sin afhandling efter, er ikke helt vellykket. Ved at adskille behandlingen af grænserevisionskravet og hvervningerne til Waffen SS bliver det nodvendigt med gentagelser, og det stiller store krav til læseren for at fastholde overblikket; men væsentligst er det, at den indre sammenhæng mellem emnerne fortoner sig.

Noack har et grundigt kendskab til sit emne og det relevante kildemateriale, som også har givet bogen en plads $i$ den videnskabelige litteratur om besættelsestiden. En styrke ved Noacks bog er analysen, hvor han i forskellige sammenhænge opstiller og diskuterer alternative fortolkningsmuligheder af mindretallets taktiske overvejelser over for besættelsesmagten. Det er en videnskabelig dyd ikke at undlade at tage mulige forklaringstyper under behandling. Undertiden synes det dog at blive for omstændeligt, men det animerer læseren til debat og modsigelse, hvilket er positivt. 
Det er uheldigt, at Noack i så høj grad "afideologiserer « de tyske krigsmål, den tyske besættelsespolitik og til dels også mindretallets politik. I arbejdet med besættelsestidens historie kan man ikke komme uden om en stillingtagen til den nazistiske ideologi og dens betydning, også selv om man herved skulle komme til at nærme sig retsopgørets problematik.

Bjørn Rosengreen

\section{Anders Ture Lindstrøm: Landet Slesvig-Holstens polltiske hlstorle I hovedtræk 1945-1954.}

Flensborg 1975. Udgivet af Studieafdelingen ved Dansk Centralbibliotek for Sydslesvig. 200 sider.

For en ung dansk historiker kan det synes en vovelig sag at skrive en selvstæendig bog om et nabolands nyeste historie; men Anders Ture Lindstrøm har haft gode forudsætninger for et sådant arbejde, idet han selv voksede op syd for grxensen netop i de kaotiske år efter 1945 og siden som stipendiat ved det danske centralbibliotek i Flensborg har fået adgang til værdifuldt kildestof om emnet. Det drejer sig forst og fremmest om Hans Hedtofts Sydslesvig-papirer og Sydslesvigsk Forenings arkiv; det havde været endnu mere spændende, hvis det havde været muligt at få tilsvarende stof fra SPD's og CDU's partiarkiver. I bogens omfattende litteraturliste savner jeg enkelte ting, bl. a. Hermann Clausens erindringsbog fra 1966 om byen Slesvig efter de to verdenskrige.

Lindstrøm nøjes ikke med at skildre nationalitetskampen i Sydslesvig, men giver en samlet fremstilling af hele den politiske udvikling, både den indre og den ydre, for det Land Schleswig-Holstein, som bortset fra oprørsårene 1848-50 aldrig har eksisteret som land, før den britiske militxerregering oprettede det i 1946. Såvidt jeg kan se ud fra mit kendskab til tingene, er Lindstrøm sluppet godt fra opgaven. Han deler sol og vind lige mellem de skiftende regeringer $\mathrm{i}$ Kiel. Først den svære start under den tiltalende kommissariske ministerpræsident Steltzer. Så SPD’s meget vanskelige regeringsår 194750 med frygtelig nød, flygtningeelendighed og rekordarbejdsløshed, der toppede $\mathrm{i}$ vinteren $1949-50$, da Flensborg by havde $33 \%$ arbejdsløse foruden krigsinvalider, krigsenker og andre med offentlig understøttelse; Lindstrøm får dog ikke rigtig fortalt om regeringsskiftet fra Lüdemann til Diekmann i 1949. Derefter CDU's dominans, der nu har varet over 25 år. Den byggede i starten delvis på CDU's held med netop at komme til magten kort efter, at den tyske elendighed havde kulmineret, men skyldes også som fremhævet en dygtig og målbevidst indsats, især af den energiske og hårdhændede ministerpræsident Fr. Lübke fra 1951. Han havde i modsætning til andre 
CDU-ministerpræsidenter ikke været nazist og optrådte endda $\mathrm{i}$ begyndelsen af 1946 som udpræget danskvenlig og blev valgt til stedfortrædende landråd i Flensborg amt med dansk støtte, men afslørede sig senere som danskhedens fjende nr. 1.

At Slesvig-Holsten overhovedet blev til et sxrligt »land «, skyldes briternes ønske om at bygge et nyt demokrati op på et stærkt lokalt selvstyre $\mathrm{i}$ bevidst modsætning til det tidligere prøjsiske centralstyre, en helt rigtig tanke, som også prægede den nye (vest)-tyske grundlov af 1949. Også det britiske onske om at feje den nazistiske ledelse væk i kommuner, kredse og lande var helt $\mathrm{i}$ orden, men lykkedes kun delvis. Briterne gabte over alt for meget ved at prove at nafnazificere * alt og alle ved en *Fragebogen * med over 100 spørgsmål (i 6 eksemplarer - i en papirfattig tid!) foruden den helt store for dem, der skulle godkendes som embedsmænd. Inden længe var militærregeringens folk ved at kvæles $\mathrm{i}$ disse papirbunker, som også var umulige at kontrollere; bl. a. registreredes der mærkværdigt få tidligere nazister blandt de mange østtyske flygtninge. Det hele udviklede sig til en farce, og efter CDU's magtovertagelse i 1950 sad ganske store nazister snart igen på ledende poster både som politikere og embedsmænd. Det er karakteristisk, at Flensborgs nazi-overborgmester fra 1936-45 Kracht blev "leitender Landesdirektor " i Kiel (svarer til departementschef i Statsministeriet i København), mens antinazisten Pagel blev afvist som ministerpresident, fordi han havde familieforbindelser i England. Man har undskyldt sig med, at det kun var de energiske gamle naziembedsmænd, som kunne få gang i Tyskland igen - især, da USA ville remilitarisere det afvæbnede Tyskland som værn mod Sovjet -; men det var en dårlig undskyldning. I 1945 havde de jæune tyskere fået nok af nazisterne, og der fandtes tilstrækkeligt mange gode folk, som kunne bruges på ledende poster. Det bevistes bl. a. i Flensborg, hvor det danskledede bystyre, som fik denne store by på fode igen ved en ærlig indsats i de uhyre svære år til 1951, ikke omfattede en eneste, som havde været medlem af nazipartiet.

Forfatteren skildrer ret udførligt CDU's udvikling og endnu nøjere SPD's. Derimod nævner han knap nok kommunist-partiet i SlesvigHolsten, måske fordi det var så lille, at det let kan overses. Men det er just det bemærkelsesværdige. I 1932 fik KPD 13-14\% af stemmerne i Sydslesvig og Holsten, og man kunne have troet, at partiet ville stå endnu stærkere, efter at Hitlers »tusindårsrige" var brudt sammen. Det gik modsat. Ved valget i 1947 fik KPD mindre end $5 \%$ af stemmerne, sikkert nok fordi mange tyskere nu havde personligt kendskab til Sovjet-forhold, bl. a. flygtningene fra Østtyskland, og absolut ikke ønskede nogen russisk besættelse. Sxrlig lav var den kommunistiske procent i Sydslesvig, hvor især arbejderne fylkede sig under de danske faner og derved holdtes samlet pà en sikker de- 
mokratisk linie; i Flensborg var der ikke engang $2 \%$ kommuniststemmer. - På den baggrund forekommer det senere forbud mod kommunistpartiet i Tyskland hysterisk og dumt ligesom den nye lov mod "ekstreme* bevægelser, hvis praktisering mod venstre-orienterede virker særlig grel på baggrund af de foregående tiårs manglende opgør med forhenværende stornazister.

Bogen skildrer meget godt det enorme flygtningepres. SlesvigHolstens flygtningeprocent var langt højere end de andre vesttyske landes, og i det mindre krigshærgede Sydslesvig var den endnu højere end i Holsten. Rekorden havde Rantum kommune på Sild med 10 flygtninge for hver fastboende. Det var baggrunden for, at flygtningene netop $i$ dette land fik en så stærk stilling med deres eget parti $i$ landdagen, BHE, at de kunne tiltvinge sig store, langvarige særfordele, som betød en yderligere forringelse for de hjemmehørende, hvis unge nu selv $i$ stort tal måtte rejse bort fra deres hjemstavn. Flygtningene blev $\mathrm{i}$ det hele taget ikke vel modtaget $\mathrm{i}$ Vesttyskland; Bøgh Andersen sagde med rette: »Man kan nu se, at tyskerne ikke er et folk, men kun et sprogfxllesskab «. Men i Sydslesvig kunne flygtningene bruges mod danskerne. Der skulle bygges men vold af flygtningebønder langs grænsen «, og som nævnt i bogen erklærede Lübke i 1953, at de nye landbrug under "Program Nord" kun ville blive givet til tyskere.

Lindstrøm placerer den strerke danske rejsning i Sydslesvig som en af Kielpolitikernes helt store hovedpiner ved siden af efterkrigstidens mange problemer. Jeg kan her referere 3 vigtige udtalelser fra ledende tyskere. En af vore skarpeste modstandere i Kiel, finansminister Schenck, sagde engang $i$ de hårde kampår noget meget klogt og rigtigt $i$ en tysk forsamling; det kan kort gengives sådan: "Det er forkert og dumt at kalde de dansksindede sydslesvigere forredere eller Speckdänen. De er ikke tyskere på samme måde som holstenerne eller andre stammer sydpå, men blev efter 1864 indlemmet i Prøjsen, hvad flertallet af dem affandt sig med ("Staatsangewöhnung «). Nu i 1945 oplestes dette statsbånd for første gang siden 1866, og i den situation går slesvigerne den vej, deres instinkt fører dem, og det er for $75 \%$ af dem nordpå. - Lübke takkede nogen tid før sin død i 1954 offentligt flygtningene og briterne, fordi de havde reddet Sydslesvig for Tyskland. Han nævnte ikke den vigtigste årsag, nemlig Kobenhavn. Den fremhærvedes derimod $\mathrm{i}$ »Flensburger Tageblatt «s overskrifter, f. eks. "Dänemark will nicht«. - Redaktør Hanno Schmidt, hvis bror $i$ ovrigt gik $i$ dansk skoletjeneste, sagde engang efter $1955 \mathrm{i}$ et fortroligt øjeblik til den danske byrådsfraktions formand Fr. Mommsen, at han ikke fattede, hvordan det gik til, at Flensborg ikke blev dansk efter 1945. "I kunne have klædt byen i redt og hvidt fra nord til syd og fra øst til vest. Der var ingen tysk modstand.* 
Bogen giver en særligt værdifuld beretning om SPF, Flensborg bys socialdemokratiske parti, som efter 1945 nægtede at gentage partiets parole fra 1920: "Stem tysk « og holdt fast ved at lade sine medlemmer vælge frit mellem dansk og tysk. Derfor blev SPF i juni 1946 ekskluderet af det vesttyske SPD's formand Kurt Schumacher, som blev forledt dertil af de skrapt nationale SPD-folk i Kiel. Dette drastiske skridt medførte, at næsten alle de flensborgske arbejdere lige til 1954 stod samlet $\mathrm{i}$ den danske bevægelse med det klare ønske at få byen genforenet med Danmark. Men på grund af den britiske grænsespærring var det $\mathrm{i}$ de første år svært for SPF at få personlig forbindelse med det danske socialdemokrati. Til Lindstrøms oplysninger herom kan jeg føje, at den senere kirkeminister Frede Nielsens første besøg syd for græensen fandt sted i marts 1946, at Reiser og Münchow $\mathrm{i}$ december samme år for første gang var $\mathrm{i}$ Kobenhavn til møde med Hedtoft m. fl., og at Hedtoft den 12/6 1947 for første gang besøgte Flensborg.

Hedtoft og andre ledende danske socialdemokrater var i private samtaler nogle gange inde på tanken om en grænse syd om Flensborg, men partiet som sådant fastholdt parolen fra maj 1945 "Grænsen ligger fast«, skønt det for mange af dets medlemmer ligesom for mange radikale var svært at fornægte selvbestemmelsesretten i praksis. Baggrunden herfor var, at den indrepolitiske situation i Danmark var låst fast $\mathrm{i}$ den golde strid for og imod Knud Kristensen lige til slutningen af 1947, og snart derefter gjorde den storpolitiske udvikling det umuligt at få Storbritannien med til et sådant indgreb mod Tyskland. Det sidste er nok baggrunden for Hedtofts holdning under en vigtig episode i 1951 - altsă et par år efter, at "toget var kørt " fra sydslesvigerne, storpolitisk set; den nævnes ikke $\mathrm{i}$ bogen og er altså nxppe refereret $\mathrm{i}$ Hedtofts papirer, men er omtalt af den danske SPF'er W. L. Christiansen i Flensborg Avis 22/1 1976. Mit notat herom er fra 1/6 1951, altså noget tidligere end hans, men stemmer i øvrigt godt med det, idet vi bygger på samme kilde, den socialdemokratiske tillidsmand Svend Sørensen fra København. Han fortalte, at Schumacher under Hedtofts Tysklands-besøg midt i februar 1951 havde tilbudt SPD's støtte til alt, hvad Hedtoft onskede i grænsespørgsmålet: $\gg \mathrm{Du}$ kannst alles haben, das Selbststimmungsrecht, einen Paragraphen 5 oder sonst was", men at Hedtoft havde sagt nej. Schumacher var da forøvrigt også kun oppositionsfører i Bonn ligesom Hedtoft $\mathrm{i}$ Kebenhavn.

Det afgørende for grænsespørgsmålet var altså Københavns nej og for SPF's skæbne afvisningen fra det danske socialdemokrati, som også fremhævet af Lindstrøm. Efter et made den $28 / 31953$ med SPF's ledelse noterede jeg, at en fra Reiser-fløjen havde sagt, at hendes stilling var afgjort af partifællerne nordpå, som sagde: $* V_{i}$ vil slet ikke have jer. Sørg for at komme tilbage til SPD «. Den hårde 
og uforstående afvisning fra København var en bitter skuffelse for det store flertal af flensborgerne, som efter Hitlertidens oplevelser inderligt ønskede at følge Nordslesvigs eksempel fra 1920.

\section{Frants Thygesen}

\section{Andreas Gayk und selne Zelt 1893-1954. Erinnerungen an den Kleler Ober-} bürgermelster.

Udg. af Jürgen Jensen og Karl Rickers. Karl Wachholtz Verlag. Neumünster 1974. 267 sider, ill.

Den politiske økonomiske og sociale udvikling i Slesvig-Holsten 1918-33, 1933-45 og i tiden efter 1945, da Slesvig-Holsten og det ovrige tyske område af de allierede blev befriet for nazismen og fik en chance for at vende tilbage til civilisationen, er endnu langtfra tilstrækkeligt belyst. Stoffet er spændende nok, men trænger til mere udfordring. Det gælder for slesvig-holstensk regionalhistorie 193345 , som man i Slesvig-Holsten tilsyneladende slet ikke onsker at beskæf tige sig med; det gælder også for udforskningen af tiden efter 1945.

Personalhistorisk gxlder det, at der findes et betydeligt antal politikere, embedsmænd, erhvervsmænd og andre notabiliteter, som man gerne vil se bearbejdet seriøst, så man kan se deres udvikling gennem tyverne, trediverne, fyrrerne og for nogles vedkommende halvtredserne.

Det vil f. eks. være af stor interesse at se mere udførlige skildringer af slesvig-holstensk landbrugs ledende skikkelser i dette århundrede. Mænd som Jensen-Oksager og Fr. W. Lübke har måske nok fået den politiske respekt, som deres indsats i tysk tjeneste måtte berettige til. Men den nøgterne og nuancerede historiske vurdering, som de har krav på, har man ikke set meget til.

Heller ikke den slesvig-holstenske arbejderbevægelses mænd har nydt godt af tilstrækkelig seriøs opmærksomhed, selv om en forfatter som Franz Osterroth har slidt bravt i det for at skabe en egentlig basis for den slesvig-holstenske arbejderbevægelses historie. Det er derfor både med interesse og tilfredshed, at man ser fremkomsten af en mindebog om en af efterkrigstidens slesvig-holstenske politikere af virkelig format, bogen om socialdemokraten Andreas Gayk.

Mindebogen omfatter 26 bidrag af folk, der har kendt ham, deriblandt personligheder som tidl. ministerpræsident Bruno Diekmann, professor Fritz Baade, professor Michael Freund og forvaltningseksperten og politikeren Dr. Hans Müthling.

Tillige har professor Kurt Jürgensen $i$ en introduktion til erindringskapitlerne om Andreas Gayk givet en både solid og nuanceret skildring af tiden efter 1945. I sin korthed giver dette introduktionskapitel både en god indforing i britisk besættelsespolitik og dennes 
indvirkninger på det slesvig-holstenske samfund og i den almindelige indenrigspolitiske udvikling i det tyske samfund.

Derunder skal det $\mathrm{i}$ forbifarten nævnes, at professor Kurt Jürgensen er en af de meget få tyske historikere og politologer, der gør sig seriøse anstrengelser for at få et mere afbalanceret syn på den danske bevægelse i Sydslesvig i de forskellige faser efter 1945. Det bør noteres, ikke mindst fordi man flere steder $\mathrm{i}$ resten af mindebogen finder ansatser til den traditionelle tysk-nationale historieopfattelses mangel på forståelse for "wie es eigentlich gewesen $\alpha$.

Det er let at være konstruktiv og positiv $i$ en periode, hvor alt går godt. Det var Andreas Gayks lod at måtte yde sit ypperste i de uden overdrivelse værst tænkelige situationer, i genopbygningsårene umiddelbart efter 1945.

Bogen giver et godt indtryk af, hvordan Andreas Gayk udviklede ikke blot den sejhed og styrke, som det lykkedes ham at overleve med gennem Weimarrepublik og Hitlerår, den giver også et godt indtryk af, hvor svært Gayk i grunden selv havde det de sidste àr før 1933, i Weimarrepublikkens sidste år, hvor nogle ville slås for Weimar, andre blot gik undergangen i møde. Andreas Gayk, krigsveteran, journalist, efter 1933 reprxsentant i medicinalvarer, var i tiden efter 1945 foregangsmand $i$ vxrket med at rydde op efter de andres beskidte arbejde. Det var ikke let at rydde op efter 12 års nazistisk ødelrggelse af det slesvig-holstenske samfund. Andreas Gayk spillede både som politisk organisator af den hårdt medtagne arbejderbevægelse, som erfaren kommunalpolitiker og som landspolitiker en bærende rolle $i$ det slesvig-holstenske SPD. Han var overborgmester i Kiel 1946-54 og kæmpede som sådan som en love for sin bys interesser. Han markerede sig ikke blot i Slesvig-Holsten, men over hele det besatte Tyskland, som en sej og hvas kritiker af allieret besæettelsespolitik i den udstrækning, han mente, at den allierede politik gik vitale tyske interesser for nær og f. eks. truede den materielle basis for det sprede demokratis udvikling. Gayk forte fra 1946 an i protestdemonstrationer, da briterne med stor energi sprengte eller afmonterede Kiels industrianlæg, ikke mindst skibsværfterne. Kiels borgere frygtede, at Kiel skulle reduceres til fiskerby.

Gayk var en udogmatisk lidenskabelig og temmelig hensynsles politiker. Han har en del af æren og ansvaret for, at tonen er blevet så kras i slesvig-holstensk politik, at landdagspolitikken er så barsk og bitter.

Andreas Gayk blev ikke ministerpræsident i den første socialdemokratiske landsregering (1947-50) i Slesvig-Holsten. Men han spillede en væsentlig rolle $i$ al dens politik, var en mægtig baggrundsfaktor.

Da SPD efter valget i 1950 gik i opposition, fortsatte han med at spille en rolle, i den udstrækning hans gradvist forværrede helbredssituation tillod det. 
Havde han ønsket det, kunne han have spillet en større politisk rolle, også på vesttysk forbundsplan. Men Gayk, der i sin tid havde foretrukket det nære, Kiels genopbygning og Kiel som politisk bastion, ønskede ikke at forlade sin regionale basis.

Det tyske politiske klima før og efter 1945 har sjxldent givet spillerum for større tolerance eller frisind, heller ikke hos de demokratiske tyskere. Det så man i tiden o. 1945 hos både tyske borgerlige og socialdemokrater $\mathrm{i}$ forhold til den danskorienterede bevægelse $\mathrm{i}$ Sydslesvig, de traditionelle tysk-nationale forsvarsmekanismer satte hurtigt ind.

Kapitlet Andreas Gayk og de dansk-tyske relationer er et afsnit for sig $i$ den danske og den tyske arbejderbevægelses historie, som langtfra er tilstrækkelig udforsket. Ernst Siegfried Hansens bidrag i mindebogen er ret beskedent, elegant formuleret, men lidet informativt. Det kan undre, at Ernst Siegfried Hansen ikke har benyttet lejligheden til at øse af sin rige viden og bl. a. fortælle lidt mere om Gayk og forholdet mellem SPD og SPF (de dansk-orienterede socialdemokrater i Sydslesvig).

Derimod ser man $i$ hans afsnit klart udviklingen fra Gayk som Schumachers nære kampfælle mod dansk separatisme i 1946 til den gradvise overgang mod en mere forsonlig holdning både over for SPF og den danskorienterede bevægelse. Gayk spillede en stor og fra alle sider meget anerkendt rolle, da der skulle skabes rygdxkning for Kiel-erklæringen.

Der savnes imidlertid en kølig erkendelse af Kiel-erklæringens faktiske betydning - eller rettere sagt mangel på samme. Læeser man Ernst Siegfried Hansens afsnit igennem, făr man nærmest indtryk af, at punktum på mindretalsproblemerne syd for græensen var sat $\mathrm{i}$ 1949, at Bonn-København-erklæringerne nærmest var senere formaliteter. Derved forbigås elegant, at Gayk også spillede en rolle som modstander af den smålige chikanepolitik under Fr. W. Lübke. "Andreas Gayk betød meget både for stabiliseringen af det slesvigholstenske samfund og styrkelsen af demokratiet «. Mindebogen her giver talrige facetter af ham $\mathrm{i}$ hans talrige gøremål. Den er ikke det sidste ord, men et værdigt bidrag til belysning af Andreas Gayk og hans rolle $\mathrm{i}$ den slesvig-holstenske arbejderbevægelse og det slesvigholstenske samfund.

Bogen er tillige påmindelse om, at vi trænger til at få mere at vide om de første 10-15 år i Slesvig-Holsten. Der kan siges mange kritiske ting om Slesvig-Holstens udvikling efter 1945, men det er værd at gøre opmærksom på, at rekonstruktionens mænd - fra Gayk til Lübke - gennemførte så mange og så betydningsfulde ting, at der er betydelige opgaver tilbage både for danske og tyske historikere. Anders Ture Lindstrøm 
Harboe Kardel: Grenzlandmelodie in Dur und Moll - Erlebnisse elnes Journalisten auf dem deutsch-dänischen Parkett

Karl Wachholtz Verlag. Neumünster 1975. 142 s., ill.

Da Manfred Spliedt sidste år udsendte sin udfordrende bog om det tyske mindretal "Sådan en dum knægt « (Gyldendal), kunne man have ventet en reaktion fra tysk side. Den udeblev.

Dr. Harboe Kardel, der i følge Spliedt og den danske særdomstol var én af de belastede dengang, kommer i sin erindringsbog ganske vist ind på nazificeringen af mindretallet, som han i sin egenskab af chefredaktør for »Nordschleswigsche Zeitung $\mathrm{i}$ den kritiske periode fulgte på nærmeste hold. Men han skal ikke beskyldes for at være fremkaldt af Spliedt. Hans bog forelå i manuskript, før "Sådan en dum knægt« udkom, og Kardel kan støtte sig til sine gennem 50 år førte dagbøger. Hans betragtninger er tilmed ganske upolemiske, og for så vidt angår fødselshjælpen for nazismen i Nordslesvig, kan de ikke på nogen måde tilfredsstille Spliedt eller for den sags skyld os andre. Det er bløde hvidevarer. Kardels erindringer blev straks ved udgivelsen mødt med nogle kritiske indlæg. De beskæf tigede sig mest med det, der ikke stod $\mathrm{i}$ bogen.

Men en mand, der skriver, at han hver dag har takket Gud, fordi han fik lov til at leve som journalist $i$ et grænseland, og at han altid har holdt mest af samvar, hvori både tyske og danske deltog, har naturligvis krav på at få sin levnedsbeskrivelse bedømt også efter andre kriterier end de rent politiske. Menneskeligt tegner bogen billedet af den wilhelminske studentikose type (»Oh, alte Burschenherrlichkeit«), der som en selvfølge meldte sig frivilligt ved krigsudbruddet i 1914, deltog i grænsekampen på tysk side - for så endnu engang i 1943 at trække i tysk uniform, nu ulykkeligvis som bevæbnet "Zeitfreiwillig « midt i det danske Åbenrå. Det var en »dialog« med andre, håndfaste midler. Muserne tav.

Harboe Kardel fødtes 1893 i det holstenske Nortorf som søn af en lærer, der år 1900 blev rektor for realskolen i Tønder. Han blev student i Husum og drog, som nævnt som ganske ung med artilleriet i felten, $i$ øvrigt imod faderens ønske. Efter krigen studerede Kardel $i$ Kiel, og med erhvervet doktorgrad blev han i 1922 medarbejder ved det af Ernst Schröder oprettede Korrespondenzbureau Nordschleswig. Kardel stiftede første gang bekendtskab med nationalsocialismen ved et møde $1924 \mathrm{i}$ Münchens $» B$ Bürgerbräukeller «. Taleren var general Erich Ludendorff. » Jeg var klar over, at der her blev drevet katastrofepolitik «. Det kan man kalde tidlig erkendelse, den skulle så blot have holdt sig lidt længere. Først nu, da det hele er overstået, tilstår forfatteren... »Også som medløber blev jeg medskyldig $i$ katastrofen, som til sidst rev hele folket i afgrunden «.

I 1927 sørgede den tyske folketingsmand i Nordslesvig, pastor 
Johs. Schmidt, Vodder, for, at Harboe Kardel blev redaktør af bladet "Neue Tondernsche Zeitung ", et blad, skriver han, som han fik lov til at forme ud fra sit eget, inderste vxsen, dvs. ved at tale helt personligt til læserne. *Jeg havde ingen personlig xrgerrighed. Jeg ville skrive, publicere, forarbejde det oplevede «.

Da Kardel i 1934 blev chefredaktør for Nordschleswigsche Zeitung « i Åbenrå, var han derimod fra starten »bundet til en ensrettet propagandas ledemotiver. Jeg ville gerne have skabt et bredt forum for alle meninger, men forholdene tillod det ikke«. Set med danske øjne når tilbageblikket her sit brændpunkt. Hvem var det, der »ensrettede " bladet? Hvor kom ordren fra $\mathrm{i}$ et frit land, der ikke kendte til pressecensur? Hvorfor kunne »alle meninger « ikke komme til orde $i$ et blad, der udkom $i$ et frit, demokratisk land? Hvordan gik det til, at frie mænd i Nordslesvig, der aldrig havde været bange for at tage bladet fra munden $\mathrm{i}$ forholdet til danske modstandere, nu lydigt underkastede sig den nazistiske udlandsorganisations $\gg$ hellige, ukrænkelige, love, der gjaldt i Brasilien på samme måde som i Nordslesvig«?

Desværre får læseren ikke svar på disse spørgsmål, når man da ser bort fra en oplysning om, at den egentlige leder af mindretalsbladet *N. Z. «, Ernst Schröder, Flensborg, der formidlede tilskuddene fra Tyskland, i 1938 kort og godt opløste bladets tilsynsråd på 13 medlemmer og indsatte et nyt på fire. Disse fire var: Ernst Schröder (formand), Rudolf Stehr (næstformand), lærer Ketel Jensen, Sønderborg, og gdr. Hans Fürsen, Åbenrå. Lærer Paul Gläser, Tønder, der hørte til de afskedigede, udbrod under forhandlingen opbragt: "Det er jo Schuschnigg-metoder! « Allerede i 1937 var der blevet grundlagt en afdeling for presse og propaganda under ledelse af Rudolf Stehr.

I det lange løb kunne Harboe Kardel heller ikke selv holde skansen. Det blæste koldt på nazismens tinder. Han blev som chefredaktør afløst af Ernst Siegfried Hansen. Det skal sikkert opfattes symbolsk, når Kardel nævner, at selv de gamle møbler i redaktionen blev smidt ud $\mathrm{i}$ gården »under de nye unge herrers reformiver “. Det har altså været et generationsskifte med appel! Kardel skrev $i$ sin sidste ledende artikel: „Vi vil igen bygge op, hvad krigen har ødelagt. Vi vil forsøge at nå til en ny forståelse«. Endvidere protesterede han, da Wilhelm Jürgensen ( $₫$ Asmus von der Heide«) prøvede at indkalde til en sørgefest efter Hitlers død. Efter 5. maj 1945 fulgte den ventede arrestation og idømmelse af fire års fængsel i Fårhuslejren. Her sætter bogen punktum.

Erindringerne i dur og moll kan især læses som et kildeskrift om de mange rivaliserende nazi-bevægelser i Nordslesvig, der først i 1938 ved magtbud syd fra blev samlet og ensrettet under dyrlæge Jens Møllers ledelse. Disse forhold er belyst af historikere ude fra, men får i Kardels personlige form en direkte tragisk karakter. Hans op- 
levelser i tiden 1933-1945 kunne som motto have haft Goethes ord fra "Troldmandens lærling «:

"De krafter, som jeg kaldte,

dem bliver jeg ej løs «.

Eskild Bram

Niels Bøgh Andersen: Feltdegn fra Harreslev Mark.

Gyldendal 1975, 261 sider, ill.

I sin første bog, Fiskersøn fra Aventoft, fastslog Bøgh Andersen som sin erfaring, at hans fantasi kom $\mathrm{i}$ bevægelse, når han kom ud for noget uforståeligt. I sin nye bog supplerer han denne erkendelse med en bemxrkning om sin medfødte nysgerrighed. Og hvad enten han under sin deltagelse $\mathrm{i}$ den anden verdenskrig har mødt noget, han ikke forstod eller noget, der vakte hans nysgerrighed, skal det siges, at begge dele har været forudsætningen for, at skildringerne af hans personlige oplevelser er blevet så levende og interessante.

Han blev på session taget som infanterist, skønt han var platfodet og havde et ikke særlig godt hjerte. Det må alligevel have været godt, om end på en helt anden måde end Topelius' Svend Duva's, for det kom ud for adskillige strabadser og nerveoprivende oplevelser. Han havde efter uddannelsen i Memel den lykke at blive divisionspræstens medhjxlper, eller som han selv kalder sig: "feltdegn «. Derved fik han lejlighed til at betragte krigen lidt mere fra kulisserne end den almindelige frontsoldat. Krigens gang så han ud fra sin egen opfattelse og sin egen private strategi. Det blev til et væld af iagttagelser $o g$ til personlige refleksioner. Men det medførte også, at han lærte land og folk at kende indenfor de spredte egne, krigen førte ham til. Så mangfoldige er hans oplevelser, at det vil være umuligt $i$ hans meget brede fortalleform at følge ham fra sted til sted.

Vi følger ham fra en mellemstation i Frankrig til Rusland, til begivenhederne under tilbagetoget fra Moskva, til oplevelser i skyttegraven, fra den ene forlægning til den anden, til Ukraine, og da det store nederlag ligger klart for dagen, over Polen tilbage til vestfronten, hvor han bliver taget til fange og overføres til England. Fra hvert sted har han meget at fortalle, om folk han modte og alt, han fik øje på. Fra opholdet i russiske landsbyer har han skildret bondefolkets tænke- og væremåde og sit forhold til menneskene overordentlig interessant. Han lærte sig selv nogenlunde at beherske det russiske sprog, at glxde sig over landskabelige skønheder og siger, at han har ladet et stykke af sit hjerte blive $\mathrm{i}$ Rusland. For den sags skyld kunne hans bog godt blive oversat til russisk.

Man har, men ganske fejlagtigt, villet sammenligne Bøgh Andersen med »den gode soldat Svejk«. Det er han en alt for god iagttager 
til, selv om han som »feltpræst « og på sine ture i "Himmelvognen" sammen med sin gode ven Hannes har drevet det vidt på egen hånd og har "rekvireret «, hvad der var brug for til husbehov. Det gxlder også hesten »Peter«. Om den siger han, at den har frelst hans liv, bl. a. når den ud fra en sjette sans nægtede at fortsætte, når faren truede. Under tilbagetog satte den derimod farten op.

Bøgh Andersen var, som han skriver, 21/2 år $\mathrm{i}$ kirkelig krigstjeneste, men krigen var ikke hans krig. Hans indsats var afhængig af, hvor han kunne få sig selv placeret, for det gjaldt om at slippe levende hjem. Feltpræsten var en servil nazist. Bøgh Andersen, der ellers hadede nazister, kom dog helt godt ud af det med ham, men forsvandt under hans dårlige prædikener. Han undskyldte sig med, at han nødig ville miste den sidste rest af sin barnetro.

Han mødte både nazigale og respektable tyske officerer, navnlig satte han pris på divisionsgeneralen, der gjorde alt for at hindre jødeprogromer. Engang bad generalen ham fra Flensborg Avis oversætte, hvad bladet skrev om krigen. Det blev til, hvad Bogh Andersen havde hørt $\mathrm{i}$ den udenlandske radio, som han lyttede flittigt til. I øvrigt havde han respekt for en kreds af gamle projsiske officerer, som søgte at hindre de frygtelige ugerninger, der blev begået i Rusland, både mod jøder og mod befolkningen. Det må være noget af et mirakel, at Begh Andersen slap fra at true en tysk officer med sin revolver og kaldte ham et svin, fordi han behandlede en flygtning brutalt.

Så var der partisanerne, som ingen var sikre for, og så var det alligevel dem, der sørgede for, at degnen fik sit kirkealter, som han havde mistet under flugten på midtfronten, sendt til Ukraine. Det er blot en enkelt ting af mange mærkelige tildragelser $\mathrm{i}$ bogen, som sammen med de talrige iagttagelser og rammende associationer gør den så indholdsrig, at der er stof nok til en halv snes romaner. Dertil kommer Bøgh Andersens interesse for kunstværker af enhver art, som han har en vis sporsans for at kunne opdage overalt. Flere af de tegninger, bogen indeholder, viser desuden, at han på dette område er kunstner.

I marts 1944 kom Bøgh Andersens stab og dermed også dens krigskirkelige afdeling til Danmark. I de få måneder, den var indkvarteret på Bramminge-egnen, fik han lejlighed til at besøge 30 kirkesogne $i$ Syd- og Sønderjylland og være med til tysk gudstjeneste i dansk kirke. Da han talte dansk, var egnens folk mistroiske over for ham, indtil de fik at vide, at han var dansk sydslesviger. Han fik mange gode venner og bekendte, men måtte også vogte sig for stikkere og for Gestapo. Herom har han adskilligt at fortælle, bl. a. også om sin forbindelse med modstandsbevægelsen.

Det blev på flere måder et bevæget ophold i Danmark. 1. maj var han $\mathrm{i}$ Ábenrå med til at begrave 7 engelske flyvere og mødte ved 
den lejlighed den tyske sognepræst pastor Beuck, der, da han hørte, Bøgh Andersen var dansk sydslesviger, udtalte $\gg$ Gott beschütze Sie und bewahre Sie«. Men en måned senere var det slut med tiden i Danmark. Vejen gik nu over Belgien, Holland til Normandiet. Herom har Bøgh Andersen adskilligt interessant og spændende at fortalle, inden krigstjenesten for hans vedkommende blev afsluttet. Den 16. juli 1944 blev han i Villedieu ved Chambois taget til fange af cubansk-amerikanske soldater. Det første skridt på vej mod England var taget, og dermed var hans forventning sket fyldest. Først måtte han dog igennem forskellige fangelejre, og her havde man ingen forståelse for, at en dansk sydslesviger var i tysk uniform. Først da han fortalte, at han $1934 \mathrm{i}$ Kensington Garden havde kysset en engelsk sygeplejerske, hjalp det med forståelsen. Det kneb dog stadig med at fă den engelske skepsis fjernet. Først efter mange besværligheder og ved hjælp af Special Forces' danske medlemmer lykkedes det at fă ham på fri fod og iklædt som civilist. I den følgende tid blev han indlemmet $i$ den kreds af danske $i$ London, som var optaget af, hvordan forholdene i grænselandet og Europa skulle ordnes ef ter det forventede tyske nederlag. Det er et kapitel for sig, som har krav på en mere prxcis historisk redegørelse. Et enkelt, som vi nu kan se, dilettantisk forslag, gik ud på, at Kieler-kanalen skulle stilles under allieret eller dansk kontrol med Danmarks ret til at kræve en senere nyordning af landet ned til Dannevirke. Det blev Special Forces danske medlemmers program, som Bøgh Andersen hverken kunne sige ja eller nej til, måske fordi han havde fået fornemmelse af, hvorledes England endelig ville stille sig til det. Udenrigspolitik er nu engang ikke hvermands sag.

Under resten af krigen måtte han blive i England. Først fem dage efter Danmarks befrielse var han hjemme i Sydslesvig igen.

\section{Morten Kamphövener}

Peter Beck: Ung mand fra Sundeved.

Udgivet af Historisk Samfund for Sonderjylland 1975. 127 sider, ill.

I en ny erindringsbog har lektor Peter Beck igen fortalt om sin barndom og ungdom. Han kalder sin bog Ung mand fra Sundeved, men det er nok den gamle Beck, der har fremkaldt minder og oplevelser, som har fulgt ham livet igennem og har holdt sig lige så friske som levende. Han er en god iagttager med ore for det særprægede $i$ tale, væsen og væremåde. Her ud fra har han givet et sundevedsk kulturhistorisk bidrag af stor værdi. Han fortæller uden videre hensyn til stilkunst og andre æstetiske sædvaner, frisk og ligefrem, og det har sikkert været ham ubevidst, at det netop har givet skildringen særlig værd. 
At det er gået lidt ud over kompositionen, kan falde ind under samme vurdering. Men det kan ikke hindre en kritisk bemærkning om, at de nye erindringer om barndoms- og ungdomsminderne burde være bragt sammen med skildringerne i det forste bind, eller måske indføjet i disse. Det kan udgiveren måske bære medansvaret for, men derved kommer de mere personlige optegnelser om hans skoletid $\mathrm{i}$ Kolding og Sønderborg og studentertiden $i$ København til at stå som et appendiks til det Sundeved, der stadig lever så stærkt $i$ hans bevidsthed. Alligevel vil skildringen af studieårene $\mathrm{i}$ København blive stående som et godt udtryk for en ung sønderjysk bondesøns oplevelser under helt andre forhold. Han fortæller om mennesker, han har mødt, om oplevelser, om medstuderende og professorer, af hvilke Vilhelm Andersen har gjort stærkest indtryk på ham. Dette afsnit burde nok vare bragt sammen med erindringerne fra hans tid som larer ved Tarm gymnasium, som er udgivet fra et andet forlag.

$\mathrm{Nu}$ læser man imidlertid med særlig interesse om overgangstiden fra tysk til dansk styre med deres besværligheder og mærkværdigheder, ændrede forhold med omstilling på mange måder, valutamæssige og meget andet. Nogle vil måske undre sig over, de primitive, nøjsomme forhold almuen levede under så sent som 1906, ja helt op til genforeningen, selv om den var godt okonomisk funderet. Efter genforeningen gjorde der sig i så henseende nye forhold med driftsxndringer og tekniske forbedringer gældende. Damptærskværkernes tid var forbi. Det får Beck til at mindes installationen af et sådant, da maskinbyggeren beklagede, at hans dygtige svend på grund af sygdom ikke kunne hjælpe til. Han hed Jes Christiansen og blev senere direktør for Sønderjyllands Højspændingsværk.

Nøjsomhed med gudsfrygt er en vinding, sagde Paulus, og den regel blev også fulgt $\mathrm{i}$ Ullerup. Ikke blot fordi morgenmaden på en gård bestod af boghvedegrød. Dermed fulgte dyrkning af boghveden, der blev "snurret « $i$ toppen. Beck har endnu dens fine duft i næsen og de nektarsøgende biers summen $\mathrm{i}$ oret. Men under disse forhold herskede der, trods nøjsomhed, et jævnt og muntert liv. Familierne blev opdraget til fornuftig sparsommelighed. Stina Kjær advarede mod at prale af folk, da de så blev "føje», d. v. s. storpralende. Selv levede hun beskedent $i$ et lille hus, efter at hun havde bortforpagtet en gård, hun havde arvet. Hun var godgørende og døde som sognets rigeste pige, efterladende sig en formue på op mod $800,000 \mathrm{kr}$.

Lektor Beck holder naturligvis af det sundevedske folkemål, og det hænger til gengæld ved ham. Hvis man ikke ved, hvad wet jet " er, forklarer han, at det er et eller en til. Stor visdom ligger der også $i$ ordene: »Gammel klogge å pigge skal en væ fåsægte med «. Man kan levende forestille sig kromand Hans Norn, som han skildres, siddende ene $i$ sin krostue med piben $i$ munden, og på den tyske andenlærer Fr. Christensens (den senere bibliotekar og hjemstavnsfor- 
sker) spørgsmål om han hos ham kunne få sin daglige »unnen «, stak hovedet frem over avisen med ordene: „De må do snak me $x$ kvindfolk om «.

Så lille Ullerup var, er verden ikke større. Den tyske kommuneforstanders søn kom til postvæsenet og kom som postmand med på kejser Wilhelms Norgestogt. Han endte som postmester helt nede i det holstenske. Og hvad med Ole Nilsson i Egernsund? Han var fra Växjö i Småland. Hans ældre halvsøster er Christina Nilsson, den verdensberømte svenske nattergal!

Det var dengang alt det, Peter Beck har fortalt om, men det vil hos mange blive til en genoplevelse $i$ erindringen, selv om meget, ogsa $i$ de ydre forhold, er blevet anderledes. Ullerup bys bagside er blevet til forside, men kirken ligger der endnu, omgivet af gårde og huse. Sognets anden kirke fandtes i det nu forsvundne Philipsborg. Sådan hvisker historien i krogene, og lektor Beck har meget at fortæelle med forståelse for det særprægede i væremåde og tonefald.

Som i historien om Peter Chr. Hanssen, der var sendt til Ullerup for at fange frøer i morbroder Johan Iversens dam. Turen foregik til søs med fjorddamperen »Rota«. På hjemvejen gik han ned $\mathrm{i}$ kahytten og efterlod spanden med frøerne på dxkket. Men da »Rota « kom i slinger ved Varnæshoved, væltede spanden, og frøerne hoppede rundt på dxkket, hvilket foranledigede styrmand Møller til at råbe ned i kahytten: "Ven $x$ de, d $x$ rejse m $x$ pajde? «

Det er både hørt og set! Og sådan er alle de små morsomme træk i denne bog, karakteristiske og fornøjelige.

Morten Kamphövener 


\section{Bognyt}

Historikeren Aage Friis 1870-1949. Privatarkiv, historiske samlinger og bibliografi. Foreløbige arkivregistraturer, ny serle nr. 11.

Udgivet af Rigsarkivet 1975. $119+65$ s.

På Rigsarkivet i København findes foruden en række fremtrædende sønderjyders privatarkiver flere andre personarkiver af betydning for sønderjysk historie. Et af de vigtigste heraf er nok professor Aage Friis' meget store arkiv, for Friis havde både før og efter genforeningen stor indflydelse på det nationale arbejde. Han har ført en omfattende korrespondance bl. a. med en større personkreds i Sønderjylland, som det fremgår af registraturens brevskriverfortegnelse. Denne skæmmes forøvrigt noget af flere fejl i navnene og ufuldstændige identificeringer for de sønderjyske korrespondenters vedkommende.

Forhåbentlig vil der snart blive udgivet flere registraturer over Rigsarkivets personarkiver af interesse for Sonderjyllands historie, f. eks. over Regenburgs og $\mathrm{H}$. V. Clausens privatarkiver.

D. A.

Det radikale Venstre 1903 - ca. 1959. Foreløbige arkivregistraturer, ny serle nr. 10.

Udgivet af Rigsarkivet $1975.82 \mathrm{~s}$.

For første gang er der udsendt en registratur over et af de vigtigste politiske partiers arkiver, nemlig Det radikale Venstres. Partiet har afleveret et righoldigt arkiv til Rigsarkivet og dermed et væsentligt kildemateriale til Danmarks nyere politiske historie, herunder i ovrigt også materiale vedr. det politiske arbejde på lokalt plan. Adgangstilladelse til arkivet kan søges gennem partisekretæren.

D. $A$. 
Privatarkiver. Redaktør, folketingsmand Anders Lebeck (1869-1926) og Redaktør, folketingsmand A. Svensson (død 1963).

Foreløbige arkivregistranter, udgivet af Landsarkivet for de sønderjyske Landsdele, Abenrå 1976, henholdsvis 25 s. og 51 s., dupl.

Det er to af de spendende privatarkiver, der herved åbnes et indblik $i$. Det fremgår, at $\mathrm{A}$. Svensson som venteligt har ført en sæerdeles omfattende korrespondance om de nationale forhold før og efter genforeningen. Hans skiftende pressetilhørsforhold og hans folketingsarbejde afspejler sig i korrespondancen, der også rummer væsentlige afsnit om arbejdet med den konservative højskole på Hindsgavl. Der er et betydeligt stof til belysning af forholdet til Christmas Møller, dennes stilling til det sydslesvigske sporgsmål efter $1945 \mathrm{og}$ forholdene omkring hans opstilling som losgæenger ved folketingsvalget i 1947.

Anders Lebeck var kasserer for Skoleforeningen fra 1911 til sin død 1926. En del af arkivalierne er overført til Skoleforeningens arkiv, men det $\mathrm{i}$ fortegnelsen optagne stof vidner om den nære tilknytning til efterskolens og højskolens folk. Redaktørperioderne ved Hejmdal og Dannevirke afspejler sig, hans tid som folketingsmand for Venstre i Abenråkredsen (1920-24) ligeledes. Størst interesse må nok knytte sig til nr. 2753, der rummer resultaterne af omfattende sogneundersøgelser vedrørende ejendomme, ejernes okonomiske forhold og nationale sindelag, udført $\mathrm{i}$ tiden 1924-26, en pendant til H. V. Clausens undersogelser fra tiden for 1. verdenskrig.

Assistent Inger Biehl Hansen og stud. mag. Peter Keller Hansen har udført arkivfortegnelserne under tilsyn af landsarkivaren. Sådanne fortegnelser skærper appetitten, men mætter den ikke i samme omgang. Der er 80 års ventetid på privatarkivers stof, hvis ikke særlig tilladelse til benyttelse opnås.

K. $F$.

\section{MInlstermødeprotokol 1908-1909.}

Konseilpræsident Niels Neergaards referater ved Tage Kaarsted. Skrifter udgivet af Jysk Selskab for Historie. Universitetsforlaget i Aarhus 1975. $44 \mathrm{s.}$

I indledningen til denne lille publikation understreger professor Kaarsted, at mens de officielle statsrådsmøder refereres særdeles omhyggeligt, er de reelt langt mere betydningsfulde ministermøder kun sporadisk refereret. Kaarsted har tidligere udgivet kirkeminister Th. Povlsens referater fra tiden 1916-1918 og bebuder udgivelse af protokoller fra 1923-1924 og igen fra 1929. I protokolatet fra dette Niels Neergaards forste ministerium ses sønderjyske forhold kun behandlet én gang, nemlig 8. marts 1909: »Udenrigsministeren gav meddelelse om den sidste udvikling i Sønderjyl- 
land og dertil knyttede forhold.« Det må skønnes at være eftervirkninger af Optantkonventionen og indre danske brydninger i Nordslesvig, udenrigsministeren, gesandt greve C. W. Ahlefeldt-Laurvig har redegjort for.

K. F.

\section{Kr. Bording: Dagbog over Danmarks forste soclaldemokratiske ministerium 1924-26. \\ Ved Karen Marie Olsen og Hans Sode-Madsen, Jysk Selskab for Historie 1976. $131 \mathrm{~s}$.}

Når man igennem en årrække har undervist i moderne Danmarkshistorie efter lærebøgers fremstilling - også i perioden 1924-26 - er det en charmerende oplevelse at få et kig ind bag kulisserne, sådan som de kortfattede notater fra landbrugsminister $\mathrm{Kr}$. Bordings hånd giver det fra ministermøderne $\mathrm{i}$ det første ministerium Stauning. Det er så meget mere fortjenstfuldt, at udgivelsen har fundet sted, som selve ministermødeprotokollen til nu ikke har været mulig at opspore. Man følger den førte politik fra april 1924 - december 1926 med dens tre tyngdepunkter: Valutakrise, arbejdsløshed og afrustningssag. Man funderer over, om personsager mon spiller samme rolle på ministermøder idag som da. Det er uforblommede oplysninger, der gives, og bl. a. undervisningsminister, fru Nina Bangs hang til politiske udnævnelser bekræftes gennem fremstillingen. Vanskelighederne med Det radikale Venstre som støtteparti træder klart frem. Af specielle sønderjyske problemer berøres undervejs: Afvandingen af Tøndermarsken (Bordings egen sag), specielle kreditydelser, Cornelius Petersen - sagen, hjæelp til fremskaffelse af boliger til tjenestemænd, specielt i Sonderborg, og spørgsmålet om bedre adgang for flensborgere til Kollundskoven. Der udvises på ministermøderne stor forsigtighed $\mathrm{i}$ forholdet til den tyske nabo, bl. a. i holdningen til Grænseforeningens ønsker. Man kan herudover glæde sig over at erfare, at restaureringen af fregatten "Jylland « var på ministermøde i 1925, og at $\mathrm{Kr}$. Bording som seriøst forslag til bekæmpelse af arbejdsløsheden anfører oprensning af Kildesøen i Dyrehaven. Bording synes meget objektiv i sine optegnelser; man fornemmer af og til en vis undren over for Nina Bangs og Steinckes fremfærd.

K. F.

Erik Skram: HInsides Græensen. Erindringer fra Sønderjylland efter 1864. Med forord og kommentarer af Inge Adriansen og Jorgen Slettebo.

Jul. Strandbergs Forlag 1976. 159 s., ill.

Forfatteren Erik Skrams skildringer fra Sønderjylland udkom oprindelig i 1888 og genudgives nu i fotografisk optryk, men desuden forsynet med et forklarende forord, kommentarer, register og en rakke illustrationer fra 
det 19. årh. Bogen indledes med et længere afsnit om forfatterens oplevelser som frivillig i krigen 1864; men motiveringen for genudgivelsen må først og fremmest findes $i$ de efterfølgende rejseskildringer fra den afståede landsdel, hvor der meddeles talrige iagttagelser, der kan have værdi for lokalhistorikeren isxr på grund af de kulturhistoriske oplysninger. Det er da også det kulturhistoriske og topografiske, som udgiverne særlig interesserer sig for $\mathrm{i}$ kommentaren, hvor det egentlige historiske stof til gengxld behandles lovlig nonchalant. Det er således ikke rigtigt, at Istedløven blev ført til Danmark i 1920. Det skete først i 1945. Der var heller ikke et ubetinget dansk flertal i Flensborg ved rigsdagsvalget 1881. Det opnåedes ikke ved hovedvalget, men først ved omvalget og da takket være splittelse i den tyske lejr. Rigsdagsmand Junggreens borgerlige erhverv var ikke journalist, men tobaksfabrikant, o. s. v. Men Erik Skrams tekst klarer sig også udmærket uden kommentarer, og denne smukt udstyrede genudgivelse vil utvivlsomt være til glæde for mange.

D. $A$.

\section{Helie Askgaard: En fabrik og dens omgivelser.}

Serien Samfundsgeografi. Gyldendal 1975. 44 s., ill.

Helle Askgaard, der bl. a. vil være sønderjyske læsere bekendt for sin bog Den sønderjyske industris udvikling 1920-1970 og for sit vasentlige bidrag til værket om Sønderjyllands Højspændingsværk 1922-72, har nu forfattet ovennævnte larebog om Danfoss og udviklingen i Nordborg kommune til brug for geografiundervisningen i gymnasier og på seminarier. Selv om det pædagogiske sigte er det helt overordnede $\mathrm{i}$ bogen med indlæring af bestemte arbejdsmetoder og begreber, der kræves i læseplanerne, vil bogen dog nok have interesse for både den lokalhistoriske og alment samfundsinteresserede læser. Trods al nøgternhed får »eventyret« om Danfoss også sin plads $\mathrm{i}$ bogen $\mathrm{i}$ tekst og illustration: Mads Clausen ene mand 1933-35, 4 ansatte i 1935, 40 i 1940 og godt 6000 i 1975. Det gamle spergsmål om det hensigtsmæssige $i$, at Danmarks største industrivirksomhed ligger i Nordborg kommune rejses på ny. Side 33 skrives der: $\gg$ Den nxrmeste større by er stadig Sønderborg, der 1970 har næsten 30.000 indbyggere. Afstanden fra Sønderborg til København er i luftlinie $200 \mathrm{~km}$, ad landevejen $300 \mathrm{~km}$ og med jernbane $350 \mathrm{~km}$.* Det er jo en v $x$ ldig relevant oplysning i forbindelse med et verdensfirmas kommunikationsbehov!

K. F.

Jaruplund danske skole. $\mathbf{5 0}$ ár.

Jaruplund 1976. Redaktion: Chr. Karstoft, Kjeld Beck, Wilhelm Goldberg, Brenda Rudebeck. 48 s., ill.

Det er altid værdifuldt for den lokale kreds, når tilstande skildres og minder fastholdes ved et jubilxum som det ovenanforte. Men også i større 
sammenhæng har et sådant arbejde værdi. I dette lille hæfte offentliggøres således dagbogsblade og erindringer fra den første danske kursuslærer R. $H$. Thorling, der umiddelbart efter 1920 begyndte undervisningen $i$ dansk $i$ landmand og smørhandler Peter Clausens stue - børn om eftermiddagen, voksne om aftenen.

Undervisningen i selve den danske skole begyndte 2. 6. 1926 med frk. Amalie Rattenborg som larerinde. Nicolai Büchert fortæller levende om den første danske skoletid og analyserer samtidig den foregående tyske skolegang. Slæegterne Büchert og Budach talte både stærkt $i$ arbejdet for skolen og $\mathrm{i}$ elevflokken. Elisabeth Budach har fået plads for en lille skildring af sin far Peter Budach. Tidligere larere og elever fortæller gode trxk og giver vurderinger. Der peges således på, at Jaruplund idag i nogen udstrækning er blevet soveby for Flensborg, men også på, at dette nye hold kolonister er blevet godt modtaget af og har lxrt af de gamle slægter i sammenholdet om skolen. - Der er gode illustrationer med eksakte billedtekster.

K. F.

\section{Ruth og KaJ Sieverts: Das Stallergeschlecht Sieverts In Eiderstedt.}

Nordfriisk Instituut, Bredsted 1975. 131 s., dupl.

Udgivelsen af ovennæevnte studie er understøttet af Lauritz og Augusta Dahls Mindelegat II. Oversættelse fra det oprindelige danske manuskript er foretaget af Maria Hickmann, Flensborg. Bogen er tilegnet afdøde overdigegreve Johan Redlef Volquardsen.

Det drejer sig, som titlen angiver, om at belyse den sievertske slægts historie. Slægten beklædte stallerstillingen i Ejdersted i ubrudt række fra 1462 til 1578 og igen under Den store nordiske krig i årene 1705-1713, og herudover blev slægten en udbredt præsteslagt i området. Den satte $\mathrm{i}$ begge egenskaber sit klare mærke på kirkeinventar og prædikestole. Dens betydning på andre områder, bl. a. for digebygning og digevedligeholdelse belyses.

Bogen bygger på et meget betydeligt trykt stof og et stort arkivalsk materiale. Det er på god måde lykkedes at lade det vald af lokalhistoriske og slæg thistoriske oplysninger, der er at finde, træde ind i rigshistoriens og den europxiske histories sammenhæng. Med et udtryk af Poul Kürstein er det blevet en Danmarks-historie, set fra Ejdersted. -

Bogen vil være en god støtte for dem, der vil arbejde videre med den ejderstedske historie. Selv har forfatterægteparret udmontet dele af den og det øvrige materiale, det har samlet, $i$ en lang række grundige artikler $i$ sønderjyske dagblade i de senere år.

K. F. 


\section{Flensburg. $n$ Einst und Jetzt $\alpha$.}

Gesellschaft für Flensburger Stadtgeschichte. Flenborg 1975. 176 s.

Denne historiske billedbog indeholder 202 Flensborgbilleder, hovedsagelig fra tiden efter 1864. Den er bl. a. ment som et billedsupplement til to af selskabets tidligere udgivelser, nemlig Flensborg-historien Flensburg - Geschichte einer Grenzstadt og kildesamlingen Flensburg in Geschichte und Gegenwart, og billederne er hyppigt forsynet med henvisninger til disse to varker. Derudover er det bogens formål at vise, hvorledes byen har forandret udseende under industrialiseringsprocessen og at vise de endnu bevarede typiske gamle gadebilleder, der stadig udgør en del af byens identitet og miljø. Dette formål varetages især i afsnittet om Flensborgs gader dengang og nu, hvor motiverne illustreres med flere billeder fra forskellige tidsaldre. Det er nok bogens mest vellykkede afsnit, og det viser, hvor hårdt udviklingen er gået ud over mange bevaringsværdige miljøer, hvoraf nogle endog er totalt forsvundet. Forhåbentlig vil denne bog bidrage til at skærpe interessen for at bevare det værdifuldeste af det tiloversblevne.

Mere diskutabel forekommer det sidste afsnit Ereignisse im Bild, et forsøg på at lave en lille historisk billedbog for tiden fra 1830 til idag i form af et supplement til illustrationerne i Flensborghistorien. Her bringes mange spæendende billeder, hvis publicering for så vidt er velfortjent. Dog er udvalget ikke omfattende og representativt nok til, at det er blevet en dxkkende historisk billedbog, hvilket måske heller ikke har været udgivernes tanke. Fra et dansk synspunkt kan billedudvalget og især flere af billedteksterne virke temmelig løjerlige. F. eks. kan man på s. 161 undre sig over, at når udgiverne gerne vil bringe et stemmetal for det danske mindretal fra Weimartiden, så anføres stemmetallet fra et rigsdagsvalg, som mindretallet $i$ stort omfang undlod at deltage $i$.

D. A.

\section{Nationalmuseets arbejdsmark 1975.}

208 sider, ill.

Arbogen rummer som altid levende og oplysende skildringer af de forskellige sider af Nationalmuseets virke. Et oploftende eksempel på, at det altid kan nytte, er tre artikler, der skildrer den utraditionelle bevaring af herregården Selsø. Stof fra herværende årbøgers arbejdsområde er ikke at notere - udover gengivelse af en herlig plakat fra Cirkus Beck-Olsens første optræden i Sønderborg efter genforeningen i artiklen $»$ Danske cirkusplakater i Nationalmuseet * af Ib Varnild.

K. F. 


\section{Guld fra Nordvestsjalland.}

Redigeret af Mogens Schou Jørgensen. Udgivet af Holbæk Amts Sparekasse $i$ anledning af sparekassens 150 års jubilæum. Kommission: Historisk Samfund for Holbæk amt. Holbæk 1975. 248 sider, ill.

Et sandt pragtverk med fornemme medarbejdere fra Glob til Piø! Kan kun tænkes fremsendt af Historisk Samfund for Holbak amt for at vakke grøn misundelse hos de øvrige samfund! Så meget guld er dog vist kun fundet i Nordvestsjalland, men det kommer så sandelig til sin ret i denne skildring og dens udstyr. Heldigvis rummer indeværende årgang af Sønderjyske Årbøger vidnesbyrd om, at også sønderjyske pengeinstitutter føler et ansvar over for det lokalhistoriske arbejde. Alligevel anbefales det specielt sparekasse- og bankdirektører, tilsynsrådsmedlemmer og repræsentantskabsmedlemmer at sætte sig ind i, hvad Holbæk Amts Sparekasse her har præsteret. 


\section{Noter og nyt}

\section{Søren Nissen}

Midt i vor glæde og den lettelse, der føltes her vesterude efter den overståede evakuering hin stormfulde lordag eftermiddag, den 3. januar 1976, modtog vi søndag morgen den triste efterretning, at en af de 22 ambu-

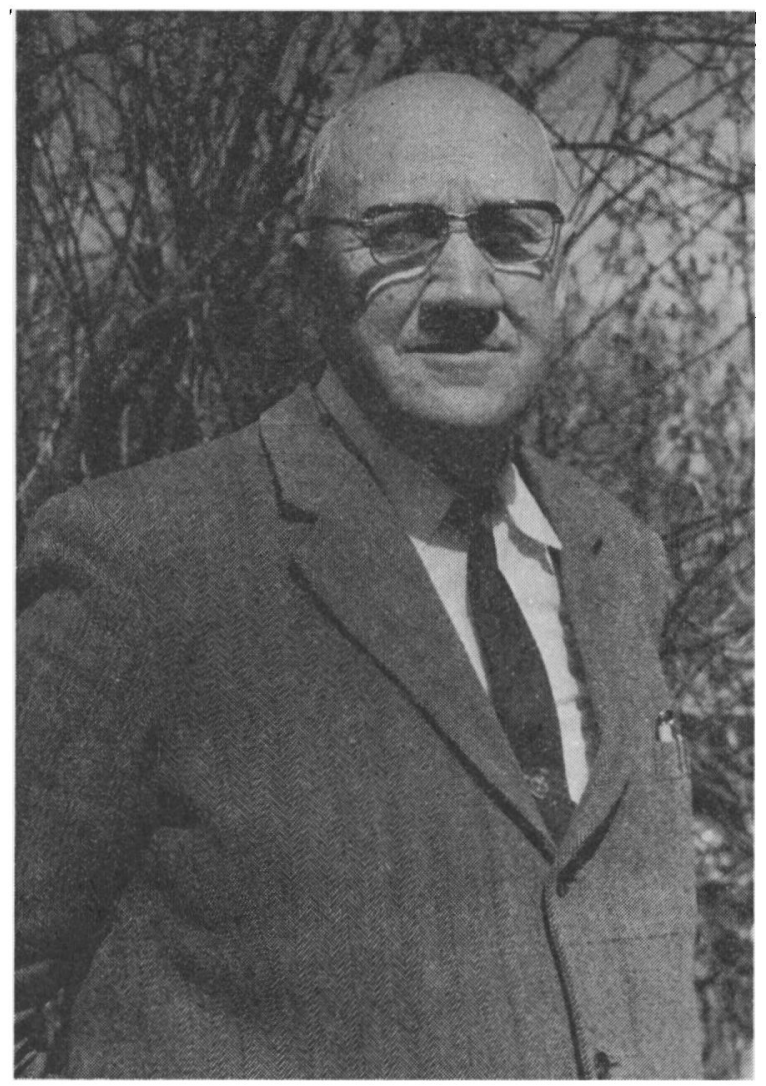

30.4. 1902-3.1.1976 
lancer, der skulle befordre patienterne fra Tønder sygehus til Haderslev på grund af det glatte føre havde været ude for et uheld i Skovby-krydset. Denne ulykke kom til at koste et menneskeliv. Det var forhenværende gårdejer Søren Nissen fra Harres, der efter en operation skulle ende sit liv på denne tragiske måde. Det berørte os på en smertelig måde, at denne så stoute og livskære mand skulle få en så brat afslutning på sit virksomme liv.

Søren Nissen var født den 30. april 1902 i Harres, og i denne lille landsby kom han til at ove sin indholdsrige manddomsgerning. Efter en uddannelse ved landbruget forpagtede han som 21-årig en gård, som han i 1928 overtog som selvejer. I en årrække var han bestyrelsesmedlem for Brede sogns ungdomsforening og forsamlingshuset, og uden for den snævre hjemkreds virkede han som vurderingsmand for Sønderjysk Kreditforening og blev medlem af representantskabet for Sydbank. Derved kom han i forbindelse med adskillige af egnens beboere, der lærte at sætte pris på ham. Det er dog navnlig for hans store lokalhistoriske interesse, han her skal mindes. Han udgav et hxfte »Min hjemstavn«, en skildring af det lille landsbysamfund, og udarbejdede sammen med Nicolai Svendsen og Cornelius Schmidt et skrift $\mathbf{i}$ anledning af Det blandede Distrikts Landboforenings 100 års jubilæum i 1954. I 1969 blev han formand for Tønder amtskreds under Historisk Samfund for Sønderjylland. Det lå ham altid stærkt på sinde rettidigt at få fastlagt et program for kredsens fremtidige arbejde, og han omfattede dette med en beundringsværdig troskab og interesse. Uden overdrivelse kan det siges, at $\mathrm{i}$ ham forenedes den vestslesvigske bondes bedste egenskaber, og dette skabte respekt for hans person og beundring for det store, uegennyttige arbejde, han ydede sin hjemegn.

Werner Christiansen

\section{Landsarkivet 1975}

Atter i 1975 kan der meldes om stigning i landsarkivets aktiviteter. Antallet af besøgende på læsesalen, der 1974 var 2676, steg 1975 til 2875. Den mindre nedgang i ekspeditionen til læsesalen fra 17419 i 1974 til 16489 i 1975 kan forklares med det stadigt voksende antal xerokopier af kirkebøger, som er anbragt på læsesalen, og som dennes gxster selv kan ekspedere sig i. Indlån af arkivalier fra andre arkiver er steget fra 71 enheder i 1974 til 179 i 1975 , medens udlanet til andre arkiver eller centralbibliotekers lasesale steg fra 424 enheder i 1974 til ikke mindre end 1121 enheder $i$ 1975. De ofte meget tidkrævende udlån af nye arkivalier til administrationen steg fra 54 enheder i 1974 til 63 enheder i 1975.

Den samlede tilvækst var 1975258 løbende hyldemeter mod 187 hyldemeter det foregående år. Af disse nye afleveringer skal især nævnes supplerende afleveringer til amts- og amtsrådsarkiver fra for 1970. Endvidere er Fårhuslejrens arkiv, og dele af vandbygningsvæsenets 5. distrikts arkiv, byudviklingsudvalgenes arkiver og af Tønder og Ảbenrå statsskolers arkiver 
blevet afleveret. Den største aflevering af statslig proveniens var fra politimesteren i Sønderborg. Også fra primærkommuner og kommunale institutioner er der sket ret omfattende afleveringer. Af afleveringer fra private institutioner kan nævnes: Sønderjyllands Kreditforening, Sprogforeningen, Aurillacforeningen, forskellige afdelinger fra Det unge Grænseværn og Danske Samfund, Broager Husflidsforening, Rødekro Borgerforening, diverse kvægavlsforeninger fra Haderslev osteramt og Rødding frimenighed (suppl.). Af personarkiver er blandt andet modtaget følgende: Strenderdeputeret H. C. Bladt, rektor i Nakskov Karl N. Bock, gårdejer i Asserballe Ernst Christensen, (suppl.), bankdirektør i Sønderborg H. Müller-Kristiansen, lærer i Broager August Korse, gårdejer i Kassø Jes Nielsen og hustru Amalie Nielsen (suppl.), samt gårdejer i Bovlund Marten Refslund Poulsen (suppl.). Af afleverede manuskripter kan nævnes rentier Holger Franks alfabetiske register til Østerlinnet kirkebøger 1735-1874 og forskellige af hans slægtstavler. Lærerægteparret M. og P. Høiers omfattende optegnelser vedrørende ejendommene $\mathrm{i}$ Klovtoft har landsarkivet fået tilladelse til at kopiere.

Arbejdet med udgivelsen af duplikerede arkivfortegnelser er fortsat med fortegnelserne over præstearkiverne i Tønder, Haderslev og Åbenrå provstier. Endvidere kunne fortegnelsen: Private Personarkiver udsendes. Disse arkivfortegnelser kan købes af interesserede for $15 \mathrm{kr}$. pr. stk. Under forberedelse var fortegnelsen over præstearkiver i Sønderborg provsti, over retsbetjentarkiverne og enkelte specialregistranter over private personark1ver, som udsendes 1976.

Lige som sidste år har Lærerhøjskolens afdeling i Haderslev holdt årskursus over emnet lokalhistorie i almenhistorisk perspektiv, og arkivar Jørgen Witte har efteråret 1975 ledet et af Historisk Samfund for Sønderjylland arrangeret vejledende kursus i slagtshistorisk arbejde.

Kortere kursus med landsarkivets arkivarer som vejledere har været afholdt for liniehold med historie som fag ved Tønder og Kolding seminarier og endvidere har der været 12 rundvisninger af foreninger. Foredragssalen har været benyttet til flere arrangementer, blandt andet films og lysbilledforevisninger, for medlemmer af Historisk Samfund for Sonderjylland, Ảbenrå byhistoriske Forening og Åbenrå Antikvitetsforening.

Til trods for den meget mærkbare nedskæring i bevillingerne lykkedes det også i 1975 i kortere perioder at kunne aflønne en studentermedhjxlper, hvilket har varet af betydning for at få historiestuderende til at gå i lag med sønderjyske specialeopgaver. Stud. mag. Peter Keller Hansen har 1975 ordnet og registreret redaktør Anders Lebecks privatarkiv. På konserveringsværkstedet har fru Christa Bomskov en kort tid hjulpet med papirkonservering, og Ernst Hinrichsen er fra 1. april ansat som medhjælper på konserveringsværkstedet.

Som noget ganske specielt skal endvidere nævnes, at d. 22. juli 1975 stiftedes amtskontorchef Viggo Florander og hustru Else Floranders legat. Den til enhver tid værende borgmester i Tønder, direktøren for Handels- 
bankens afdeling i Tender og landsarkivaren for de sønderjyske landsdele udgør bestyrelsen for fonden, hvis midler med tiden skal bruges til stotte for juridiske og historiske studerende og kandidater fra Sønderjylland, dog med fortrin for beboere i det tidligere Tønder amt. Legatet vil med tiden få en formue på et ottecifret tal.

P. K.J.

Historiske Samlinger for Senderjylland.

Se årsberetningen side 259.

\section{Studleafdelingen \\ 1975-76}

Året har været præget af en stigende aktivitet på studieafdelingens mange arbejdsområder.

Anders Ture Lindstrøms bog, "Landet Slesvig-Holstens politiske historie $i$ hovedtrxk 1945-54«, udkom i begyndelsen af oktober 1975. Den fik en pæn modtagelse i presse og tidsskrifter.

Tidl. kontorchef Lars Schubert har afsluttet indsamlingen af manuskripter til "Barn og ung i Flensborg *, fortsxttelsen til "Barn i Flensborg 18901920. (2. oplag 1973). Renskrivning af de sidste manuskripter og redaktion af billedmaterialet ventes afsluttet $i$ løbet af sommeren.

Tilsynsrådet har antaget et manuskript af Helmut Leckband til udgivelse, en slags fortsættelse på Krigsfangelazarettet i Tamanskajagaden * (2. oplag 1974).

Arbejdet med bogen om Egernførde er blevet fortsat.

Cand. phil. Carsten R. Mogensen, der har været stipendiat siden 1973, er i færd med at afslutte sin afhandling, *Tyskland og det danske mindretal i Sydslesvig 1933-1939«. Arkivar Dorrit Andersen, stipendiat siden 1.1. 1976, undersøger den sønderjyske arbejderbevægelses organisatoriske og politiske udvikling fra 1870 'erne til 1920. Bibliotekslektor Johann Runge har påbegyndt et manuskript til en Christian Paulsen-biografi. Skildringen vil være væsensforskellig fra dr. Runges afhandling fra 1969-70, der *kun « beskriver Chr. Paulsens politiske udvikling.

En rakke danske og tyske studerende har søgt og fået vejledning ved deres specialeopgaver, is $x$ r med hensyn til stofindsamling. Endvidere har danske og tyske lokalhistorikere trukket på Studieafdelingens og Centralbibliotekets muligheder for adgang til information $\mathrm{m}$. $\mathrm{v}$.

J. $R$.

\section{Haderslev museum}

Museets udgravningsvirksomhed blev i efteråret præget af de undersøgel- 


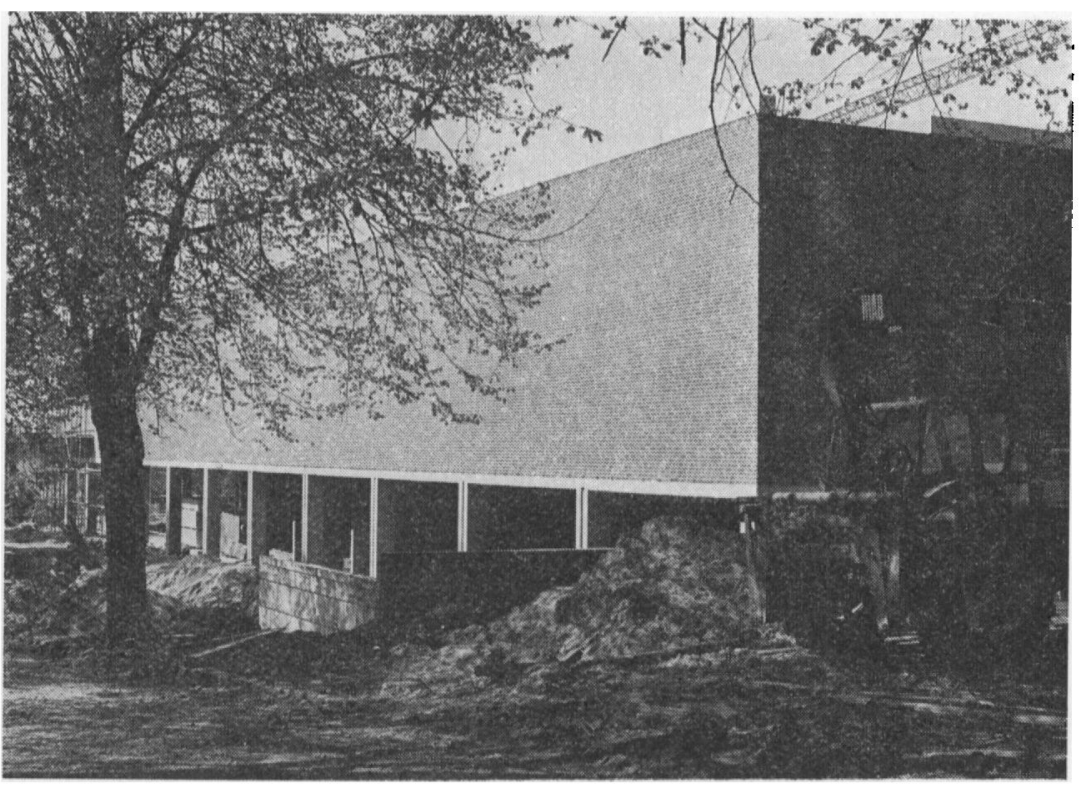

Den nye museumsbygning $i$ Haderslev under opforelse, maj 1976.

(H. H. Ratbje fot.)

ser, som anlægget af motorvejens sydligste stykke gav anledning til. Det kom til at dreje sig om en dobbelt langdysse ved Kiskelund og ved Froslev fire overpløjede gravhøje og en mindre urnegravplads, som var kommet til at ligge $i$ den $60 \mathrm{~m}$ brede vejbane. Af de 4 gravhøje var den ene interessant ved at indeholde hele 5 egekistebegravelser med rige bronzealderfund, deriblandt to spiralringe af guld. Interessant var også, at den forste af egekisterne ikke var begravet $i$ jorden, men stillet på en $60 \mathrm{~cm}$ høj sokkel af jord omgivet af en lodret kant af sten. Højen ligger tæt ved hærvejen, og her, ved alfar vej, har man på den måde stillet kisten til skue.

Efter endt konservering af fundene blev de vist ved en sxrudstilling $i$ Bov Sogns museum.

Den i 1974 påbegyndte udgravning af det store voldsted Nørrevold ved Arrild blev fortsat, og yderligere undersøgelse er planlagt til august 1976.

I Sdr. Ønlev blev undersøgt en overpløjet høj, der overraskede ved i sin midte at rumme ikke mindre end 6 grave, alle stammekistegrave, anbragt så tæt over hinanden, at de var vanskelige at skelne fra hinanden. En grav fra slutningen af stenalderen indeholdt et lerkar og flere ravperler, en noget yngre kvindegrav havde en ganske lille stammekiste stånde ved siden af sig, og den yngste grav indeholdt en bronzedolk fra bronzealderens begyn- 
delse. I nordsiden af højen fandtes to grave, den ene fra yngre bronzealder.

Der har været afholdt 3 foredrag i efteråret 1975 og to foredrag i lobet af foråret 1976, og af særudstillinger er foruden en kunstudstilling vist: „Vi bygger nyt museum «, »Min irske Arv « og »Frits Jürgensen i Haderslev «.

Den alt overskyggende begivenhed for museet er den nye bygning. Den skal foruden administrationen rumme en foredragssal, klasseværelse, cafeterie, konserveringsanstalt og atelier, studierum og bibliotek. Bygningen står nu i fuld størrelse og forventes afleveret i november.

H. N.

\section{Åbenrá museum}

Ảbenrå museum har i regnskabsåret 1974-75 haft en livlig udstillingsvirksomhed. Fra den 23.3.-8. 4. 1975 træsnit, atsninger, tegninger og skulpturer af Nikolaus Wehding og Preben Køie Nielsen. 15.4.-1.5.1975 Per Damm og Birthe Ohsten, motiver fra Færøerne, Lofoten og Grønland. 4. 5.18.5.1975 Nordisk uge, 5 finske grafikere, arrangeret af Sønderjyllands kunstmuseum og Åbenrå museum. 23.5.-8.6.1975. Grafik af Dea Trier Mørch. 23. 5.-1.6. 1975. Ảbenrå Nyhavns 50 års jubilæum, gamle fotografier og planer, arrangeret af Åbenrå havn. 23.5.-8.6. 1975. Papirklip af fru Ingrid Fleischer, Ảbenrå. 14.6.-30.6.1975. Malerier og tegninger af Christian Günther Hansen, Felstedskov. 1.7.-13.7. 1975. Canada-uge, fotoudstilling med canadiske vinterbilleder og børnetegninger. 17. 7.-15.9. 1975. Grønlandsudstilling. Samlingen udlånt af glarmester Søren Madsen, Tinglev. 9. 8.-15. 9. 1975. "Hvad Gravhøjen gemte« udstilling arrangeret af Åbenrå museum. 30.8.-28.9.1975 »En svensk buket «, værker udlånt af Carl Gruvemann, Ảbenrå. 5. 10.-26. 10. 1975. 5 svenske piger og en rose, kunstudstilling fra Sønderjyllands kunstmuseum. 1.11.-29.11. 1975. Dansk Britisk Club, engelsk kunst. 7.11.-30.11. 1975. Håndarbejdsudstilling. 28.11.-7.12.1975. U-landsudstilling, Salgsudstilling, arrangeret af St. Georgsgilderne. 6. 12.-31. 12.1975. Fotoudstilling »Gruppe 75«. 10.12.8. 1. 1976. Legetøj, udlånt af Svend Aage Faaborg og Arne Pedersen. 10. 1.25. 1. 1976. Kunstudstilling af Albert Køie-Nielsen. 31. 1.-15. 2. 1976. Viceskoleinspektør Jørgen Stave og fru Olga Wistisen udstiller malerier, grafik, tegninger og akvareller samt keramik. 6.3,-28.3.1976. Fotoudstilling, fotograf Svend Geerthsen udstiller gamle fotografier fra Abenrå.

Åbenrå museum har atter $\mathrm{i}$ år kunnet glæde sig ved at få mange gaver, hvoriblandt nogle særdeles værdifulde. Et skibsbillede af briggen "Diana«, sejlende for den grønlandske handel, ført af kaptajn Jes Jansen, født i Barsmark og et maleri af den samme, et smukt fransk taffelur og mange andre gode ting. Ved køb har man erhvervet et stort tinfad af en Ābenråtingyder J. Steincke med tydeligt stempel, en stor sjaldenhed og et smukt sølvhovedvandsæg med flusser af Chr. Waidløv Møller, der fik borgerskab i 1854 i Åbenrå. En smuk skibsmodel af Åbenrå-damperen "Delta« 


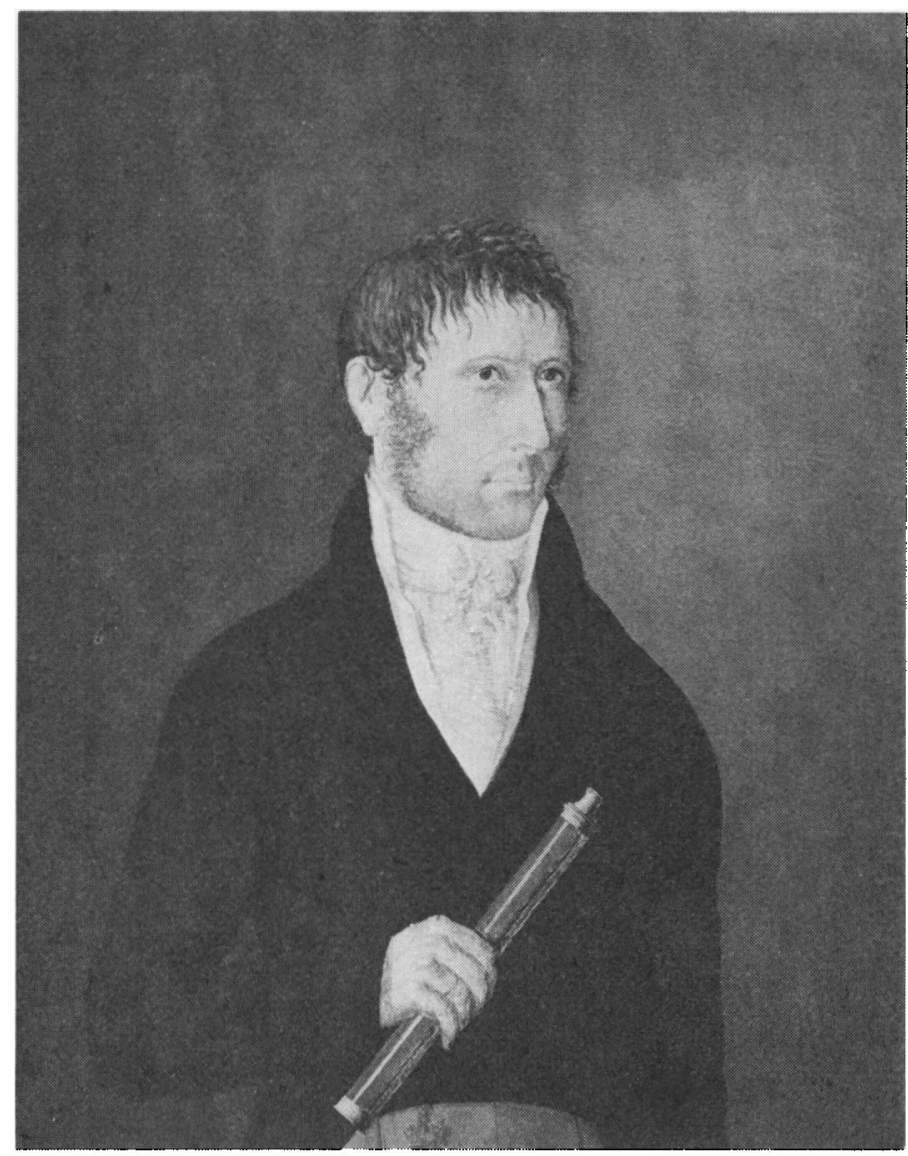

Billede af kaptajn Jes Jansen, Bodum ved Abenra, født 1783 i Barsmark. Kaptajn pa briggen .Diana af København. Den Kgl. gronlandske handel. (Gave fra fru Elisabetb Clausen, Rødding).

hører også til de gaver, museet har været særdeles glad for, da søfart jo er museets speciale. Carl Gruveman har af sin berømte samling skænket museet et udkast til en mosaikrude i Gøteborg kirke af Einar Forseth, "Korsbæreren «. Trods den gode sommer holdt besøgstallet sig på det samme, nemlig 13.844 personer.

$$
\text { H. J. }
$$

\section{Museat pá Sanderborg slot}

Museets besøgstal 1975/76 var ialt ca. 71.000 , en beskeden netto-fremgang 
på ca. 1.000 gæster. Dette tal dxkker imidlertid over en mærkbar forøgelse $i$ antallet af lokale skolebesøg og af større grupper, mens antallet af sommerturister, vel sagtens på grund af det varme vejr, var lavere end året før. Skolebesøget viser samtidig en jævnere spredning på forårs- og efterårsmånederne, men det har stadig en tilbøjelighed til at samle sig om tirsdage og onsdage $i$ en sådan grad, at det kniber at få plads til alle. Forudbestilling for skoler og grupper er nu en nødvendighed, for at museet kan klare omvisningerne.

Den endelige overenskomst mellem staten og Museet på Sønderborg slot om museets anvendelse af slottet er nu godkendt og underskrevet af boligministeren, amtsborgmesteren, Sanderborgs borgmester og museets formand. Det særlige udvalg, der $\mathrm{i}$ henhold til denne overenskomst skal administrere den særlige brug af slotslokalerne« $i$ nordfløjen, er derefter nedsat. Det kom til at bestå af direktør Tage G. Sørensen, boligministeriet, borgmester Harry Christensen, Sønderborg og museets formand, amtsrådsmedlem fru Ruth Nielsen. Museumsinspektøren fungerer som udvalgets sekretær.

Årets store begivenhed var åbningen af nyopstillingens 1. etape. Den officielle åbning med representanter for amts- og byråd, for museets bestyrelse og for håndværkere og med talrige gæster, fandt sted d. 31. oktober. Museets formand, fru Ruth Nielsen, holdt åbningstalen i slottets smukke drabantsal, museets hovedindgang. Derpå forevistes den nye bygningshistoriske afdeling, hvor slottets historie fortxlles i 11 tekst- og billedplancher samt 4 bygningsmodeller, mens en rakke fund fra slotsområdet og bygningsdele også er udstillede. Dernæst fortsattes til undervisningsafdelingen med den store, moderne skolestue og med studierum - det var dog især rummet med skolehistorisk samling og det gamle inventar, der vakte interesse. $P a ̊ 1$. sal fremvistes derpå rummene for middelalder og renaissance, hvor især den smukke opstilling af kirkefigurer fra slesvigske kirker var genstand for stor beundring. A bningen sluttede med et beskedent traktement i museets nyindrettede slotskøkken.

I oktober-november vistes sxrudstillingen $*$ Vold og Borg $*$, der fyldte en rakke lokaler på 1. sal i sydfløjen. Udstillingen, der var udført af Forhistorisk Museum, Moesgaard, var velbesøgt. I tilknytning hertil arrangerede museet og Historisk Samfund for Als og Sundeved en foredragsrakke, hvor professor Olaf Olsen, museumsinspektor H. J. Madsen og lektor Else Roesdahl, alle Århus, holdt foredrag om vikingetiden. Foredragene var sxrdeles velbesøgte med over 150 deltagere hver gang.

Som vanligt har museet modtaget en rakke gaver og foretaget en del indkøb. Fra fru $\mathrm{H}$. Mundts arvinger har museet som gave modtaget bl. a. to malerier, udført af fru Mundt, og en sofa. Som gave fra Ny Carlsbergfondet er modtaget et maleri af Jeppe Madsen Ohlsen, og Maria Lüders Hansen har skæenket et litografi, ligesom museet har købt endnu et litografi af denne kunstner. Med statte fra Ny Carlsbergfonder har museet desuden købt et maleri af C. W. Eckersberg: "Luftstudie med marine* og en collage af Franziska Clausen. Til tekstilsamlingen er modtaget meget omfattende 
samlinger fra frk. Karen Withen og fra fru Anna Hald Terkelsen - sidstnævnte en restaflevering fra \$Sønderjysk Hjemmevæv.« Både af tekstiler og redskaber er iøvrigt indgået adskillige gaver. Blandt disse kan nævnes biskop Jørgen Hansens bispekåbe og en del faner, bl. a. fra D. S. K. Også den nye mønt- og medaillesamling vokser støt både ved gaver og ved køb. Undervisningsafdelingen har som gave modtaget adskillige gamle skolebøger, især tyske og danske historiebøger og en række anskuelsesbilleder.

Undervisningsafdelingen er $\mathrm{i}$ øvrigt blevet teknisk udbygget med overhead-projektor og filmfremviser. Isxr det sidste har varet til stor nytte. Afdelingen har indkøbt en del film, bl. a. om 1864, om middelalderborge og om oldtiden. Især filmen om 1864 er blevet flittigt benyttet, især under omflytningen af samlingerne fra de slesvigske krige.

Museumspædagogens arbejde er $i$ øvrigt $i$ stadigt stigende grad blevet en konsulentvirksomhed overfor enkelte lærere, lærergrupper eller hele lærerkollegier.

Fra museet har assistent frk. E. M. Juhler deltaget i DKM's årlige kursus på Try Højskole. Museumspæedagog fru I. Adriansen har deltaget i DKM's årsmøde $\mathrm{i}$ Odense og $\mathrm{i}$ det årlige efterårsmøde på Lakolk. Her var hun desuden koordinator for det forudgående møde for museumsformidling. Inviteret af Nordisk Udstillingsråd har hun deltaget $i$ et seminar i Stockholm og som medlem af $» U d$ valget for lokalhistorie og undervisning $*$ har hun deltaget i 4 udvalgsmøder. J. Slettebo har deltaget i begge nævnte møder i Lakolk, i bestyrelsesmøder i Dansk historisk Fxllesforening og i ICOM's arbejdsudvalg vedr. vedtægtsrevision.

Fru Inge Adriansen har $\mathrm{i}$ det forløbne år publiceret artikler $\mathrm{i} *$ Nordslesvigske Museer« 3 (sm. m. Mette Müller), i »SKALK«, i Sønderjysk Månedsskrift og i Køkkenskolebladet. Sammen med J. Slettebo har hun kommenteret Erik Skrams »Hinsides Grænsen * ved en nyudgivelse af denne bog. J. Slettebo har derudover leveret bidrag til "Sønderjyske historikere efter $1864 \%$ og skrevet forskellige anmeldelser. Han har redigeret Nordslesvigske Museer « 3, og deltaget i redaktionen af „Fra Als og Sundeved» bd. 53 og 54 samt »Fortid og Nutid.«

Lokalerne $i$ slottets nordfløj er også $i$ år blevet flittigt benyttet. Som statsminister Anker Jørgensens officielle gæst besøgte forbundskansler Helmuth Schmidt slottet d. 29. august. Såvel de egentlige droftelser som pressekonferencen og den afsluttende middag var henlagt til slottets nordfløj. Sønderborg Teknikums årsafslutning afholdtes påny i salen, og Sønderborg Musikforening har afholdt 4 koncerter her $\mathrm{i}$ sæsonens lob. Yderligere har der været arrangeret 2 koncerter og en koraften. I foredragssalen har været arrangeret moder af Historisk Samfund for Als og Sundeved, Historisk Samfund for Sønderjylland, Danmarks Naturfredningsforening og Bedre Bymiljø. Sidstnæunte har desuden benyttet lokalerne til en serie studiekredse. Brugen af nordfløjens lokaler er således fortsat stigende. 


\section{Tønder museum}

I efteråret 1975 var som meddelt $i$ forrige beretning her $\mathrm{i}$ årbogen samtlige restaureringsopgaver $i$ Tønder Museum afsluttede, og porthuset var omsider ført tilbage til den form, det havde 1741, ligesom det endelig var lykkedes at gennemføre en rundgang $i$ det samlede museumskompleks. I lobet af sommeren 1976 er pabegyndt en sanering af slotsbanken uden for kunstmuseumsbygningen. Hundrede års hærværk med bebyggelser som gasvark (1864/65), vandværk (1901-02), elværk (1910-11), gasbeholder (1947) og funktionærboliger (1923) vanskeliggør selvfølgelig en blot nogenlunde tilbageføring, men betingelserne er der, og markeringen af slottets beliggenhed $\mathrm{i}$ den skikkelse, det havde førend nedbrydningen omkring 1750, forventes gennemfort i lobet af året. Elværksbygningen er ombygget til brug for kunstmuseet (se dette), gasværket og beholderen er helt fjernet, og den ene funktionærbolig forventes nedrevet $i$ overskuelig fremtid. Så der skulle være en mulighed for, at museets omgivelser bliver lige så perfekte som bygningerne. Hvor lidt sporene i ovrigt skræmmer, ses af, at Tønder kommune ventilerer planer om at placere et nyt rådhus klods op af museets hovedfacade umiddelbart foran den gamle voldlinje. At bygningen formentlig ikke når at blive opført, inden den - som gasbeholderen i sin tid - skal rives ned igen, skyldes nok mindre kommunal visdom end ugunstige tider.

Solidt og systematisk fortsættes der med restaureringsarbejder af museets magasinerede genstande. Overraskende smukke møbler kommer frem af ruinerne stykke efter stykke. Jernsamlingen er nu helt gennemrestaureret, og biblioteket er med assistance af en fagbibliotekar, der har virket som civilværnepligtig, katalogiseret. Fotografisamlingen er betydeligt udvidet, bl. a. med en stor serie optagelser fra Trøjborg.

Sxrudstillinger arrangeres normalt ikke, men en rxkke af seminariets sjældne bøger af topografisk indhold er udstillet. Derimod har museet været behjælpelig ved opsætning af fire udstillinger $\mathrm{i}$ årets løb: Stormflodsudstillingen (i Tønder, Højer august), et forretningsjubilæum i Tønder, hvor vi udstillede ting fra århundredskiftet, en Grænseforeningsudstilling på Nyborg slot (maj) og en kniplingsudstilling i Handelsbankens hus i Tønder.

Museets samlinger er traditionelt udvidet inden for områderne knipling, sølv, fajance og porcelæn. Her er at fremhxve et sølvbæger af Jürgen Hinrichsen, Tønder ( $f r a$ gården Freesmark), en tabatiere af A. C. Böetewadt og en sjzilden spiseske af Peter Petersen, Højer. Topstykket blandt fajancerne er en blå Eckernförde-terrin fra Nibøl-området, og to pompøse porcelænsvaser fra formentlig Berlin er erhvervet fra opr. gården Bjerremark. Med tilskud fra Jorcks fond kunne museet købe en skibskiste fra en af de mest navnkundige hvalfangere $\mathrm{i}$ området, Bandick Frederik Hansen på Hallig Hooge (huset med kongepiselen), 1755. To meget store sandstenssteler (ledstolper) med inscription fra 1762 og fra Ballum-området supplerer fint de to museet i forvejen ejer fra Daler.

Af museets publikationer foreligger en redegørelse for Tønder bys mo- 
numenter (optrykt i museumsårbogen og Sønderjysk Månedsskrift) og en omfattende illustreret museumsvejleder (dansk og tysk udgave).

Besøgstallet (= kunstmuseets) var for kalenderåret 197528.055 (mod 30.960 i 1974). Det strålende sommervejr mærkes altid føleligt på museumsbesøget, hvilket også gxlder for 1976.

S. Sch.

\section{Sonderjyllands kunstmuseum}

Den $i$ forrige årsberetning ( $\AA$ rbog 1975, s. 232) beskrevne ombygning af Tønder bys elværk fra 1910/11 blev for første gang taget $i$ brug ved en stor udstilling af den åbenråske kunstsamler, Carl Gruvemans betydelige og imponerende privatsamling 15. dec. 1976. Rummene viste sig perfekte, og kunstværkerne vakte berettiget opmærksomhed. Til udstillingen var udarbejdet et ret stort gennemillustreret katalog på 60 sider.

Men museets hidtil største udstillingssucces var den første større retrospektive udstilling af den nordfrisiske maler, Carl Ludwig Jessen (18331917), afholdt $i$ maj/juni 1976. Mere end 200 arbejder, med hans navnkundige genrebilleder som Frisisk tingret, Søndagmorgen foran kirken, Sognerådsmøde osv, var stillet til rådighed fra museer og private. Et skrift med professor E. Schlee som hovedforfatter og med henved 250 ill. (132 s.) var udgivet $\mathrm{i}$ forbindelse med udstillingen, $\mathrm{i}$ øvrigt museets største publikation. Besøgstallet var tilsvarende overvældende.

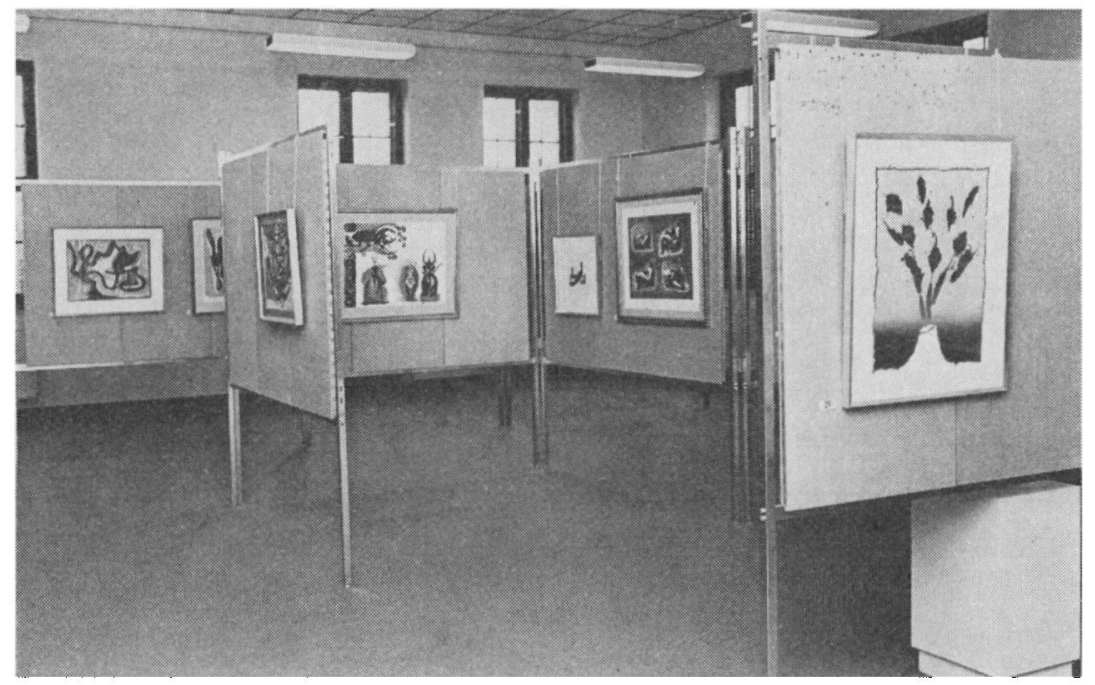

International grafik fra Carl Gruvemans samling, udstillet $i$ annekset til Sonderjyllands Kunstmuseum december/februar 1975/76. (Foto: Tonballe). 
Opmærksomhed vakte også en udstilling af den hidtil upåagtede autodidakt Ejner Richard Jensen, som udstilledes for første gang på museum februar/marts 1976. Og det samme gxlder en smykkeudstilling med arbejder af Anni og Bent Exner (oktober/november 1975).

Fra oktober 1975 stillede man forsøgsvis en af museets trapper til rådighed for amatører, og indtil nu har ni såkaldte wtrappeartister « udstillet. Kvaliteten er begribeligvis flakkende, men som forseg på at overvinde den forfærdende kløft, der er mellem såkaldt etableret kunst og den folkelige ende, er ideen nok rigtig.

Et paradenummer som GRØNNINGEN, hvis beskedneste halvdel udstilledes her februar/marts 1976, var ingen publikumssucces, hvis skylden så er. Vi var vel nogle stykker, der glædede os over en veloplagt Richard Mortensen. Hans »Glade over sejren i Østen « (30. april 1975) gjorde sig godt $\mathrm{i}$ den tidligere kulturfjerne turbinehal på Slotsbanken, men noget tillobsstykke blev det ikke.

Museets faste samling er forøget med ca. 50 arbejder, og man har $i$ lighed med foregående år arrangeret mindre udstillinger $i$ en række af landsdelens andre byer.

Den i perioden vedtagne nye museumslov (gyldig fra 1. oktober 1976) er ingen gevinst for Sønderjyllands Kunstmuseum.

S. Sch.

\section{Kunstmuseet Holmen, Løgumkloster}

I det forløbne år er 100-års dagen for Olivia Holm-Møllers fødsel passeret, og man har for at hædre hende og hendes kunst udgivet et lille hefte, hvori der $i$ korte trak er fortalt om hendes liv og arbejde.

Der har i årets løb været afholdt 2 mindre særudstillinger. I sidste halvdel af august måned viste Johny Haugaard, København oliebilleder og akvareller, og $i$ sidste del af oktober var det 2 unge Ribe-malere, Karsten Ramsing og Erling Leick, der $\mathrm{i}$ de små stuer udstillede deres oliemalerier. Desuden var den store sal i januar og halvdelen af februar ramme om udstillingen Skolen for livet*, arrangeret af Nationalmuseet - en opgave, der for så vidt falder udenfor et kunstmuseums virkefelt, men da Holmen kun har pligt til at udstille Olivia Holm-Mollers arbejder de 9 af årets måneder, blev bygningen $i$ år udnyttet til denne udstilling, der havde interesse for en kreds af mennesker udover de kunstinteresserede.

Udlånsvirksomheden har som sædvanligt været 10 malerier til Grenå kommune, Olivia Holm-Møllers fødeegn, 4 stk. til Løgumkloster Rådhus og 5 til Løgumkloster Højskole. I ca. 1 måned har Kunstforeningen, Gl. Strand 48, København haft lånt 2 malerier til udstillingsrækken "Dansk Kunst - en udstillingsrakke opdelt i 30 års perioder, hvor Olivia HolmMøller var repræsenteret både i perioden 1885-1915 og 1915-45.

Holmen har nu bestået i 5 år, og skal der gøres status, må konklusionen 
blive, at der er et trofast, men desværre lille publikum, der med glæde besøger et kunstmuseum. Erfaringer fra andre steder her $\mathrm{i}$ landet viser det samme, og alle håber vel som vi, at interessen for billedkunst må vokse og blive en ligeså stor selvfølgelighed som det at høre god musik.

$$
\text { E. } K \text {. }
$$

\section{Samlingen af arbejdsredskaber og bondemobler pá Jacob Michelsens gård I Kolstrup}

På årsmodet for styrelsen, der blev afholdt d. 9.10.75, aflagde formanden beretning for året, der var gået. Heraf fremgik, at både interessen udefra og den interne aktivitet havde holdt sig uforandret. En udstilling med brygning af gammeltol som emne blev en succes, bl. a. takket være skoleinspektør S. Elkxr Petersen, Smidstrup, der fremviste en film om brygning af gammeltal i Østjylland, begge dage med fuldt hus ved 6 fremforinger. Som en kuriositet konstateredes en brugsforskel i form af trægærkrans contra mursten.

Den lovede beskrivelse af gårdens historie, velvilligst forfattet af redaktor M. Kamphövener, udkom i Sønderjysk Månedsskrift for september, og foreligger $i$ særtryk.

Fru Rossen, Maskovgård havde skænket tekstiler og hovedtøj, frk. M. Skov, Abenrå: 1 silkekjole (1890) og frk. Thaysen, Tumbøl: 2 hjemmevævede forklæder.

Som udstilling i 1976 godkendtes emnet: »Bondekonens urtehave« i tilslutning til Danske museers oplysningskampagne om ressourceanvendelse.

Regnskabet for institutionen blev $i$ revideret stand aflagt af bankdirektør B. Nielsen. Det udviste en balance på omtr. $2000 \mathrm{kr}$. og godkendtes.

Til styrelsen genvalgtes fhv, amtskontorchef J. Caspersen og fysioterapeut, frk. A. $H$. Michelsen, til revisor statsaut. revisor $O$. Thaysen.

\section{Hlstorisk forenIng for Grásten by og egn}

Foreningen blev stiftet i februar 1975, og at foreningen opfyldte et behov, kan ses deraf, at der ved generalforsamlingen i april 1976 var tilmeldt 104 medlemmer.

Man har $\mathrm{i}$ foreningens første år lagt grunden til et lokalhistorisk arkiv, til hvilket der allerede er indgået en del materiale såsom billeder, foreningsprotokoller og ejendoms- og personlige papirer. Det indsamlede materiale spæender over et tidsrum på ca. 200 år.

Foreningen lånte i november SLA.s vandreudstilling: Hvad er et lokalhistorisk arkiv? Udstillingen var arrangeret i Sydbank i Gråsten, og den blev set af mange mennesker. I forbindelse med udstillingen holdtes møde i Rinkenæshus, hvor socialinspektør Olav Christensen, Haderslev talte om 
lokalhistoriske arkiver, og der blev vist en del af det indsamlede billedmateriale.

Til jul udsendte foreningen et lille årsskrift, der fortalte om en del af egnens mindesten. Tillige bragtes der artikler om Kværs kirke-inventarium, en overladelseskontrakt, samt en kontrakt mellem smed og bønder i Rinkenæes fra 1827.

Ved generalforsamlingen $i$ april talte museumsleder Holger Jacobsen, Ảbenrå, morsomt og interessant om Ảbenrå skibsfart.

P. A.

\section{Den store egnsvandring 1975}

Ar efter år melder en fast gruppe af Historisk Samfunds medlemmer sig til den store egnsvandring, og det gælder derfor om at variere målene mest muligt.

I 1974 gik turen mod nord, først til Rosenholm, hvor vi blev modtaget med stor gæestfrihed og derefter til Jelling, hvor museumsinspektør Thorkild

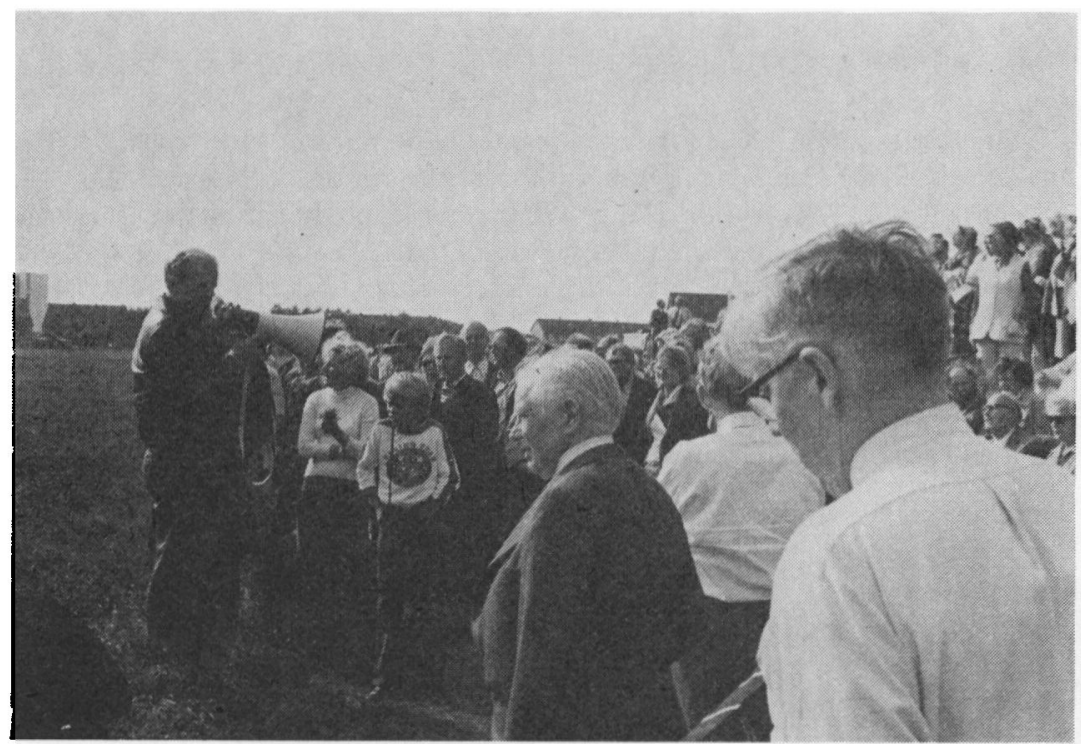

Tinnumborg ligger lige uden for Vesterland syd for vejen til Kejtum. Busserne kunne ikke køre belt ud til det store ringvoldsanlag. Man fik da lejlighed til at sidde $p 2$ en solbeskinnet skråning med god udsigt til de fjerne volde og glede sig over det milde efterårsvejr, mens man lyttede til Ole Harcks foredrag om det gamle borganlag. (Foto: Inger Bjørn Svensson). 


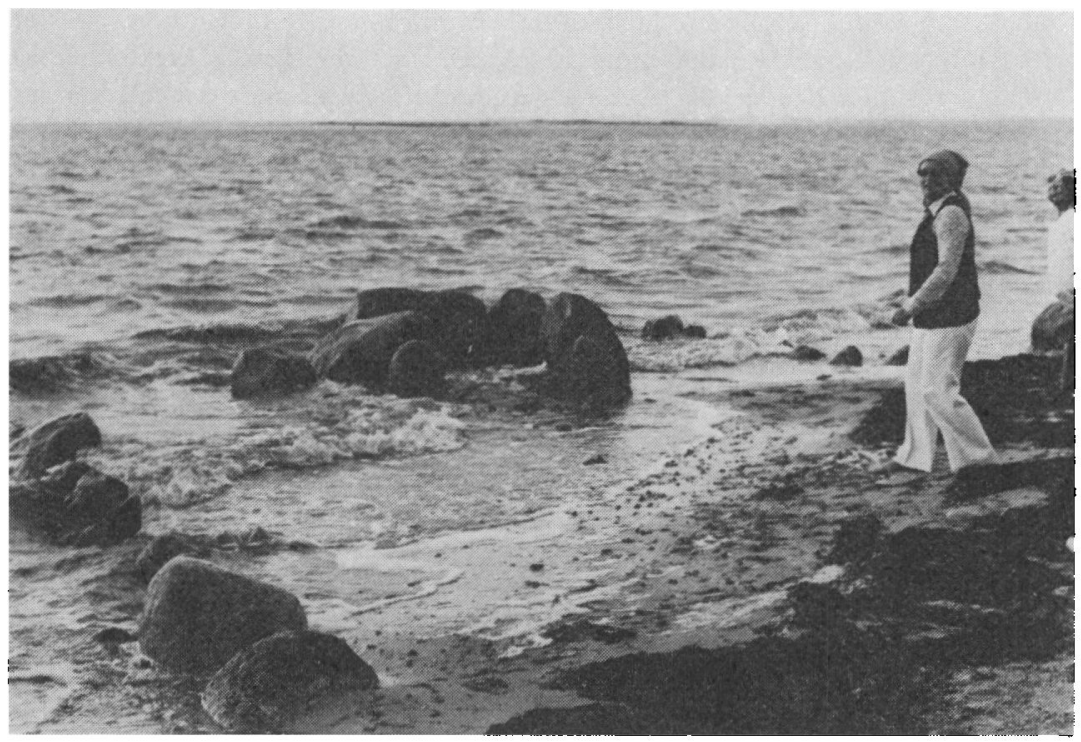

En jettestue $i$ strandkanten ved Arksum vidner om den landsankning, der er sket. (Foto: Inger Bjørn Svensson).

Ramskous foredrag blev et af turens højdepunkter. I 1975 skulle vi sydpå, og man vedtog, at turens deltagere skulle "vandre til Sild. Man vedtog også, at der højst kunne deltage 250 personer, og som sxdvanlig meldte der sig så mange, at der blev sat en ekstra bus ind. Alligevel måtte vi med bedrøvelse sende afbud til 44. Endnu engang måtte vi diskutere, om vi burde gentage udflugten, så vi fik to ture med færre deltagere pr. gang. Vi blev 287 i 1975, og det er faktisk for mange.

Egnsvandringsbusserne mødtes klokken ni i Havneby, og på turen over til List drak man morgenkaffe.

I St. Niels, den gamle landsbykirke i Vesterland, fortalte pastor H. F. Petersen lidt om kirkens historie.

Stormfloden 1436 ødelagde landsbyen Eidum, der lå, hvor nu Vesterlands vestgræense er. Beboerne flyttede mod øst - det var anden gang, de måtte flytte deres by -, men kirken, der lå ost for det gamle bosted, blev skånet og brugt til gudstjenester i 200 år - indtil den store stormflod i 1634. Da var kirken ved at sande til, og man solgte $i$ hast blytaget; for de indkomne penge opførte man St. Niels, som blev en ret lille kirke, (der dog senere er udvidet betydeligt), og da man havde solgt blyet, nøjedes man med rørtækning. 
Den trefløjede, sengotiske altertavle fra midten af 1400-tallet og det lille triumfkors over korbuen tog man med fra den gamle kirke. Døbefonten derimod befinder sig idag $i$ en anden af Vesterlands kirker, nemlig St. Nicolai. Det øvrige inventar i St. Niels er nyere. Der holdes ikke mere almindelige gudstjenester i St. Niels, men den danske menighed i Vesterland bruger kirken ved bryllupper, konfirmationer og begravelser samt ved julegudstjenester.

Pastor H. F. Petersen fortalte derefter lidt om St. Severin kirke i Kejtum - den er fra midten af 1100-tallet, og senere på dagen fik vi lejlighed til at kigge ind i denne kirke.

Sluttelig fik vi en kort orientering om det danske arbejde $i$ Vesterland. Efter en lille fodtur rundt $\mathrm{i}$ og om kirken, hvor særlig de romanske sokkelkvadre $\mathrm{i}$ kirkens nordlige fundament fangede opmærksomheden - man mener, de er taget fra den gamle Eidum kirke - kørte busserne til Hans Meng-skolen, hvor der var dxkket op til den medbragte madpakke. Da frokostøllet var gratis (= inkluderet $i$ turprisen) blev det et billigt måltid.

$\mathrm{Da}$ alle var mætte, rykkede man sammen i gymnastiksalen; der var absolut ikke god plads, og det har turudvalget ansvaret for; det var de sidste 38 tilmeldte, der kunne mærkes her, men det lykkedes nogenlunde at få placeret alle. For øvrigt glemte man pladsproblemerne under universitetslektor Ole Harcks lysbilledforedrag om hans udgravninger ved Arksum. Foredraget er gengivet i Sønderjysk Månedsskrift oktober /november 1975.

Efter et lidt blesende "frikvarter" i Vesterland, gik turen mod Kejtum. Undervejs blev der et kort ophold ved Tinnumborg, et anlæg, der ligner Fyrkat og Trelleborg. I dag er der dog ikke andet at se af Tinnumborg end resterne af de sammensunkne volde. Ole Harck fortalte, og vi nød belæringen og det milde solskin på en skråning, hvor der var rigelig plads til os alle.

Kejtum er en idyl med gamle huse og snævre gader. Busserne snoede sig med besvær rundt $\mathrm{i}$ idyllen, og det kneb lidt at holde styr på, hvornår hvem var hvor, og om alle havde varet alle steder. I Kejtum skulle man ikke blot se St. Severin kirken, men også det kønne, gamle frisiske hus, hvis historie man efter ønske kunne få serveret på dansk, tysk eller frisisk, man kunne se museet, og endelig havde Ole Harck taget ophold på diget ved Arksum. Busserne gjorde holdt kortere eller længere fra Ole Harck, og nu kom hans tilhørere for alvor ud at vandre. Det gik langs stranden, over stenter og mellem flygtende får, op og ned ad digeskrænterne i vindstyrke mindst ni - en blæst, der fik kjolebærende deltagere til at ønske, at de havde iført sig slacks om morgenen.

Det blev en frisk afslutning på selve egnsvandringen - tilbage var blot middagen på færgen hjem, den var god, men noget sparsomt tilmålt, og sluttelig fandt vi $i$ busserne de nye sangbøger frem og sang os frem mod hjembyen.

\section{I.B.S.}




\section{Vedrerende stof tII wNoter og nytu}

Redaktionen af Sønderjyske Årbøger modtager meget gerne korte beretninger fra lokalhistoriske foreninger, arkiver, samlinger og arbejdskredse.

Der er så megen grøde $i$ dette arbejde i både Nord- og Sydslesvig, at man af tidsmæssige grunde og for ikke at fornærme nogen må anmode om, at manuskripter indsendes uopfordret inden 1. april hvert år.

\section{Amtskredsenes arbejde}

\section{Hadersilev amtskreds}

Den 10. august 1975 holdt amtskredsen byvandring i Haderslev under ledelse af seminarielektor Hans V. Gregersen og socialinspektør Olav Christensen. Det var usædvanligt hedt. Men i domkirken var der køligt. H. V. Gregersen fortalte om kirkens bygningshistorie og den samtidige udvikling $i$ sprog og historie. Under kaffebordet $i$ den gamle latinskole fortsattes med fortælling om reformationstiden og skolens historie.

Her taltes 22 deltagere. Med Olav Christensen som leder vovede selskabet sig ud. I de gamle smalle gader gav husene skygge. De to ledere gav en fortrinlig beskrivelse af Haderslevs aldre og nyere udvikling. Den illustreredes af de mange gamle huse og beliggenheden af de forsvundne slotte. Byen gør her en indsats for at restaurere og bevare det gamle. Da der blev takket af ved Klosteret, virkede deltagerne endnu veloplagte efter at have holdt ud i 41/2 time.

Generalforsamling og møde afholdtes den 5. april i Rødding. Genvalgt til styrelsen blev Hilmar Madsen og Kresten Hansen. Under eventuelt gav landsarkivar P. K. Iversen en oversigt over de bøger, der står foran udgivelse fra Historisk Samfund.

Under det efterfølgende møde holdt museumsinspektør Hans Stiesdal foredrag og viste lysbilleder om middelalderlige og tidligere befæestningsanlæg i Danmark og navnlig i Sønderjylland. Emnet var noget specielt, men for den interesserede meget udbytterigt. Inden mødet sluttede, besvarede Stiesdal nogle spørgsmål og uddybede noget af det tidligere sagte. Der var 54 deltagere.

$$
\text { K. } H \text {. }
$$

\section{Abenrá amtskreds}

Den 4. august 1975 holdtes den historiske søndag. Der var 6 besøgssteder på dagsordenen:

1. Besigtigelse af en afdxkning af en gammel brolægning ved Rønsdam ved Bov. Fhv, overlærer R. P. Sørensen og den unge gårdejer, på hvis mark afdxkningen havde fundet sted, var begge tilstede og fortalte levende og interessant om den gamle vej og dens omgivelser. 
2. Gården Vold ved Varnæs. Man samledes i den dejlige park - lignende have, hvor larer Ib Andersen, Varnxs fortalte om Vold og sagnet om junker Vigge. De fremmødte nød foredraget $i$ den pragtfulde have $i$ det smukke vejr.

3. Abenrå Museum, der var taget med for det tilfxlde, at det skulle regne. Heldigvis udeblev regnen, og fru Callesen havde let ved at klare besøget.

4. Den nyrestaurerede Bjolderup kirke, der blev fremvist af et kyndigt medlem af menighedsrådet.

5. Hellevad kirke, som fremvistes af sognepræst G. Peters-Lehm. Man fik lejlighed til at høre det nye orgel og hørte foruden om kirken også om begravelsesskikke og traditioner.

6. Hærulfstenen ved Oksevejen, som gårdejer Senius Tiedemann fortalte om.

Den 19. 11. 1975 holdt Bovrup Borgerforening sammen med amtskredsen en hjemstavnsaften på ungdomsskolen. Lxrer Ib Andersen fortalte om diakonerne fra Bovrup, og pastor Urban Schrøder viste lysbilleder både fra det gamle og det nye Bovrup. En af ham forfattet Bovrupsang blev sunget. Der var hundrede deltagere.

Den 11. 3. 1976 holdtes en hjemstavnsaften i Varnæs skole, hvor formanden for amtskredsen, Holger Jacobsen, fortalte om Jomfru Fanny. Urban Schrøder fortalte om, "hvad præstens møddinghul gemte«, på baggrund af udgravninger han havde foretaget sammen med Ib Andersen. Der var herved fremkommet adskillige bortkastede ting, der kunne fortælle om fortiden. Efter kaffebordet viste Ib Andersen lysbilleder fra Varnæs. Der var atter over hundrede deltagere.

Amtskredsens formand har talt om Ảbenrå søfart eller andre emner ved velbesøgte møder i Holbøl landbohjem, Jejsing centralskole, Tønder omsorgsklub, Bevtoft forsamlingshus, Gråsten landbrugsskole og Frimurerlogen i Åbenrå. Alle disse steder er der blevet oplyst om Historisk Samfund for Sønderjylland.

Ved generalforsamlingen den 28. 4. 1976 på Det sønderjyske Landsarkiv genvalgtes pastor Urban Schrøder til bestyrelsen, hvorimod formanden, trods stærk opfordring fra forsamlingen om at fortsætte, onskede at trække sig tilbage. Han blev valgt til xresmedlem af amtskredsen, og landsarkivar Iversen takkede for den mangeårige indsats for Historisk Samfund. Som ny formand valgtes forsikringsdirektor Poul Andersen, Munkeladen, Rinkenæs. Efter generalforsamlingen fortalte politiassistent Knud Jensen, Padborg om "Heksetro og brødbagning " og illustrerede sit interessante foredrag med gode lysbilleder.

H. J.

\section{Sonderborg amtskreds}

Onsdag d. 3. 12. 1975 afholdtes møde $i$ Tandslet forsamlingshus. Museumsinspektør J. Slettebo, Sønderborg, viste lysbilleder og fortalte om sønder- 
jyske gårde, møbler og brugsgenstande på vore oldeforældres tid. Der var livlig spørgelyst blandt de ca. 120 deltagere i mødet. I salen var der arrangeret en udstilling af antikviteter, både møbler, porcelæn, glas og service.

I februar 1976 henvendte vi os til Nationalmuseet angående en fornyet udgravning i Nydam mose, idet vi især gjorde gældende, at en fortsat udtorring af mosen kunne være en fare for de endnu ikke udgravede oldtidsminder. 24. 3. fik vi svar tilbage fra overinspektør, dr. phil. Mogens Ørsnes, der gav tilsagn om, at Nationalmuseet til sommer kommer herned for at se på lokaliteterne og foretage prøveboringer for at kunne vurdere, om der er sket en sådan ændring i grundvandsstanden, at der er fare for, at de oldsagsførende lag ikke længere vil kunne bevare evt. oldsager for fremtiden. Hvis dette er tilf $x$ ldet, vil Nationalmuseet prioritere en fornyet udgravning meget højt.

Onsdag d. 7. 4. 76 afholdtes møde $\mathrm{i}$ foredragssalen på Sønderborg slot. Inspektør ved Nationalmuseet, Hans Stiesdal, holdt foredrag med lysbilleder over emnet: Urmagerkunstens udvikling med særligt henblik på tårnure og andre monumentalure. Et interessant og fængslende foredrag, der affødte mange spørgsmål fra de 40 fremmødte.

J.D.

\section{Tender amtskreds}

Arbejdet i Historisk Samfund, Tønder amtskreds, har i afvigte år haft et roligt og stille forløb, og der har ikke varet sammenkomster ud over dem, der efterhånden er skabt tradition for.

Egnsvandringen, med et forøvrigt stadigt vigende deltagertal, var henlagt til Agerskovegnen under sparekassedirektor H. P. Jensens ledelse. Der var bl. a. besøg på Nørrevold $i$ engen ved Fiskbæk, og man kørte over Roost til Agerskov kro, hvor der blev drukket kaffe, og hvor H. P. Jensen fortalte morsomme træk om »originaler«, der havde levet på egnen. Turen havde 25 deltagere.

I januar måned 1976 var arrangeret et møde på Tønder museum med museumsdirektør, dr. phil. S. Schoubye som rundviser. Det blev et interessant møde med egnens museum og en engageret museumsmand. Ved det efterfølgende kaffebord på Tønderhus var der livlig snak om spredte emner mellem de 20 deltagere.

Årsmødet og generalforsamlingen var tilrettelagt $\mathrm{i}$ forbindelse med museumsinspektør $\mathrm{H}$. Stiesdals møderakke $\mathrm{i}$ kredsene og afholdtes tirsdag d. 6. april på Tønderhus. Sekretæren S. N. Christensen, Ravsted, udtalte mindeord over amtskredsens afdøde formand, fhv. gårdejer Søren Nissen, Harres. Beretning og regnskab godkendtes. Nyvalgt til bestyrelsen blev fhv. sognerådsformand Knud Nielsen, Visby, og genvalgt S. N. Christensen, Ravsted. Der blev under eventuelt givet tilslutning til bestyrelsens forslag om en byvandring i Flensborg i midten af juni måned. Efter generalforsamlingen fulgte et interessant og charmerende fremført foredrag med lysbille- 
der: »Sønderjyske borge og voldsteder $i$ ny belysning a af museumsinspektør H. Stiesdal. Der var 100 deltagere.

Omtales skal også den aktivitet, der udfolder sig i de lokalhistoriske foreninger. I Tinglevområdet har der $\mathrm{i}$ sognene været en vandreudstilling, hvor lokale kræfter medvirkede. I Bredebro- og Skxrbxk kredsen er der i vinterens lab afholdt flere arrangementer med lokalhistoriske emner. I Brøns- og Løgumkloster kredsen har der været enkelte møder.

Vi kan således glæde os over en vældig interesse og aktivitet indenfor det historiske arbejde $\mathrm{i}$ det gamle Tønder amt.

S.N.C.

\section{Sydslesvig amiskreds}

Søndag den 17. august 1975 blev den traditionelle sommerudflugt gennemført under stor deltagelse af både unge og gamle. Efter kaffebordet på Amtmandsgården $\mathrm{i}$ Rensborg talte dr. Ole Harck om kanalbyggeri i Slesvig og Holsten. Dermed var der givet en bred baggrund for selve dagens emne og udflugtsmål, nemlig »Den gamle Ejderkanal«. Ude i marken så vi resterne af kanalen ved Kluvensiek, hvor bl. a. de vældige jernstativer vidner om fortidens aktiviteter. Disse er et produkt af Carlshütte fra Bydelsdorf. Turen gik videre over Sehested-færgen til Gettorp og sluttede ved slusen ved godset Rathmannsdorf, hvor endnu en sluse på $35 \mathrm{~m}$ samt et idyllisk stykke Ejderkanal kan beses. Dr. Ole Harck er ikke kun en god taler at lytte til, men også en fortræffelig fortæller ude i marken.

Tirsdag den 21. oktober 1975 blev det traditionelle efterårsmode afholdt i Lolfod 69 i Slesvig. Konsulent Age Lauridsen talte om emnet *Har vikingerne bygget en skibskanal mellem Sli og Trene? «. Foredraget byggede på Lauridsens tidligere offentliggjorte teorier og gav anledning til en interessant og dybtgående drøftelse, hvorunder Åge Lauridsen understregede, at kun gravninger kan afslore, om der er tale om en virkelighed eller tankekonstruktion bag hans hypotese. Mødet, der havde samlet mange tilhørere fra hele landsdelen, blev holdt i samarbejde med Folkeuniversitetet. Ved mødets slutning blev der gjort rede for de nyeste udgravninger i og omkring Slesvig by.

Torsdag den 8. april 1976 afholdt Sydslesvig Amtskreds sin generalforsamling på Dansk Centralbibliotek i Flensborg. Overbibliotekar Hamre var modeleder. Formanden Lars H. Schubert aflagde beretning og forstander Anna Schrøder aflagde kasseberetningen. Efter en kort diskussion blev begge beretninger godkendt. Til valg stod Anna Schrøder og pastor Flemming Møller. Begge blev genvalgt.

Efter kaffebordet talte inspektør fra Nationalmuseet Hans Stiesdal om » Sønderjyske borge og voldsteder i ny belysning «. Foredraget, der blev ledsaget med lysbilleder, påhørtes med stor interesse af den talstærke forsamling. Det blev i alle måder en vellykket aften.

Tirsdag d. 1. juni holdtes der med 50 deltagere under ledelse af journalist 
Alex Herz aftenvandring i Slesvig gennem resterne af den gamle barokhave ved Gottorp Slot. På slottet modtog værkstedsleder Wimmel deltagerne og gav et interessant indblik $\mathrm{i}$ tingene bag kulisserne, $\mathrm{i}$ værksteder og konserveringsrum.

Aftenen sluttede med kaffebord på den gamle stampemølle - det nuværende *Waldhotel $*$.

L.H.S. 


\section{Årsberetning og regnskab 1974-75 \\ Ved Peter Kr. Iversen og $H$. Lildholdt}

Historisk Samfund for Sønderjylland holdt årsmøde søndag d. 9. maj 1976 på Forsamlingsgården Frej i Christiansfeld. Mødet begyndte kl. 14, og der var mødt godt 100 medlemmer.

Formanden, landsarkivar Peter $\mathrm{Kr}$. Iversen bød velkommen, især til de to tilstedevarende xresmedlemmer, redaktør Morten Kamphövener og museumsinspektør $H$. Neumann. Til ordstyrer valgtes formanden for Haderslev amtskreds, fhv. gårdejer Kresten Hansen, som konstaterede, at forsamlingen var lovligt indvarslet, og gav ordet til formanden, som indledede med at mindes gårdejer Søren Nissen, Harres, der i flere år dygtigt havde ledet Tønder amtskreds, og som på flere områder havde været foregangsmand inden for det lokalhistoriske arbejde. Derpå aflagde formanden følgende beretning:

Når man $\mathrm{i}$ mange år enten på den ene eller anden måde har været med til at udarbejde årsberetningen, kan det vel ikke undre, at den efterhånden kan få et lidt stereotypt præg. Det er jo i det store og hele de samme opgaver og handelser, der skal berettes om med større eller mindre variationer, alt afhængig af hvilke sider af virksomheden der er blevet lagt mest vægt på vedkommende beretningsår. Vi har sædvanligvis indledt med at gøre status over medlemstallet og har set det vokse og dale, men generelt har der dog været stigende tendens. $\mathrm{Da}$ medlemstallet for nogle år siden voksede meget kraftigt - der var $i$ lobet af et år en stigning på næsten tusind - var vi klar over, at det ville knibe at holde fast på alle disse nye medlemmer. Der var derfor $i$ de følgende år en afgang, omend mindre end forudset, og nu ser det ud til, at den nedadgående linie i medlemstallet er standset. Det er nu stabiliseret på 2611, og vi kan notere en mindre fremgang i sammenligning med sidste år. Vi venter endvidere, at den hverveindsats, der på forskellig måde vil blive iværksat $i$ sommer og efterår sammen med udsendelse af flere nye og gode bøger på ny vil få flere til at slutte op om foreningen. 
I hvert fald er der ikke tale om dalende historisk interesse $i$ landsdelen, idet der rundt omkring $\mathrm{i}$ kommunerne oprettes historiske foreninger. Det er en glædelig udvikling, hvorved mange flere er blevet engageret $i$ historisk arbejde på den ene eller anden måde, og det vil ganske givet også på langere sigt betyde, at der her skabes en baggrund for tilgang af nye medlemmer til vor forening.

Forinden jeg beretter om foreningens enkelte aktiviteter, skal jeg oplyse, at styrelsen på grund af de stigende trykkepriser har set sig nødsaget til at forhøje medlemskontingentet med fem kroner, således at det nu er oppe på $35 \mathrm{kr}$. + porto m. v. Men i betragtning af de modydelser, der præsteres for kontingentet, kan dette vel stadig karakteriseres som moderat i sammenligning med, hvad medlemmerne $\mathrm{i}$ andre historiske foreninger må betale.

Som medlemmerne vil have bemærket, udsendtes Sønderjyske Arbøger sidste år tidligere end de foregående år $-i$ november - mod de senere år lige ind under jul. Det er planen, at udsendelsen i år skal ske endnu før. De to hovedbidrag i den 246 sider store årbog 1975 var N. H. Jacobsens afhandling: Debatten om de nordslesvigske baners udvikling før 1864, der efterfølges $\mathrm{i}$ år af en afhandling om udviklingen efter 1864, og Jørgen Wittes afhandling om Den slesvigske Forening 1849-52. Herudover var der mindre, men ikke mindre laseværdige bidrag af $\mathrm{H}$. V. Gregersen, Holger Jacobsen og Finn Friis. Endvidere skal nævnes Troels Finks store og grundige anmeldelse af $\mathrm{H}$. V. Gregersens disputats. Redaktionen beklager, at anmeldelsesstoffet sommetider er noget ujævnt, idet anmeldelser, der er lovet, udebliver trods løfter og mange rykkere. Man har også taget spørgsmålet om oversigter over tidsskriftafhandlinger vedrørende sønderjysk historie op til fornyet overvejelse, uden at det dog er kommet til endelig klaring på dette punkt. Rubrikken Noter og Nyt udvides stadig med beretninger fra nye institutioner og giver værdifulde bidrag til belysning af nye initiativer på det lokalhistoriske plan.

Et register over indholdet af Sønderjyske Arbøger fra 1940 til i dag er under udarbejdelse af overbibliotekar N. Kragh Nielsen, Rødding.

Sønderjysk Månedsskrift blev igen i 1975 en diger årgang på i alt 496 sider. Foruden boganmeldelser, oversigter over avisartikler, grænselandsdagbogen og nogle småstykker bragtes ca. 70 artikler, som spæender over et vidt spektrum - i tid, sted og emner. Der har i de senere år været en jævn tilgang af abonnenter til Sønderjysk Månedsskrift, der er landets største lokalhistoriske tidsskrift og enestående i sin art. I beretningsåret har til- og afgang så nogenlunde ophævet hinanden, dog således at abonnenternes tal er øget med to, hvorefter dette er 1524. Det er glædeligt, at det har været muligt $i$ en økonomisk depressionsperiode at holde fast på abonnenterne. De stigende produktionsomkostninger og portoforhøjelsen har medført, at abonnementsprisen har måttet forhøjes til $52 \mathrm{kr}$. årligt, men når forhøjelsen ikke er blevet større, skyldes det bl. a. den sarlige ordning med det sønderjyske museumsråd, hvorefter Sønderjysk Månedsskrift får museums- 
årbogen med dens mange gode og interessante artikler stillet til rådighed som et særhxfte, og at Sønderjysk Skoleforening betaler abonnementet for 100 sydslesvigere. Endvidere har Sønderjysk Månedsskrift modtaget støtte fra Dansk Kultursamfund og fra Sønderjysk Lånekasse.

Det af mange med længsel ventede register over indholdet af Sønderjysk Månedsskrift fra 1945-74, som er udarbejdet af overbibliotekar Niels Kragh Nielsen, Rødding, foreligger nu i korrektur og kan forventes klar til udsendelse om et par måneder. Det bliver større end forudset, og prisen må nok fastsæettes til ca. $15 \mathrm{kr}$., måske $20 \mathrm{kr}$.

Med hensyn til virksomheden inden for serien: Skrifter, udgivne af Historisk Samfund for Sønderjylland kan oplyses, at Sønderjyske Historikere, nr. $44 \mathrm{i}$ rækken, nu ved påsketid har kunnet udsendes til subskribenterne. Aksel Lassens store værk om valg mellem dansk og tysk, der vil få et omfang på ca. 525 sider, og som er lovet støtte fra Carlsberg-Fondet og Dansk Kultursamfund, foreligger i første korrektur og kan forventes udsendt hen på efteråret. Cand. mag. Lars Henningsen bistår redaktionen som redaktionssekretær ved dette værk. Til udgivelsen af oyerarkivar Aage Rasch's ufuldendte manuskript om den slesvig-holstenske kanal er modtaget tilsagn om støtte fra det humanistiske forskningsråd, og der er foreløbig modtaget tilsagn om støtte på $30.000 \mathrm{kr}$. fra Rislum-Fonden til udgivelse af Thade Petersens store Rømø-historie. For at denne udgivelse kan virkeliggøres, mangler vi dog endnu $20.000 \mathrm{kr}$., som der er indsendt ansøgning om. Forhåbentlig vil denne bog kunne sættes $\mathrm{i}$ arbejde $\mathrm{i}$ løbet af efteråret, når økonomien er sikret. Arbejdet med renskrivningen af fhv. stadsskoleinspektør L. S. Ravns store biografiske værk om nordslesvigske skolelærere $i$ 1800-tallet skrider langsomt, men støt fremad. Foreløbig er der renskrevet 140 sider, men hele varket vil med registre komme til at fylde ca. 600 maskinskrevne sider i A-4 format. Fru Tonny Hermansen har den sidste måned hjulpet med den meget krævende maskinskrivning. Der vil nok gå godt et års tid, inden varket er klar til udgivelse.

Inden for serien Sønderjyske Levnedsløb udsendtes i juli 1975 lektor Peter Becks erindringsbog: Ung mand fra Sundeved, en fortsættelse af hans: Dansk dreng i Sundeved. Begge er solgt godt og giver et beskedent overskud, som kan anvendes til udgivelse af andre bøger inden for serien. Under forberedelse er her afdøde mangeårige medlem af Sprogforeningens ledelse Hans Jørgensen Hansen af Lysabildskov's erindringer, til hvis udgivelse vi har modtaget støtte fra Fabrikant Mads Clausens Fond. Endvidere vil en af de nærmeste dage manuskriptet til fhv. forstelærer J. $\mathrm{H}$. Jensens erindringer fra mere end 50 års virke i Felsted sogn kunne sendes til opsetning. Til denne sidste bog er der modtaget stotte fra Lundtoft kommunalbestyrelse og Sønderjyllands amtskommunes undervisnings- og kulturudvalg. Vi håber, at disse bøger kan udsendes $\mathrm{i}$ løbet af næste vinter, om muligt helst før jul. Vi har flere gode erindringsmanuskripter liggende og har også indsendt ansøgninger om støtte til deres udgivelse.

Vi har et smertensbarn, nemlig billedverket, hvor det har sine vanske- 
ligheder med at få bind II, der skal omfatte tiden 1864-1920, og bind IV, der skal behandle Sydslesvig efter 1920, klar til udgivelse. Vi luftede ved sidste årsmøde det håb, at professor Troels Fink nu havde tid til at tage sig af bind IV, men han har måttet vikariere i sin gamle stilling som generalkonsul og har været optaget af andre gøremål. Vi har derefter forsøgt at få bind II klargjort først, og det ser măske ud til, at det kan lykkes, efter at museumsdirektør Jørgen Paulsen nu har taget sin afsked. Som det fremgår af regnskabet henstår næsten $150.000 \mathrm{kr}$. til den fortsatte udgivelse af billedværket, men tilskrivningen af renter modsvarer næppe stigningen i produktionsomkostninger. Det ville være meget ønskeligt, om udgivelsen af disse to bind kunne fremmes.

Redaktionen har ikke $i$ de senere år haft en fast redaktionssekretær, men har arrangeret sig fra bog til bog. Dorrit Andersen har haft sekretærarbejdet ved Sønderjyske Historikere, medens overbibliotekar Gustav Auring tilrettelxgger udgivelsen inden for Sønderjyske Levnedsløb. Lars Henningsen tager sig som nævnt af Aksel Lassens store værk.

I denne forbindelse kan nævnes, at Lars Henningsen, der sidste sommer afsluttede sit studium, med dronning Ingrids tilladelse har fået tildelt det beløb, som Historisk Samfund for nogle år siden modtog fra Ingrid-Fondet for Sønderjylland. Beløbet, der oprindeligt var på $25.000 \mathrm{kr}$., men som med renter voksede til ca. 35.000 kroner, var tæenkt som belønninger ved en prisopgave om Gråsten. Imidlertid kom der kun én utilfredsstillende besvarelse, og pengene anvendes derefter af Lars Henningsen til studier over sønderjysk fattigvæsens historie i første halvdel af 1800-årene. Som det fremgår af regnskabet, er foreløbig kun en del af pengene brugt.

Historiske Samlinger har igen i år modtaget værdifulde gaver i form af billeder. Den største er afd. fotograf Th. Christesens efterladte samlinger af soldaterbilleder m. v., i alt 9 store kasser, som kommandantskabet på Søgård har afleveret. Disse billeder og negativer er ikke talt op, men derudover er billedsamlingen foroget med knap 3000 stk., hvoraf ca. 300 er købt eller fremstillet på landsarkivets fotografiske atelier. Registreringen og ordningen af billedsamlingen er fortsat af fruerne Vibeke Gribsvad og Xenia Schaumburg. Til indkob af historiske film har Historiske Samlinger fra Lauritz og Augusta Dahls Mindelegat modtaget $5000 \mathrm{kr}$., og endvidere har Historiske Samlinger som sxdvanligt modtaget $15.000 \mathrm{kr}$. fra Dansk Kultursamfund. Fotograferingen af gamle huse og gårde $i$ det tidligere Tønder amt, der ledes af fhv. førstelærer W. Leick, er ved at være afsluttet. Der mangler endnu et enkelt sogn.

Efter at landsarkivets fotografiske atelier er indrettet, bruges dette også af Historiske Samlinger, og fotoarbejdet her udføres af arkivbetjent Chr. Lind Petersen. Båndsamlingen er forøget med enkelte bånd, men der har ikke været midler til at iværksætte større arbejder her.

Fra amtskredsenes virksombed kan berettes, at medlemmerne af amtsudvalgene den 31. januar var indbudt til et møde på landsarkivet sammen med styrelsen. Formålet med dette møde, hvortil der var mødt 25 deltagere, 
var at udveksle ideer amtskredsene imellem, men især ville sekretæren, skoleinspektor Knud Kristensen gerne forelægge udkast til en hvervebrochure og til en ny, mindre vejledning for tillidsmændene. Der nedsattes et tremandsudvalg bestående af Knud Kristensen, Dorrit Andersen og Helge C. Jacobsen til at redigere vejledningen, og denne ny udformning har nu varet forelagt styrelsen til godkendelse. Der fremkom på madet forslag om nye emner som tillidsmæend. Fortegnelsen over disse er derefter revideret og suppleret og vil blive trykt i det kommende bind af Sønderjyske Arbøger. Der var stemning for, at sådanne orienteringsmøder gentages, evt. med to års mellemrum.

Inden for amtskredsenes regi har der $\mathbf{i}$ beretningsåret været arrangeret 10 møder med tilsammen ca. 830 deltagere, heri iberegnet de to møder, som Ảbenrå amtskreds arrangerer sammen med en lokal kreds i Varnxs sogn, og som samler mange deltagere. Indbefattet Historisk Søndag, der sidste sommer arrangeredes d. 4. august i Abenrå amt, har der på lokalt plan været 5 udflugter og byvandringer med tilsammen godt 400 deltagere. I alt har der, på trods af at museumsinspektør $\mathrm{H}$. Stiesdals foredragstourne måtte udskydes til april måned og derfor først tæller med $\mathrm{i}$ næste års statistik, været tale om en betydelig stigning $i$ tilslutningen til mødeaktiviteter, og interessant er det $\mathrm{i}$ øvrigt at bemærke, at interessen med årene kan svinge fra egn til egn. Medens Tønder og Haderslev amter tidligere lå som dem, der kunne møde med de største tal, er det nu Abenrå og Sønderborg. En forklaring på disse svingninger kan, når bortses fra vejr og vind, næppe gives.

Den såkaldte store egnsvandring fandt sted lørdag d. 6. september, og målet for turen var Sild, hvor universitetslektor i Kiel, dr. Ole Harck fortalte om arkæologiske udgravninger foretaget på øen og viste os nogle af fundene ved Arksum. Endvidere besås Kejtum kirke og museerne i Kejtum. Udflugten, der var arrangeret af et udvalg bestående af Knud Kristensen, Inger Bjorn Svensson og H. Lildholdt, samlede et deltagerantal på 287. Alt $\mathrm{i}$ alt har altså 1500 deltaget $\mathrm{i}$ møder og udflugter.

Arkivar Jørgen Witte har ligesom sidste år ledet et vejledende kursus $\mathrm{i}$ slægtshistorisk arbejde med et deltagerantal på 20. Et lignende kursus vil blive søgt oprettet til efteråret.

Skal man søge at sammenfatte beretningen om arbejdet i Historisk Samfund $\mathrm{i}$ det forløbne år $\mathrm{i}$ nogle få ord, kan det vel formuleres i retning af, at det har været et jæunt godt år. Sønderjyske Ärbøger og Sønderjysk Månedsskrift er på grund af prisudviklingen udkommet $i$ et lidt mindre omfang, end redaktionerne kunne have onsket sig, medens der er udsendt en bog både $\mathrm{i}$ skriftrækken og $\mathrm{i}$ serien Sønderjyske Levnedsløb, tilsammen 1035 s., hvortil kommer, at flere bøger er klar til udgivelse $i$ det kommende år. De mere folkeligt kulturelle aktiviteter, som ikke er de mindst vigtige, har vundet god og stigende tilslutning fra medlemskredsen.

Alt $\mathrm{i}$ alt er det en ganske betydelig virksomhed, der udfolder sig inden for Historisk Samfund for Sønderjylland, og denne virksomhed havde hel- 
ler ikke kunnet holdes $\mathrm{i}$ gang, såfremt foreningen ikke havde modtaget støtte såvel af offentlige som private midler. Der skal ved en lejlighed som denne lyde en tak til kulturministeriet, Dansk Kultursamfund og Lundtoft kommune, men først og fremmest til Sønderjyllands amtskommune for god støtte til flere af vore gøremål. Også til Fabrikant Mads Clausens Fond og Rislumfonden skal der lyde en hjertelig tak for modtaget stotte til udgivelser. Det er glædeligt, at foreningen nyder en sådan tillid hos offentlige og private institutioner, at vi takket være økonomisk støtte derfra kan på̀tage os betydningsfulde udgivelser og andre arbejdsopgaver. Denne tillid bør vi tilstrabe at bevare.

Efter formandens beretning aflagde kassereren, fhv. bankdirektør H. Lildholdt det reviderede regnskab (jvf. omstående). Gustav Auring onskede forklaring på et par poster, som kassereren redegjorde for, hvorefter såvel beretning som regnskab blev enstemmigt godkendt.

På valg var Peter Kr. Iversen, som blev genvalgt med akklamation. Under eventuelt takkede formanden den afgåede amtsformand for Åbenrå amtskreds, museumsinspektør Holger Jacobsen for et mangeårigt godt arbejde inden for Historisk Samfund. Dernæst meddelte formanden, at næste årsmøde vil blive afholdt i Sønderborg amtskreds på Sundeved Forsamlingsgård, og at Historisk Søndag, hvis tilrettelæggelse Haderslev amtskreds står for, afholdes den 1. august. Egnsvandringen vil blive afviklet den 11. september og gå til Sydslesvig.

Rektor Knud Fanø omtalte vanskelighederne ved at indhente beretninger fra museer $\mathrm{m}$. v. Da ingen flere ønskede ordet, sluttede dirigenten årsmødet. Efter kaffebordet holdt docent, dr. theol. A. Pontoppidan-Thyssen foredrag om Brødremenigheden $i$ første halvdel af det nittende århundrede. Årsmødet sluttede med, at museumsinspektør $\mathrm{H}$. Neumann ledede en byvandring gennem Christiansfeld med besøg på museerne, medens Christiansfelds viceborgmester, fru Ilse Søgaard foreviste kirkegården „Gudsager «. 


\section{Regnskab for året I. april 1975 til 31. marts 1976}

Indtagter:

Beholdning pr. 1.4.75 . 245.348,49

Medlemsbidrag $\ldots \ldots \ldots \quad 78.530,58$

Salg af skrifter ...... $50.400,60$

Sonderjysk Månedsskrift:

abonnementer,

annoncer $\ldots \ldots \ldots \ldots . \quad 26.119,65$

tilskud .......... 20.000,00

Andre tilskud ....... $63.823,00$

Renter .......... 22.217,36

Kr. $506.439,68$
Udgifter:

Sønderjyske Årbøger ... $\quad \mathbf{6 2 . 2 6 5 , 5 7}$

Skrifter ............ 63.353,01

Sdrj. Månedsskrift ..... $95.234,00$

Kontorhold ......... 7.792,88

Købt skrivemaskine .... $4.016,38$

Lonninger $\ldots \ldots \ldots \ldots \ldots \quad 47.525,48$

Møder o.1. .......... 6.643,11

Reprasentation $\ldots \ldots \ldots$ 4.181,27

Forsikringer $0.1 . \ldots \ldots \ldots \quad 1.847,40$

Bidrag til amtskredsene . $\quad 4.400,00$

Kontingent S.L.F. ..... $3.122,40$

Egnsvandring $\ldots \ldots \ldots \ldots \quad 1.153,45$

Historisk Sendag $\ldots \ldots \quad 1.584,70$

Moms ........... $1.834,00$

Porto $\ldots \ldots \ldots \ldots \ldots \ldots \quad 3.540,95$

Diverse .......... $\quad 3.119,48$

Beholdning pr. 31.3 .1976 . 194.825,60

Kr. $506.439,68$

\section{Status pr. I. april 1976}

\section{Aktiver:}

Beholdning $\ldots \ldots \ldots \ldots 194.825,60$

Udestående for salg .... $3.000,00$

Tilgodehavende moms .. $1.687,44$

Underskud

ovf. til naste år ..... 4.651,18

Kr. $204.164,22$

\section{Passiver:}

Ingrid Fondet f. Sdj. . . 21.301,09 Henlagt til:

Billedv., bd. II og IV .. 147.265,03

Sdj. Historikere ....... 20.697,76

Rømø (Thade Petersen) .. $\quad 10.000,00$

Egnsvandringsfond ..... 4.900,34

Kr. 204.164,22

Abenrå, den 22. april 1976.

\section{H. Lildboldt}

Foranstående regnskab har vi revideret og fundet i overensstemmelse med bilag, giro- og bankkonti.

Åbenrå, den 30. april 1976 .
Sv. Lyck
C. O. Henningsen

NB.: For abonnement på Sønderjysk Månedsskrift er der i april måned indgået kr. $51.168,00$. 


\section{Tillæg til medlemsfortegnelsen}

Efterfølgende supplement til den i årene 1955 til 1975 offentliggjorte medlemsfortegnelse for Historisk Samfund for Sønderjylland medtager som i de foregående år $\mathrm{i}$ afgangslisten kun de afdøde medlemmer, hvis død er kommet til vort kendskab, medens tilgangslisten omfatter alle nye medlemmer $i$ alfabetisk rækkefolge.

Pr. 31. marts 1976 udgør medlemstallet 2611, der fordeler sig på Sønderjylland og det øvrige land samt udlandet som følger:

Haderslev by ............. 170

Haderslev amt ........... 299

Sønderborg by $\ldots \ldots \ldots \ldots \ldots .83$

Sønderborg amt .......... 165

Tønder by $\ldots \ldots \ldots \ldots \ldots \ldots \ldots 126$

Tønder amt $\ldots \ldots \ldots \ldots \ldots \ldots 252$
Ảbenrå by $\ldots \ldots \ldots \ldots \ldots \ldots 254$

Ảbenrå amt ............. 278

Sydslesvig .............. 182

Storkøbenhavn $\ldots \ldots \ldots \ldots \ldots 278$

$\varnothing$ vrige Danmark .......... 489

Udlandet ............. 35

\section{Afgang ved død}

Andersen, P. Obeling, *Virkelyst«, Brøns

Blomgren, P., sparekassedirektør, Nordborg

Carstens, Karen Margrethe, lektor, Kolding

Christensen, Marie, cand. theol. \& mag., Kolding

Due, Osvald, lærer, Hove

Fink, Haakon, gårdejer, Brændstrup, Gram

Frydkjær, Cæthe, fru, Abenrå

Gadeberg, P., pastor, Logumkloster

Hansen, Johannes J., Ellehus

Hansen, Martin N., forfatter, Odense

Hansen, Paul-Erik, Roust
Jessen, Knud, professor, dr. phil., Virum

Korse, August, forretningsfører, Broager

Kring, Karen, lektor, København Lyck, P. K., direktør, Radding

Matthiesen, Poul M., gårdejer, Randerup

Møller, Olav, farmaceut, Ảbenrå

Moller, Sven Åge, kontorchef, Gråsten

Nissen, Anton, førstelærer, Lovrup

Nissen, Søren, gårdejer, Harres

Petersen, Johanne, fru, Bylderup

Petersen, P. J., arkitekt, Tønder

Strømming, Marta, fru, Åbenrå

\section{Tilgangsliste}

Andersen, Aage, pens. togfarer, Padborg

Bille, Bent, lærer, Broager

Blom, Hans Chr., Lunden

Brink, Jan Kaare, øjenlæge, Kolding

Christoffersen, Jytte Lis, Utholm

Clausen, Jorgen, Gråsten
Conradsen, Arthur, Åbenrå

Conradsen, Christian, revisor, Ảbenr $\not ̊$

Dalgaard, G., pens. stationsforst., Ȧbenrå

Debel, Niels, prokurist, Bov

Dirksen, Karen M., tandlæge, Ảbenrå 
Ebbesen, Martin, ingenier, Haderslev

Frederiksen, Niels, Ole, højskolelærer, Jaruplund

From, E., Århus

Fromm, Thomas, gårdejer, Hejsager

Frydkjær, Henry, fuldmægtig, Redovre

Hansen, Erik, bankdirektor, Flensborg

Hansen, Heinrich, kommuneingeniør, Jels

Hansen, Knud Aage, lærer, Haderslev

Hansen, Meta Kragh, Nybøl

Hansen, Peter Keller, stud. mag.,

Ãrhus

Holm, Jens, rentier, Skodborg

I. D. E., København

Jacobsen, Peter, direktør, Gentofte

Jansen, Folkert, direktør, A benrฉ̊

Jensen, Ingeborg, fru, Viby J.

Jessen, Ernst Helmuth, elektromester, Lak

Johansen, Arne P., Brønshøj

Johansen, Esther, fru, Gråsten

Johansen, Marius, lærer, Vrå

Johnsen, H. O., skoleinspektør, Egernsund

Jørgensen, Eskild, lærer, Felsted

Kolding gymnasiums bibliotek, Kolding

Lauritsen, Inge-Lise, fru, Ả benrå

Lauritsen, Nis, Varnzes

Lausten-Thomsen, H. P., stud. theol., Vejle

Lildholdt, Mads J., Løjtkirkeby

Loff, Gerda, fru, Hostrupskov

Ludvigsen, Carl Aastrup, afdelingschef, Brabrand
Lydiksen, Hans, købmand, Errested, Haderslev

Madsen, Magnus, kommunaldirekter, Virum

Nielsen, Astrid Koldby, Holte

Nielsen, Gunhild, Langå, Fyn

Nielsen, Hans W., bibliotekar, Tonder

Norgaard-Beth, Henrik, Tonder

Olesen, Theodor, gårdejer, Skovbymark

Olsson, S. E. Barner, konservator, Ảbenrå

Pedersen, Erling Bundgaard, stud. arch., Århus

Pedersen, John H., Sxdding

Petersen, Chr., provisor, Glostrup

Petersen, Erik Broe, Frøslev

Petersen, H. H., Kruså

Rasmussen, Th., fhv. overlarer, Horsens

Riis, Folmer, lærer, Egebjerg

Schmidt, Jensine, fru, Ảbl

Schwarz, Gunnar Th., adjunkt, cand. mag., Sønderhav

Skøtt sen., Hans, gårdejer, Haderslev

Steppat, Ortrud, fru, Slesvig

Sørensen, H. E., lærer, Skærbxk

Thems Boghandel, Horsens

Thomassen, Kjestine, fru, Åbenrå

Thyssen, Karen, fru, Kastrup

Tresselt, Wolfgang, Kronshagen

Wegener, Henrik, adjunkt, Sønderborg

Wind, C. H., togbetjent, Vejle

Wolf, Jes, telegrafmester, A benrå

\section{Fortegnelse over medlemmer af amtsudvalgene og tillidsmænd for Historisk Samfund for Sønderjylland}

\section{Haderslev amtskreds}

Amtsudvalget:

Kresten Hansen, Vamdrupvej 3, Skodborg, 6600 Vejen, formand tlf. 848335
Chr. Madsen, skatteinspektor, Tranevej 20, 6500 Vojens

J. Svane, skoleinspektør, Aller, 6070 Christiansfeld 
Søren Rasmussen, gdr., Hygumskov, 6630 Rødding

Helge C. Jacobsen, skolekonsulent, Astrupvej 310, 6100 Haderslev

Anker Eriksen, gdr., Brunbjerg, Halk, 6100 Haderslev

\section{Tillidsmend:}

Haderslev by

Olav Christensen, socialinspektør,

Storegade $81^{2}, 6100$ Haderslev

H. V. Gregersen, studielektor, dr. phil.

Dronning Alexandrinesvej 2,

6100 Haderslev

\section{Agerskov sogn}

Troels Refslund Poulsen, gdr.,

Bovlund, 6535 Branderup J.

\section{Aller sogn}

Erik Boesen, gdr., Stenbjerg, 6100 Haderslev

Jorgen Svane, skoleinspektør, Aller, 6070 Christiansfeld

\section{Bevtof sogn}

M. Sandholdt, bygmester, 6541 Bevtoft

Bjerning sogn

Hans Lydiksen, købmand, Errested, 6100 Haderslev

\section{Branderup sogn}

Arne Fog, førstelærer, 6535 Branderup J.

\section{Christiansfeld flekke}

J. C. Hjort-Petersen, overlærer, Birkevej, 6070 Christiansfeld

\section{Fjelstrup sogn}

Hans Chr. Skett, gdr., Fjelstrup, 6100 Haderslev

\section{Fole sogn}

Ellen Lund, frue, Fole, 6510 Gram

\section{Frørup sogn}

Peter Fink, forpagter, Frorup, 6130 Stepping
Gram sogn

Steen Christiansen, provst, 6510 Gram

Kirsten Friis, frue, Solvej, $6510 \mathrm{Gram}$

Grarup sogn

Thomas Fromm, gdr., Grarupgård, Grarupvej 24, Hejsager, 6100 Haderslev

Halk sogn

Anker Eriksen, gdr., Brunbjerg, Halk, 6100 Haderslev

Hammelev sogn

H. J. Gram-Hansen, civilingeniør, Hasselvej 18, Hammelev, 6500 Vojens

Hierndrup sogn

Aksel Gyldenkærne, førstelærer, Hjerndrup, 6070 Christiansfeld

\section{Hjerting sogn}

Jes Friis, gdr., Hjerting, 6630 Rødding

Hoptrup sogn

Catharine Rasmussen, fru proprietær, Hovgård, Hoptrup Hovedgade 120, 6100 Haderslev

\section{Hygum sogn}

Søren Rasmussen, gdr., Hygum, 6630 Rodding

\section{Jegerup sogn}

Laurids Aalling, konsulent, Selskær, 6500 Vojens

Jels sogn

Heinrich Hansen, kommuneingeniør, Mariegård, Jels, 6630 Rødding

\section{Lintrup sogn}

Johanne Jørgensen, fru forpagter, prastegården, Lintrup, 6630 Rodding

\section{Magstrup sogn}

E. Dalberg, pastor emeritus, Magstrup, 6572 Simmersted

Mads Sohl, gdr., Ringtved, 6500 Vojens 
Moltrup sogn

Hans Skøtt, gdr., senior, Rougstrupvej 35,6100 Haderslev

\section{Nustrup sogn}

Hans Jensen, gdr., Bæk, 6500 Vojens

Oksenvad sogn

Mads Otte, gdr., Stursbølgård, 6560 Sommersted

\section{Rødding sogn}

P. P. Staurup, overlærer, Rytterdam 12, 6630 Rødding

Skodborg sogn

$\mathrm{Kr}$. Hansen, frue, Vamdrupvej 3, Skodborg, 6600 Vejen

P. Otte, Gejlager, 6600 Vejen

\section{Skrave sogn}

H. Mathiesen, mejeribestyrer, Skrave, 6600 Vejen

H. Kloppenborg-Skrumsager, fru, Københoved, 6600 Vejen

Skrydstrup sogn

Chr. Madsen, skatteinspektør, Tranevej 20, 6500 Vojens

Sommersted $\operatorname{sog} n$

P. Lauridsen, forsikringsinspektør, 6560 Sommersted

Starup sogn

Hammer Sørensen, kaptajn, Starup Skovvej 1, 6100 Haderslev

\section{Stepping sogn}

Erik Oksbjerg, gdr., Anderupgård, 6070 Christiansfeld

Tirslund sogn

Jensigne Schmidt, frue, Ảbøl, 6520 Toftlund
Toftlund sogn

Hilmar Madsen, ingeniør, Rolighedsvej 14,6520 Toftlund

Tyrstrup sogn

Erik Mylin, skoleinspektør, Kristian VII's Vej, 6070 Christiansfeld

Vedsted sogn

Signe Lund, frue, Vedisted, 6500 Vojens

\section{Vilstrup sogn}

Frede Scherrebeck, gdr., Sdr. Vilstrup, 6100 Haderslev

Vojens sogn

T. Holm, sognepræest, Præstegårdsvej 4,6500 Vojens

Vonsbak sogn

Erik Krebs Lange, lærer, Katrinehøj 12, Vonsbæk, 6100 Haderslev

Øsby sogn

Helga Sørensen, gdr., Hajstrup, 6100 Haderslev

Øster-Lindet sogn

Hans Skøtt, Mojbøl, gdr., $6533 \varnothing$ ster-Lindet

Astrup sogn

Niels Åge Madsen, driftsleder, Ladegård, 6100 Haderslev

og af »de 8 sognex, der siden 1970 er en del af Christiansfeld kommune:

Hejls sogn

Klestrup, gdr., Kær Mølle, Vejstrup sogn, 6070 Christiansfeld

\section{Åbenrå amtskreds}

Amtsudvalget:

Poul Andersen, filialdirektør, Munkeladen, Rinkenæs, 6300 Gråsten, formand, tlf. 658244
Ib Andersen, lærer, Lindealle, Varnæs, 6200 Ảbenrå

Urban Schrøder, sogneprast, Varnæs, 6200 Å benrå 
H. C. Bang, overlærer, Nyvej 27, Bov, 6330 Padborg

Senius Tiedemann, gdr., Stenhøj 6552 Hovslund

\section{Tillidsmend:}

Adsbol sogn

Leif Burmeister, lærer, Østerbakken 9, Adsbøl, 6300 Gråsten

\section{Bedsted sogn Jørgen Clausen, handelsmand, Sivkrovej 16, Bedsted Lø, 6252 Bedsted}

\section{Bjolderup sogn}

Åge Jensen, pens. førstelærer, Todsbøl, 6392 Bolderslev

\section{Bov sogn}

H. C. Bang, overlærer, Nyvej 27, Bov, 6330 Padborg

H. F. Rohden, kriminalkommissær, Valdemarsgade 24, 6330 Padborg

\section{Egvad sogn}

Knud Fink, gdr., Østergård, Nr. Hostrup, 6230 Rødekro

\section{Ensted sogn}

Christian Th. Schmidt, skolelæge, Jakobsgård, Bygaden 41, Røllum, 6200 Åbenrå

\section{Felsted sogn}

J. H. Jensen, pens. førstelærer, Østergade, Felsted, 6200 Ảbenrå

\section{Gråsten sogn}

Vakant

\section{Hellevad sogn}

Peter F. Hansen, pens. førstelærer, Vestervænget 11 , Hellevad, 6230 Rødekro

\section{Hjordker sogn}

Arne Kindberg, gdr., Nybølgård, Hjordkær, 6230 Rødekro
Holbol sogn

P. J. Petersen, provst, Holbel, 6382 Tørsbøl

Karlo Berkjar Christensen, politiassistent, Holbøl, 6382 Tørsbø1

\section{Kliplev sogn}

Christian Jørgensen, skoleinspektør, Lillegade 10, Kliplev, 6200 Ảbenrå

\section{Kvers sogn}

F. Moller Lauridsen, sogneprast, Kværs Præstegård, 6382 Tørsbøl

\section{Løjt sogn}

Petrea Schmidt, frue, Løjt Kloster, 6200 Ảbenrå

\section{Rinkenes sogn}

Poul Andersen, filialdirekter, Munkeladen, Rinkenæes, 6300 Gråsten

\section{Rise sogn}

Bent Holsteen Jessen, gdr., Brunde, 6230 Rødekro

Uge sogn

Erik Schmidt, gdr., Olmersvold, Uge, 6360 Tinglev

\section{Varnes sogn}

Ib Andersen, lærer, Lindealle, Varnæs, 6200 Ảbenrå

Urban Schrøder, sognepræst, Varnæs, 6200 Ābenrå

\section{Øster Løgum sogn}

Senius Tiedemann, Stenhøj, Hovslund, 6230 Rødekro Jes Holdt, pens. førstelarer, Nørreskovvej 15, Genner, 6200 Åbenrå

\section{Abenrå købstad}

K. A. Flade, arkitekt, Langløkke 9, 6200 Abenrå

Holger Jacobsen, pens. fuldm., Vægterpladsen 1a, 6200 Ảbenrå 
Amtsudvalget:

Olav J. Bonefeld, gdr., Snogbak, 6400 Sønderborg, formand, tlf. 467130

J. P. Ditlefsen, skoleinsp., Langesø, 6430 Nordborg, sekretæer

Hans G. Bojsen, studielektor, Alssundvej 54, 6400 Sønderborg

Age Rasmussen, viceskoleinspektør, Solskrænten 15, 6310 Broager

Christian Speggers, gdr., Miang, 6400 Sønderborg

\section{Tillidsmand:}

Asserballe sogn

Chr. E. Christensen, gdr., Sxdmosegård, Asserballe, 6440 Augustenborg

Augustenborg flokke

Hans Lind, fuldmægtig, Mosevænget 9, 6440 Augustenborg

Broager sogn

Age C. Rasmussen, viceskoleinspekter, Solskræenten 15, 6310 Broager

Dybbol sogn

M. Storgård, sognepræst, Dybbel, 6400 Sønderborg

Egernsund sogn

Thorvald Bech Nielsen, overlærer, Storegade 71, 6320 Egernsund

Havnbjerg sogn

J. P. Ditlefsen, skoleinspektør, Langese, 6430 Nordborg

Horup sogn

Peter Hell, husmand, Havemose 2, Lambjerg, 6400 Sønderborg

Ketting sogn

H. Damgård, sogneprest,

Ketting Præstegård, 6440 Augustenborg

Kegnes sogn

Jens Bladt, fhv. sognerådsformand, Bøgehoved, 6474 Skovby, Als
Lysabild sogn

Søren Fransen, sognepræst, Iysabild Prastegård, 6474 Skovby, Als

\section{Nordborg flekke}

Nordborg landsogn

Herbert Wilhelmsen, overlærer, Apotekervænget 22, 6430 Nordborg

\section{Notmark sogn}

Gunnar Rasmussen, forstander, Danebod Højskole, Fynshav, 6440 Augustenborg

Nybol sogn

G. Weitling, adjunkt, dr. theol., Nybel, 6400 Sønderborg

Oksbol sogn

Niels Lausten, købmand, Broballe, 6430 Nordborg

Sottrup sogn

Olav J. Bonefeld, gdr., Snogbrk, 6400 Sonderborg

\section{Svenstrup sogn}

Mogens Dyre, ingeniør, Danfoss; 6430 Nordborg

\section{Sonderborg kobstad}

Hans G. Bojsen, studielektor, Alssundvej 54, 6400 Sønderborg Jørgen Sletrebo, museumsinspektør, Slottet, 6400 Sønderborg

Tandslet sogn

Helga Hansen, fru, Tandsgård, 6473 Tandslet

Ulkebol sogn

Anne Thomsen, larerinde, Rosenhaven 15, 6400 Senderborg

Egen sogn

Hans Aagaard, Mosevej 11, Guderup, 6430 Nordborg

Ullerup sogn

K. T. Jensen, larer, Bakkensbro Skole, Avnbøl, 6400 Sønderborg 


\section{Tønder amtskreds}

Amtsudvalget:

Viggo Gregersen, fuldmægtig,

Højervej 23, Møgeltønder, 6270 Tønder, formand, tlf. 748252

S. N. Christensen, skoleinspektør, kasserer og sekretær, Ravsted, 6372 Bylderup Bov, tlf. 647104

Knud Nielsen, gdr., Visby, 6270 Tønder

Svend Oksen, advokat, Skolegade 1, 6780 Skærbæk

Mary Bahne Nicolaisen, fru, Østerholm, 6360 Tinglev

\section{Tillidsmand:}

Tonder by og landsogn

W. Christiansen, fhv. viceskoleinspektør, Brorsonsvej 37, 6270 Trnder

Abild sogn

Vakant

\section{Arrild sogn}

Hans Schmidt, gdr., Sandet, Arrild, 6520 Toftlund

\section{Ballum sogn}

Olav Nissen, gdr., Bådsbøl-Ballum, 6780 Skærbæk

\section{Brede sogn}

Knud Nielsen, viceskoleinspektør,

Toften 4, 6261 Bredebro

\section{Brøns sogn}

Kirsten Thaisen, fru, Præstegården, Brøns, 6780 Skærbak

\section{Burkal sogn}

Mary Bahne Nicolaisen, fru, Burkal, 6360 Tinglev

\section{Bylderup sogn}

Tage Madsen, lærer, Bylderup skole, 6372 Bylderup Bov

\section{Daler sogn}

Kr. Danielsen, gdr., Gærup, 6270 Tonder
Døstrup sogn

J. Hjortskov Larsen, skoleinspektør, 6775 Dostrup S.

\section{Emmerlev sogn}

Hans Toft, gdr., Emmerlev, 6280 Højer

Hierpsted sogn

C. Brodersen, fhv. bagermester, Hjerpsted, 6280 Højer

Hostrup sogn

Maren Friedrichsen, fru, Rørkær, 6270 Tonder

\section{Hviding $\operatorname{sog} n$}

Vakant

Hojer flakke

Tage Bundgård, boghandler, Storegade 21, 6280 Højer

Højer landsogn

Iver Kristensen, bestyrer, Rudbølgård, $6280 \mathrm{Højer}$

Hojrup sogn

Chr. Sørensen, lærer, Vestergade 4, Arnum, 6510 Gram

Hojst sogn

Jens Bendorff, landpost, Øster Højst, 6240 Logumkloster

Løgumkloster flakke og landsogn Frede Gotthardsen, lærer, Ringgade 15, 6240 Logumkloster

Mjolden sogn

K. N. Laursen, sognepræst, Mjolden, 6775 Dostrup

Møgeltønder sogn

Viggo Gregersen, fuldmægtig, Højervej 23, Møgeltønder, 6270 Tønder

Nr. Løgum sogn

Anna Buhl, sygeplejerske, Løgumgårde, 6240 Løgumkloster 
Ravsted sogn

S. N. Christensen, skoleinspektør, Ravsted, 6372 Bylderup Bov

\section{Randerup sogn}

Søren Schmidt, fuldmægtig, Randerup, 6261 Bredebro

Rejsby sogn

Poul A. Pedersen, gdr., Rejsby, 6780 Skxrbæk

\section{Roager sogn}

Vakant

\section{Rømø sogn}

Christian Jørgensen, sognepræst, 6791 Kongsmark

\section{Skast sogn}

Peter Terkelsen, gdr., Skast, 6780 Skærbæk
Skerbek sogn

Svend Oksen, advokat, Skolegade 1, 6780 Skxrbxk

Spandet $\operatorname{sog} n$

Vakant

Tinglev sogn

Esther Feddersen, bibliotekar, Nørreagervej 6a, 6360 Tinglev

\section{Ubjerg sogn}

Vakant

Visby sogn

K. Schmidt Nielsen, skoleinspektør, Visby, 6270 Tønder

Vodder sogn

H. E. Andreasen, skoleinspektør, Gartnervej 7, 6780 Skxrbæk

\section{Amtsudvalget:}

Lars Schubert, fhv. kontorchef, Friesische Str. 29, D-239 Flensborg, formand, tlf. 0094946120240

Anna Schroder, forstander, Marienhölzungsweg 66, D-239 Flensborg, kasserer

Flemming Møller, pastor, D-2253 Tenning, Herrengraben 3

\section{Sydslesvig}

Paul Tappe, pastor, D-2262 Lxk,

Osterstr. 5

Johann Runge, studielektor, dr. Dansk Centralbibliotek, Nørregade 59, D 239 Flensborg

Alex Herz, journalist, Hornbrunnen 8 , D-2380 Slesvig 


$$
\text { - }
$$




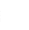



